\title{
AVALIAÇÃO CLÍNICA DOS EFEITOS DA DISTORÇÃO RADIOGRÁFICA NO POSICIONAMENTO E CLASSIFICAÇÃO DOS TERCEIROS MOLARES INFERIORES.
}

LUÍS FERNANDO DE MELLO SANT'ANA

Dissertação apresentada à Faculdade de Odontologia de Bauru, da Universidade de São Paulo, como parte dos requisitos para a obtenção do título de Mestre em Estomatologia.

(Edição Revisada)

BAURU

2002 


\section{AVALIAÇÃO CLÍNICA DOS EFEITOS DA DISTORÇÃO RADIOGRÁFICA NO POSICIONAMENTO E CLASSIFICAÇÃO DOS TERCEIROS MOLARES INFERIORES.}

LUÍS FERNANDO DE MELLO SANT'ANA

Dissertação apresentada à Faculdade de Odontologia de Bauru, da Universidade de São Paulo, œmo parte dos requisitos para a obtenção do título de Mestre em Estomatologia.

(Edição Revisada)

Orientadora: Prof ${ }^{\mathrm{a}}$. Dr ${ }^{\mathrm{a}}$. Ana úcia Álvares Capelozza

BAURU

2002 
Ficha Técnica

Luis Fernando de Mello Sant' Ana: Concepção original, redação e digitação. Ana Lúcia Álvares Capelozza: Orientação geral e revisão final.

Prof' Ema Maria Duarte: Vemáculo.

LTJ Editora Gráfica LTDA: Layout, formatação e impressão. José Roberto Pereira Lauris: Análise estatística.

Sant Ana, Luís Fernando de Mello

Sa59a Avaliação clínica dos efeitos da distorção radiográfica no posicionamento e classificação dos terceiros molares inferiores / Luis Femando de Mello Sant'Ana. - Bauru, 2002 .

xvii, 134 p. : il. ; $30 \mathrm{~cm}$.

Dissertação (Mestrado) - Faculdade de Odontologia de Bauru. USP.

Orientadora: Prof". Dr. Ana Lúcia Álvares Capelozza

Autorizo a reprodução total ou parcial, da referida Dissertação de Mestrado.

Luis Fernando de Mello Sant'Ana

Autor.

Aprovado pelo Comitê de Ética em Pesquisa desta Faculdade. 


\section{Luís Fernando de Mello Sant'Ana}

01 de maio de 1975

São Paulo - SP

$1995-1998$

$1999-2000$

2001

2002

Associações
Nascimento

Curso de Odontologia - Faculdade de Odontologia de Bauru da Universidade de São Paulo.

Estágio junto à Disciplina de Cirurgia da Faculdade de Odontologia de Bauru - USP.

Curso de Pós-Graduação em Estomatologia, em nível de Mestrado, na Faculdade de Odontologia de Bauru - USP.

Professor convidado do curso de aperfeiçoamento em Cirurgia Oral Menor pela FUNBEO.

APCD - Associação Paulista de Cirurgióes-Dentistas

SBPqO - Sociedade Brasileira de Pesquisa Odontológica

IADR - International Association of Dental Research 
When I grow up to be a man

Like my father was when I was young

I frope I can make fim so proud of me

Proud enough to call me fis son

We're all sons of our fathers

Sometimes I feel like mine

And I can fiear fim saying the things I say

Seems all tfings come around in time

(Pfil Collins - Son's of our Fatfiers)

Dedicatória 


\section{Dedicatória}

Aos meus pais Lourival e Felena e meu imäo Paulo Henrique. Por todos os sonfios compartifhados, por aqueles outros de que vocês abdicaram para a concretização do meu. Por todas as dificulfades que enfrentamos juntos, pois através delas conflecemos a força de nossa união. Pela formação do meu caráter, pelo modelo de integridade, dedicação, compaixão e amor.

Dedico a vocês este trabalfio

Do fillo e immão que ama vocês mais do que a própria vida. 
What would you do if I sang out of tune would you stand up and walk out on me Lend me your ears and I'll sing you a song I will try not to sing out of key

I get by with a Gutle fielp from my friends I just keep trying with a fittle fielp from my friends I want to get figh with my friends I just fold on with my friends

\section{Agradecimentos Especiais}




\section{Agradecimentos Especiais}

Aos meus etemos amigos de Americana, Alexandre, Rafael, Marcos, Luís Marceto e Guilherme. Nós nos confecemos desde o Jardin de Infância, caminfiamos juntos até o $3^{\circ}$ colegial. Apesar de cada um ir para lugares diferentes, em busca de seus sonfios, a amizade continuou crescendo dưante todos estes anos. Vocês estarāo sempre em meu coraçāo, em meus pensamentos e em minfias oraçōes. Adoro todos vocês!l!

Ao Jorge e à Deise ( $L T$ V Ed. Gráfica LTDM) que são meus tios adotivos, a convivência com vocês é sempre uma alegria para meu coração. O6rigado também pelo profissionalismo e respeito com o qual trataram este, que foi até agora, a maior conquista da minfua vida.

Ao colega de graduação, república, estágio e pós-graduação; meu grande amigo-imão, Femando Paganefi Machado Gigfio, o Jordy. Caminfiamos juntos desde 1995, sempre um ajudando o outro. Como não poderia ser diferente, sua ajuda foi fundamental 
Agradecimentos Especiais

na execução deste trabalfio; afinal de contas todas as cirurgias foram feitas com seu precioso auxifio. Obrigado pelas dicas profissionais, pessoais e principalmente pela fionra de poder considerar-me seu amigo.

Ao amigo e mestre Prof. Dr. Eduardo Sant'Ana. Vma amizade sólda e verdadeira, 6aseada em respeito múttuo se concretiza com o tempo. Devo a você minfia formação e sucesso profissional. Obrigado pela confianţa depositada em mim, e saiba que nunca wou desapontá-60. Tenfio orguffo de poder chamá-lo de professor. Que Deus continue ifuminando seu caminfio e de sua famifia.

Ao meu grande amigo Prof. Dr. Osny Femeira Ir. Sua dedicaçäo para com os alunos, a justiça com a qual os trata e sua seriedade são verdadeiros modelos que pretendo seguir em minfia cameira profissional. Sua honestidade e caráter, modelos para minfia vida. Todas as suas sugestões para este tra6alfo foram excelentes. Obrigado!

Я̀ minfia amiga, conselheira e orientadora Prof". Dr. Ana Lúcia Álvares Capelozza. Já nos identificamos um com o outro desde a graduação, tanto que fora nome de minfia tuma e coordenadora de nossa Jornada Científica. O carinfio com que sempre fui rece6ido, as criticas que me foram feitas e o confiecimento compartifhado fizeram-me tornar 
um ser fiumano methor. Com certeza você é uma das melthores pessoas que eu confieço. Minha etema gratidão e admiração.

Aos meus famifiares, em especial a minfuas outras "mães", minfia tia Regina e Inês. Sua ajuda, carittio e sorriso com que sempre me receberam eram um porto seguro que tinfia tas fioras de maior dificuldade durante minfia vida toda. Amo vocês!!!

Aos meus prinos Cássio, Andréia, Guto e Ana. Nosso convívio desde a infância, nossa amizade e uniāo sāo mais importantes para mim do que vocês podem imaginar. Adoro todos vocês!l!

Ao meu tio e padrinfio José Maria Rusconi, e meus queridos Vo Moacyr, Vó Lourdes e Vô Lourivah que estão junto de Deus, ofhando por mim e acompanfiando todos os meus passos. Vocês que durante a vida foram fonte de segurança e alegria para mim. Neste momento sei que estäo sorrindo e orguliosos por mim, mas sinto falta do somiso e do abrạ̧o de vocês. Tenfio muita saudade de todos vocês.

Aos engenfieiros Lourival de Sant'Ana Fiffo e Paulo Fenrique de Mello Sant ' Ana, pela dedicação no projeto do dispositivo utifizado nesta pesquisa. 
Leaving my family befind me

Not knowing what lay afiead

Waving goodbye, as I left them in tears

Remembering all we'd said

I looked to the sky, I offered my prayers

I asked Hin for guidance and strength

But the simple 6eliefs of a simple man

Lay in His fiands and on my fiead

(Genesis - Driving the Last Spike)

Agradecimentos 


\section{Agradecimentos}

Agradego a Deus, acima de tudo, por Sua Sa6edoria ao me guiar pela vida, por Seu amor nos momentos dificeis $e$, acima de tudo. pela generosidade de fazer passarem pela mintha existência pessoas as quais tive o priviégio e a fionta de confiecer.

À diretora da Faculdade de Odontologia de Bannu, Prof". Drt.

Maria Fidela de Lima Navarro.

Ao presidente da Comissão de Pós-Graduaçäo da Faculdade de Odontologia de Bauru, Prof. Dr. José Cartos Pereira.

Aos funcionánios do Departamento de Tstonatologia da Faculdade de Odontologia de Bannu, a Marifia, o Zezinfio, a Femanda, a Walderez, a Cris, a Josieli e a Camila. Obrigado pela presteza, carithio e profissionalismo. 
Aos colegas de pós-graduạ̧ão, o Cláudio, a Josi, a Nicole e o Flávio.

Estes dois anos foram inesquecíveis, obrigado!

Ȧs colegas do doutorado em Estomatologia, a Flavirfia, Mariela $e$ Luciana. O6rigado pelo apoio, amizade e experiêtcia transmitida.

Aos funcionários do Setor de Vrgência Odontológica da Faculdade de Odontologia de Bauru, a minfia segunda casa aqui na Faculdade, a Regina, a ELZa, a Alice e o Éduardo. Sem vocês ao meu lado seria difficil concluir este trabalfto.

Aos cinurgiōes-dentistas responsáveis pelo setor de Vrgência Odontológica da Faculdade de Odontologia de Bauru, Christiano e Mauro, pelo apoio incondicional para a realização deste trabaltho.

A todos os amigos que fiz durante o curso de Pós-Graduação. Foi um privifégio poder conviver com todos vocês em nossos passos inticiais. Espero que a distâtncia imposta pelas diferentes disciplinas que fizemos seja sempre menor do que a amizade forjada nesses 2 anos de contvivência. 
Ao Prof. Dr. Joäo Adolfo Caldas Navarro (in memoriam, por estar ao meu lado ensinando os primeiros passos numo à ciência durante a graduação.

Aos funcionários da Faculdade de Odontologia de Baure

Aos funcionánios da Biblioteca da Faculdade de Odontologia de

Bauru

Aos estagiários da Disciplina de Cinurgia da Faculdade de Odontologia de Bauru, o Marcelo, o César e a Érikga. Obrigado pela ajuda, pela disponibifidade e dedicaf̧ão com que sempre me atenderam.

A todos os professores que tive durante a minfia graduação e PósGradiação na Faculdade de Odontologia de Baunu. Levo um pouco de todos para tentar me tomar um 6otn professor. Espero que consiga ser importante na vida de alguém assim como foram importantes na minfia.

Aos meus amigos da XXXIV Turma. Que saudades!!!! 
Aos afunos de graduação da Faculdade de Odontologia de Bauru, por permitir que entrasse na vida de vocês com a mais nobre de todas as missões, a de ensinar. Aprendi com vocês muito mais đo que ensintei. Obrigado pela confiança e amizade.

Aos professores do Departamento de Estomatologia da Faculdade de Odontologia de Baunu, Prof. Dr. José Fumberto Damante, Prof. Dr. Luiz Eduardo Montenegro Cfitnelatto, Prof. Dr. Clóvis Marzola, Prof. Dr. Júlio de Araújo Gurgele Prof:. Dr Isabel Regina Fischer Rubira. Agradeço o confhecimento, a experiência transmitida e a amizade.

Aos pacientes que, gentifmente, concordaram em participar deste trabalho. 


\section{SUMÁRIO}

RESUMO ___ XV

1. INTRODUÇÃO ___ 1

2. REVISÃO DE LITERATURA____ 5

2.1 - Radiografias Panorâmicas ___ 6

2.1.1-Conceitos__ 6

2.1.2 - Distorção radiográfica e formação da imagem __ 10

2.2 - Cirurgia dos Terceiros Molares Inferiores ___ 19

2.2.1 - Indicações _ 19

2.2.2 - Incidência e prevalência___ 25

2.2.3 - Planejamento, posicionamento do terceiro molar e técnica cirúrgica__ 29

2.3- Siliconas de Adição____ 38

3. PROPOSIÇÃO ___ 40

4. MATERIAL E MÉTODOS____ 42

5. RESULTADOS _ _ 78

6. DISCUSSÃO ___ 91

6.1 - Prevalência da Posição dos Terceiros Molares ___ 94

6.2 - Variação de Classificação e Implicações Clínicas____ 96

6.3 - Distorção Radiográfica______ 102

7. CONCLUSÕES ___ 105

ANEXOS ___ 107

REFERÊNCIAS BIBLIOGRÁFICAS___ 118

ABSTRACT — 132 
RESUMO 


\section{RESUMO}

A qualidade da imagem radiográfica é de fundamental importância no planejamento cirúrgico de dentes não irrompidos.

A radiografia panorâmica é, sem dúvida, a mais utilizada, pois permite a visualização da maxila e da mandíbula em uma só tomada radiográfica, expondo o paciente a pequenas doses de radiação. Entretanto esta técnica resulta em imagens com distorções e diminuição dos detalhes inerentes ao processo de formação da imagem.

O objetivo deste estudo é avaliar a distorção na posição de terceiros molares inferiores, segundo a classificação de WINTER, em radiografias panorâmicas realizadas pelo aparelho Rotograph Plus® quando comparada às medidas realizadas em modelos de gesso, obtidos a partir de moldagens trans-cirúrgicas dos pacientes.

O estudo foi realizado a partir de radiografias panorâmicas de 14 pacientes com indicação de exodontia dos terceiros molares inferiores; durante as cirurgias foram realizadas moldagens com silicona de adição, após a exposição da coroa do dente a ser extraído. Foram confeccionados, então, 
modelos de gesso tipo IV, obtendo-se um total de 19 modelos. Após a realização das medidas nas radiografias e nos modelos de gesso, obtivemos os seguintes resultados: há uma diferença média entre a posição do terceiro molar na radiografia panorâmica e no modelo de gesso de 5,37 (desvio padrão 1,46 , valor máximo $9^{\circ}$ e mínimo $4^{\circ}$ ). Em teste "T" Student foi verificado que o ângulo formado na radiografia é maior que o formado nos modelos de gesso, com $\mathrm{p}<$ 0,05. A radiografia panorâmica sempre mostrou o dente em posição mesializada, quando comparado clinicamente.

Pode-se concluir que existe considerável distorção na posição dos dentes, resultado que pode influenciar o planejamento cirúrgico dos mesmos, considerando que uma das indicações do seccionamento do dente durante a cirurgia é sua inclinação, o que não invalida o uso da radiografia panorâmica como principal meio de diagnóstico e planejamento cirúrgico dos terceiros molares inferiores não irrompidos. 
1 - INTRODUÇÃO 


\section{1- INTRODUÇÃO}

É preconizado na literatura específica de cirurgia bucomaxilofacial que para o planejamento cirúrgico dos dentes não irrompidos, seja realizada uma radiografia panorâmica ${ }^{10,25,49,50,53,65}$.

Logo, para o planejamento desta cirurgia, é de fundamental importância que o cirurgião-dentista conheça as limitações impostas pelo método de formação de imagem desta radiografia. A radiografia panorâmica é obtida a partir de aparelhos que operam por um sistema rotacional, onde a fonte de raios $\mathrm{X}$ e o filme desenvolvem um movimento sincronizado, em sentido oposto, enquanto o paciente permanece imóvel 5, 8, 23, 34,76 .

A radiografia panorâmica tem como uma das principais vantagens a pequena dose de radiação ionizante a que o paciente é exposto e uma completa visualização do complexo maxilo-mandibular em uma única 
radiografia; porém nas suas desvantagens é que encontramos obstáculos para o correto planejamento cirúrgico dos terceiros molares. Dentre elas estão a falta de nitidez, formação de imagens fantasmas e, principalmente, a distorção de tamanho e posição dos objetos radiografados. A distorção é causada por planificar uma superfície tridimensional em uma imagem bidimensional 5, 8, 23, 34,76

Faz-se necessário, então, que os cirurgiões-dentistas conheçam o aparelho panorâmico em que são realizadas as radiografias de seus pacientes, pois há variações dos graus de distorção radiográfica entre os aparelhos ${ }^{8}$. Ao conhecer a magnitude das distorções causadas por determinados aparelhos durante a interpretação radiográfica, o profissional pode melhor avaliar a morfologia e estimar um posicionamento adequado do objeto estudado e suas relações com estruturas adjacentes.

O conhecimento das limitações da radiografia panorâmica torna-se imprescindível ao cirurgião-dentista para que este possa estabelecer medidas seguras, que propiciem um planejamento mais seguro e com menor probabilidade de surpreende-lo durante a cirurgia.

A partir de observações clínicas durante o atendimento dos pacientes encaminhados para extração dos terceiros molares nas clínicas de cirurgia do departamento de Estomatologia da FOB-USP, com o uso de 
radiografias panorâmicas recentes, foram constatadas variações nas posições dos terceiros molares inferiores durante as exodontias. 
2 - REVISÃO DE LITERATURA 


\section{2 - REVISÃO DE LITERATURA}

\section{1 - $\underline{\text { RADIOGRAFIAS PANORÂMICAS }}$}

\section{$\underline{2.1 .1-\text { Conceitos. }}$}

UPDEGRAVE $^{69}$, em 1966, conceitua a radiografia panorâmica como resultado de um método de exame por imagem que utiliza o princípio da laminografia em superfície curva, no qual estruturas anatômicas dentro de um plano seccionado são registradas em um filme radiográfico, enquanto que estruturas fora deste plano aparecem borradas, não interferindo na radiografia final.

SÄMFORS; WELANDER ${ }^{58}$, em 1972, afirmam que a radiografia panorâmica é composta de uma série de fragmentos de imagens, que vão sendo sucessivamente projetados em um filme em movimento.

McDAVID et $\mathrm{al}^{38}$, em 1984, conceitua a perda de nitidez radiográfica absoluta como a duração total da projeção do feixe de raios $\mathrm{X}$ incidindo perpendicularmente sobre o filme radiográfico, e considera como 
perda de nitidez radiográfica relativa, a divisão da perda de nitidez radiográfica absoluta pelo fator de ampliação da profundidade do objeto onde está situado.

O autor ainda afirma que os dois fatores acima citados, quando relacionados, resultam em uma imagem borrada nas radiografias panorâmicas; enquanto a imprecisão absoluta descreve os efeitos do borramento pelo movimento do filme, a imprecisão relativa normaliza este efeito no plano do objeto.

A radiografia panorâmica é um método prático que permite o exame radiográfico de toda a região dento-alveolar e estruturas adjacente de interesse em um único filme $3,5,8,23,34,74$.

FREITAS; TORRES ${ }^{23}$, em 1988, ALVARES; TAVANO 5 , em 1993, afirmam que a radiografia panorâmica como uma tomografia, pois seu método de formação de imagem é feito de pequenos cortes ou áreas seccionadas, sem superposições das estruturas situadas acima ou abaixo do corte; onde as estruturas que não se encontram no plano de corte da radiografia apareceriam sempre borradas (Figura 2.1). 


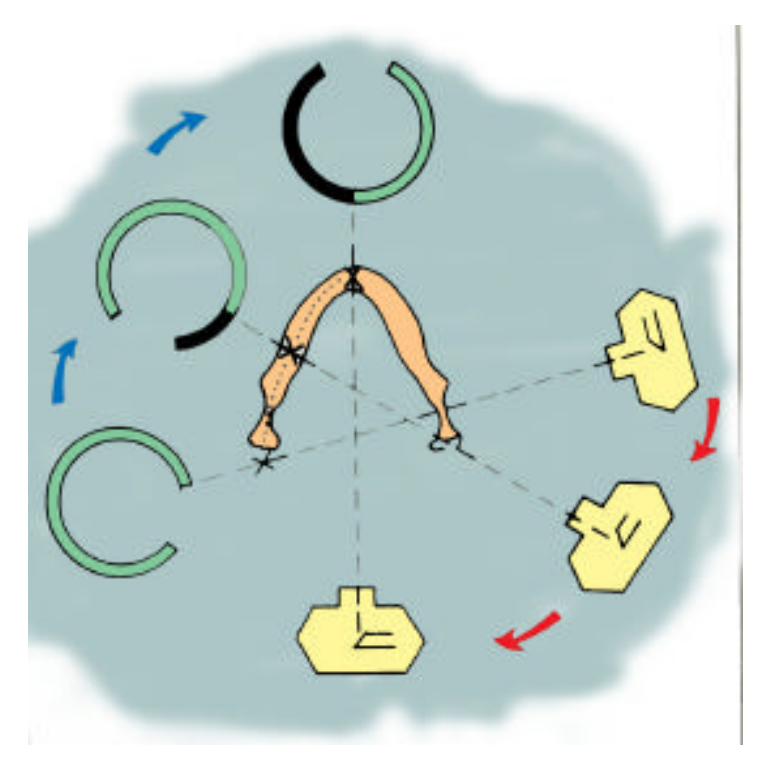

Figura 2.1 - Esquema de funcionamento de um aparelho panorâmico e como é formada a imagem radiográfica.

WELANDER; TRONJE; McDAVID ${ }^{74}$, em 1989, descreveram os princípios gerais da formação da imagem radiográfica panorâmica. Estes autores afirmam que este processo de formação é único, pois o foco da projeção das dimensões horizontais é diferente do foco da projeção das dimensões verticais.

ALVARES; TAVANO5, em 1993, afirmaram que a radiografia panorâmica utiliza os princípios da laminografia em superfície curva, em que estruturas anatômicas que devem ser visualizadas são registradas em um plano selecionado, enquanto que partes interferentes são borradas e não discerníveis no filme. Os autores consideram que a radiografia panorâmica proporciona subsídios adequados para a maioria dos procedimentos de cirurgia bucal e enfatizam que a simplicidade de operação, a ampla cobertura da área 
examinada e as baixas doses de radiação são algumas das vantagens da radiografia panorâmica. Ainda explicam os princípios de formação da imagem na radiografia panorâmica, em função da movimentação da fonte emissora de raios $\mathrm{X}$ e do filme radiográfico. Baseados nos princípios da formação da imagem radiográfica, puderam citar como principal desvantagem da radiografia panorâmica a falta de nitidez e a distorção das estruturas. 


\subsection{2 - Distorção radiográfica e formação da imagem}

De acordo com WELANDER ${ }^{74}$, em 1989, PATEL; MASON-HING ${ }^{47}$, em 1984, ÁVILA ${ }^{8}$, em 1996, FREITAS; ROSA; SOUZA ${ }^{23}$, em 1988, CASATI; TAVANO ${ }^{5}$, em 1993; as imagens obtidas a partir das técnicas panorâmicas (ortopantomografia e elipsopantomografia) apresentam distorções. Segundo estes autores, estas distorções referem-se às ampliações no sentido vertical e horizontal e são dependentes de cada tipo de aparelho (forma, espessura de corte e angulação dos raios X). Estes autores ainda citam que existem fatores externos, além dos inerentes à técnica radiográfica, que podem afetar a qualidade da imagem da radiografia panorâmica, destacando: assimetria dos arcos dentários, posicionamento incorreto do paciente e falta de cooperação deste durante a realização do exame.

SÄMFORS; WELANDER ${ }^{58}$, em 1972, afirmaram que um movimento do paciente durante a tomada radiográfica pode afetar a interrelação entre os fragmentos da formação da imagem da radiografia panorâmica, causando uma distorção geral da composição da imagem. Mostraram que a direção, extensão e duração do movimento afetariam de forma diferente a radiografia panorâmica. Exemplificaram com a realização de um movimento 
abrupto de um paciente durante a realização de uma radiografia panorâmica resultando em uma simulação de fratura de maxila.

\section{LUND; MASON-HING ${ }^{37}$, em 1975, demonstraram as} implicações clínicas da variação dos aparelhos panorâmicos (foco circular e elíptico). Mostraram que, quando há movimento do paciente durante a tomada radiográfica ou mal posicionamento do mesmo, a formação da imagem do arco dentário é afetada, pois algumas regiões podem sair do plano de corte do aparelho, comprometendo o diagnóstico (Figura 2.2). Os autores complementam ainda que a rotação do eixo do mento tende a mover os dentes posteriores para fora do plano de corte do aparelho.

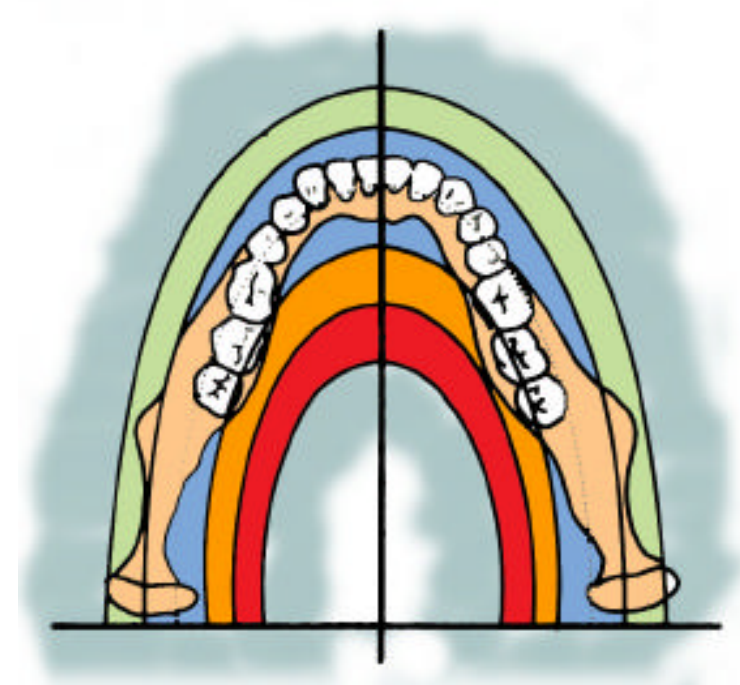

Figura 2.2 - Esquema dos diferentes planos de corte possíveis de se conseguir com um elipsopantomógrafo.

AZAZ; SHTEYER; PIAMENTA ${ }^{9}$, em 1976, determinaram a importante correlação entre as radiografias panorâmicas pré- 
operatórias e os achados anatômicos relacionados aos terceiros molares inferiores e às seqüelas pós-operatórias. Em um estudo feito com 200 pacientes, $60 \%$ dos terceiros molares apresentavam radiograficamente relação com o canal mandibular, sendo que apenas $19 \%$ dos dentes apresentavam realmente relação anatômica constatada na cirurgia. Os outros $41 \%$ simulavam esta relação devido à superposição da imagem na radiografia panorâmica. Os terceiros molares que mais tiveram relação com o canal mandibular foram os que ocupavam uma posição vertical no rebordo alveolar, e os que tiveram menor relação foram os distoangulados.

$$
\text { REJEBIAN }^{54}, \quad \text { em 1979, mostrou, em }
$$

ortopantomografias, que a distorção em radiográfica pode chegar a $58 \%$ na região dos pré-molares quando comparadas as medidas mésio-distais na radiografia panorâmica com modelos de gesso.

TRONJE $^{68}$, em 1982, afirma que a projeção utilizada na radiografia panorâmica, com feixes colimados (estreitos), pode resultar em distorção da imagem decorrente da angulação entre objetos ou dentes, de tamanho e detalhe, e ainda da morfologia do objeto ou dente.

SAMAWI; BURKE ${ }^{57}$, em 1984, mostraram uma variação na angulação dos dentes em radiografias panorâmicas de cerca de $5^{\circ}$, 
mas afirmaram que esta distorção pode ser desprezada, conforme o procedimento a ser realizado.

$\mathrm{SCHIFF}^{60}$, em 1986, discutiu os principais fatores que resultavam em erros na formação de imagem das radiografias panorâmicas e considerou o posicionamento incorreto do paciente como a principal causa destes erros.

CHANDLER; LASKIN ${ }^{15}$, em 1988, avaliaram a precisão da radiografia panorâmica na classificação dos terceiros molares inferiores. Em uma amostra com 20 terceiros molares, houve apenas 50\% de acerto na classificação e no tipo de cirurgia a ser empregada no tratamento destes dentes, mostrando que a classificação dos terceiros molares não irrompidos é importantíssima no planejamento cirúrgico dos mesmos. Os autores concluem afirmando que a radiografia panorâmica não é um meio confiável para o planejamento das exodontias de terceiros molares não irrompidos.

WELANDER; TRONJE; McDAVID ${ }^{74}$, em 1989, descreveram os princípios gerais da distorção radiográfica, vertical, horizontal e angular. A distorção angular é descrita como uma associação da distorção horizontal e vertical e os autores citam que um erro de $\pm 5^{\circ}$ pode ser tolerado, dependendo do tipo de procedimento clínico a ser realizado, e que a inclinação 
vestíbulo-lingual dos dentes pode aumentar a distorção angular. Os pesquisadores constataram que as medidas angulares realizadas com os dentes que sofriam este tipo de inclinação eram seriamente afetadas. Concluem que essas medidas angulares nas radiografias panorâmicas são bidimensionais, e que para a correta aferição da angulação de dentes não irrompidos, por exemplo, é necessária uma segunda exposição radiográfica, como uma radiografia oclusal.

Para estes autores a distorção na radiografia panorâmica está baseada no fato de que as dimensões verticais da imagem dependem do foco de projeção da fonte de raios $\mathrm{X}$, enquanto que as dimensões horizontais dependem da projeção dos centros de rotação do feixe central. Assim, as dimensões horizontais são afetadas pela velocidade do filme em relação aos raios X e o grau de distorção vertical depende da profundidade do objeto e de sua distância ao filme, ou seja, objetos posicionados longe do filme radiográfico aparecerão maiores e mais borrados, ao passo que objetos mais próximos aparecerão com pouca alteração de seu tamanho e mais nítidos (Figura 2.3). 


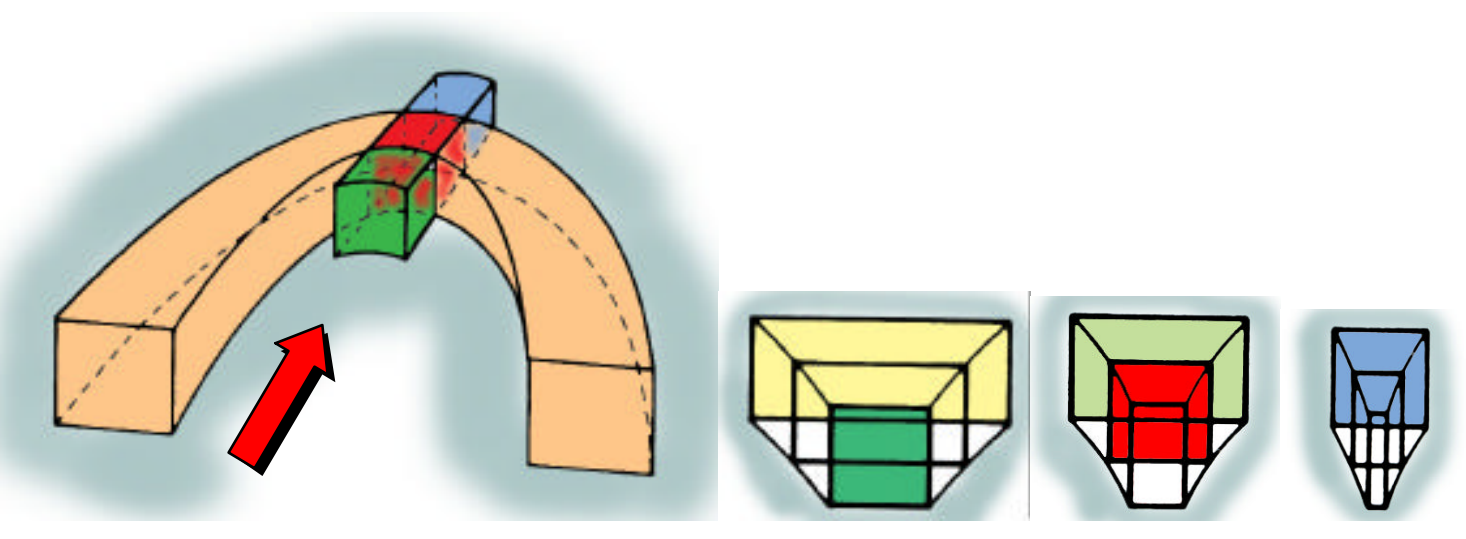

O objeto está mais longe do filme, logo terá uma maior distorção de sua imagem.

$\square$ O objeto está posicionado no plano de corte do aparelho panorâmico, causando pouca distorção de sua imagem.

$\square$ O objeto mais próximo do filme aparecerá menor em relação às outras estruturas radiografadas, com pouca distorção de sua imagem.

Figura 2.3 -Posicionamento dos objetos em relação ao filme radiográfico. A seta vermelha indica a incidência dos raios $\mathrm{X}$.

VENTÄ ${ }^{71}$, em 1991, baseou-se em achados radiográficos, utilizando-os como recurso auxiliar no diagnóstico de irrupção ou não do terceiro molar inferior após os 20 anos de idade. Dentre os dentes que irromperam até os 26 anos, constatou-se que, aos 20 anos, estes possuíam a raiz completamente formada, eram submucosos, classificados como verticais, estavam ao mesmo nível do plano oclusal do segundo molar adjacente, apresentavam espaço suficiente na distal do segundo molar até o ramo da mandíbula. Entre os fatores que indicam o não irrompimento estão a classificação de mesioangulado e a profundidade do dente no interior do osso. Os pesquisadores concluíram que as radiografias panorâmicas de indivíduos 
com mais de 20 anos podem fornecer subsídios para a previsibilidade do irrompimento dos terceiros molares.

SERMAN; BUCH ${ }^{61}$, em 1992, notaram que a distorção no tamanho das imagens da radiografia panorâmica pode auxiliar o clínico na determinação da posição do dente não irrompido e apresentaram como conclusão que o dente mais distante do filme aparecerá maior e mais distorcido (lingual ou palatino) enquanto que o dente mais próximo do filme (vestibular) aparecerá menor e mais nítido (Figura 2.3).

HAYAKAWA $^{30}$, em 1993, estudou a distorção em imagens produzidas por objetos esféricos em radiografias panorâmicas. Foi encontrada uma complexa relação entre a posição do objeto e o aumento do tamanho horizontal em cada região anatômica, sendo que as maiores alterações ocorreram na região de pré-molares e na linha média. A análise dos dados indica que a distorção de objetos esféricos é influenciada também pelo seu tamanho. Espera-se então, segundo os autores, uma distorção não só no contorno das estruturas, mas também nas estruturas internas do objeto.

\section{ALMEIDA; BOSCOLO; MONTEBELO FILHO ${ }^{4}$, em} 1995, mediram a distorção em radiografias de 2 aparelhos panorâmicos e observaram que as imagens obtidas tiveram um nível de distorção significante. A imagem obtida pelo elipsopantomógrafo apresentou menor distorção e maior 
homogeneidade quando comparada àquela obtida com o ortopantomógrafo. Houve maior distorção vertical na região dos pré-molares e maior distorção horizontal nos segmentos posteriores.

ÁVILA ${ }^{8}$, em 1996, afirma que é de fundamental importância o conhecimento da magnitude das distorções ao se examinar uma radiografia panorâmica. Conhecendo-se o índice de distorção esperado para o aparelho utilizado, pode-se avaliar melhor a morfologia do objeto estudado e sua relação com as estruturas adjacentes, propiciando uma interpretação mais segura da radiografia panorâmica. Quanto às características básicas da radiografia panorâmica, a autora explica que a formação da uma imagem radiográfica é produzida a partir de duas projeções centrais que agem simultaneamente. Uma delas é o centro de rotação, considerado o foco imaginário que determina a extensão horizontal da imagem. Este fator é afetado pela velocidade do filme em relação à velocidade do feixe. A outra é o feixe proveniente da área focal dos tubos de raios $\mathrm{X}$, considerado foco efetivo, proporcionando a extensão vertical da imagem. A imagem da radiografia panorâmica, denominada real, forma-se quando um objeto está localizado entre o centro de rotação e o filme. Imagens duplas são formadas quando o objeto está posicionado entre o centro de rotação e o filme sendo interceptado duas vezes pelo feixe de raios $\mathrm{X}$ (a coluna vertebral, por exemplo). 
Quando descreve o grau da distorção na formação da imagem na radiografia panorâmica, a autora mostra que essa distorção depende das características próprias de cada aparelho como forma e espessura da camada de corte e angulação dos raios $\mathrm{X}$. Além das distorções inerentes à técnica, fatores externos podem afetar o resultado final da radiografia, tais como: assimetria dos arcos dentários, posicionamento incorreto do paciente no aparelho e falta de cooperação do mesmo durante a execução da técnica.

A autora concluiu que a região paramedial, que compreende desde o canino até o terceiro molar, apresentou os maiores índices de distorção (até 63,5\%). 


\section{2 - CIRURGIA DOS TERCEIROS MOLARES INFERIORES}

\section{$\underline{2.2 .1-\text { Indicações }}$}

HAAVIKKO; ALTONEN; MATTILA ${ }^{27}$, em 1978, mostraram que a angulação dos terceiros molares de um grupo de pacientes avaliado dos 13 aos 19 anos, com valores iniciais de $23,3^{\circ}$ e finais de $13,9^{\circ}$, irromperam, e o grupo que necessitou de exodontia destes dentes possuíam uma angulação entre $23,6^{\circ}$ e $15,1^{\circ}$ respectivamente. A associação entre a angulação dos terceiros molares e o espaço no arco pode ser um indicativo do irrompimento ou não destes dentes, segundo os autores.

Em 1980, foi realizado um congresso da $\mathrm{NIH}^{44}$ (NATIONAl Institute OF HeALth), onde foram postulados alguns critérios para a remoção dos terceiros molares não irrompidos, tais como: a presença de infecção, lesão cariosa não restaurável, cistos, tumores, destruição de dente adjacente e tecido ósseo, e menor morbidade trans e pós-operatórias quando esses dentes são extraídos em pacientes jovens.

BRUCE; FREDERICKSON; SMALL ${ }^{12}$, em 1980, dividiram 900 pacientes em 3 grupos conforme a idade, e os avaliaram quanto a complicações pós-operatórias após a remoção dos terceiros molares inferiores. Detectou-se um aumento no número de problemas durante as cirurgias 
realizadas em pacientes acima dos 35 anos. Houve diferença estatisticamente significante no tempo cirúrgico para a exodontia no grupo de pacientes mais jovens (próximo aos 20 anos), em comparação ao grupo de pacientes mais velhos (acima de 35 anos), nos quais observaram também maior incidência de alveolite. Os autores recomendam que a exodontia dos terceiros molares inferiores seja realizada, de preferência, em pacientes mais jovens, pois o transcirúrgico e o pós-operatório são mais confortáveis ao paciente.

OSBORN et $\mathrm{a}^{46}$, em 1985, após um estudo envolvendo 9574 pacientes, totalizando 16127 exodontias, concluíram que quando realizadas em idades mais precoces (até os 24 anos), reduz-se significantemente a incidência de complicações pós-operatórias.

LEONE; EDENFIELD; COHEN ${ }^{36}$, em 1986, conseguiram relacionar a posição vertical ou discretamente distoangulada com a coroa parcialmente coberta pela mucosa alveolar, como as posições de maior risco para o desenvolvimento de pericoronarites.

STANLEY et $\mathrm{al}^{64}$, em 1988, após examinarem 11598 radiografias panorâmicas, totalizando 3702 terceiros molares não irrompidos, com impacção detectada de até 27 anos da constatação da presença destes dentes, os autores afirmaram que se pode esperar uma incidência de até $12 \%$ de 
patologias nestes dentes e concluem reforçando a idéia da remoção dos terceiros molares até a idade de 25 anos, mesmo que profilaticamente.

$$
\text { ELIASSON; HEIMDAHL; NORDENRAM }{ }^{22} \text {, em 1989, }
$$

avaliaram as indicações para a exodontia dos terceiros molares não irrompidos. Após a avaliação radiográfica de 644 pacientes que possuíam pelo menos um terceiro molar não irrompido, num total de 1211 dentes, foram observadas 84 lesões, sendo 25 na maxila e 59 na mandíbula. A lesão mais encontrada foi o cisto dentígero observado em 48 casos (5 na maxila e 43 na mandíbula). Concluem, então, que a remoção profilática dos terceiros molares deve ser feita com algumas ressalvas, sempre considerando o benefício da cirurgia e o possível custo de complicações trans-operatórias.

GIRDLER $^{25}$, em 1990, relata a reabsorção radicular total do segundo molar inferior esquerdo, em função da não remoção do terceiro molar. Na primeira radiografia panorâmica, foi constatada a presença do terceiro molar inferior esquerdo não irrompido, mas não havia lesão no segundo molar inferior adjacente ao dente. Depois de 3 anos da primeira radiografia panorâmica, foi realizado o primeiro controle radiográfico deste paciente, pois o mesmo não retornou às consultas previamente marcadas para controle do terceiro molar, e então verificou-se a reabsorção radicular do segundo molar inferior esquerdo pelo terceiro molar. O autor indica a remoção 
profilática dos terceiros molares, ou um controle radiográfico anual destes dentes.

AL-KHATEEB; EL-MARSAFI; BUTLER ${ }^{2}$, em 1991, relacionaram as indicações para a remoção de 642 terceiros molares de 412 pacientes, separando-as em indicações terapêuticas e profiláticas. Nesta amostra, 182 dentes foram removidos por razões profiláticas e 460 por razões terapêuticas. Houve 13 casos de alveolite $(7,1 \%)$ nos casos onde a remoção do terceiro molar foi indicada profilaticamente, e 101 casos de alveolite $(21,9 \%)$ no grupo onde a indicação cirúrgica foi terapêutica. Os autores concluíram que, nos casos onde há história de pericoronarite, terceiro molar cariado, periodontite, e uso de contraceptivos orais o risco de desenvolvimento de alveolite pós-operatória é maior. Neste trabalho, a incidência de alveolite foi de 114 casos $(17,8 \%)$.

PETERSON $^{48}$, em 1992, afirma que a saúde periodontal do segundo molar é melhor quando o terceiro molar está totalmente intra-ósseo e quando o paciente é jovem. Ressalta a importância de se removerem os terceiros molares parcialmente irrompidos para prevenir a formação de bolsas periodontais profundas e comprometimento do segundo molar por cárie. Em pacientes com mais de 35 anos de idade, os dentes não irrompidos devem ser mantidos intactos, a não ser que uma condição patológica seja instalada. 


\section{KAHL; GERLACH; HILGERS ${ }^{33}$, em 1994,}

acompanharam 251 pacientes tratados ortodonticamente, e encontraram 113 terceiros molares inferiores assintomáticos em 58 pacientes. Foi comparada a posição dos terceiros molares inferiores através de radiografia panorâmica, durante um período de 9 até 26 anos. Em 52 casos, o controle radiográfico mostrou mudança de posição dos terceiros molares inferiores, tendendo a uma posição mais verticalizada. Os autores recomendaram que pacientes, após a conclusão de um tratamento ortodôntico, se submetam a um controle radiográfico periódico a fim de se monitorarem mudanças nas condições e posição dos terceiros molares.

MARZOLA $^{40}$, em 1995, indica a remoção de um terceiro molar não irrompido quando este dente causar impacção de outro dente permanente; quando estiver em contato com o dente adjacente, podendo resultar em sua reabsorção; por razões ortodônticas; quando estiver semiirrompido, podendo causar infecções; quando houver presença de patologias ou em pacientes que serão submetidos à radioterapia na região maxilofacial.

PETERSON; ELLIS; TUCKER ${ }^{50}$, em 2000, propõem as seguintes indicações para a remoção dos terceiros molares inferiores: prevenção da saúde periodontal, prevenção da cárie dentária, prevenção da pericoronarite, prevenção da reabsorção radicular, prevenção de cistos e 
tumores odontogênicos e prevenção da fratura de mandíbula. Citam que, como o preceito fundamental da odontologia é a prevenção, é imposto a nós, cirurgiões-dentistas, que os dentes não irrompidos sejam removidos antes que surjam complicações. 


\subsection{2 - Incidência e prevalência}

DACHI e HOWELL ${ }^{18}$,em 1961, em um trabalho realizado com radiografias panorâmicas de crianças, adultos e idosos, encontraram uma incidência de $16,7 \%$ de dentes não irrompidos na população em geral, sendo os terceiros molares superiores de maior prevalência, seguido dos inferiores. Também estabelecerem que na população, em geral, de cada cinco terceiros molares, um não está irrompido.

O trabalho realizado por MORRIS e JERMAN ${ }^{43}$, em 1971, com radiografias panorâmicas de 5000 recrutas da Força Aérea Americana, com idade média de 19,5 anos, mostra um resultado diferente dos obtidos por DACHI e HOWELL ${ }^{18}$ em 1961. Neste trabalho, MORRIS e JERMAN $^{43}$ encontraram uma incidência de pelo menos um terceiro molar não irrompido em $65,5 \%$ das radiografias panorâmicas, e 22,3\% de voluntários com os quatro terceiros molares não irrompidos. O estudo obteve ainda uma incidência de 4,36\% de cistos relacionados com os terceiros molares não irrompidos.

AITASALO; LEHTINEN; OKSALA ${ }^{1}$ avaliaram 4063 radiografias panorâmicas de arquivo e obtiveram uma prevalência de 14,1\% de dentes não irrompidos, em que $76,1 \%$ deles eram terceiros molares, sendo pouco significante a diferença entre a mandíbula e maxila na incidência destes 
dentes. Os autores concluíram que a prevalência dos terceiros molares diminui conforme aumentada a idade dos pacientes, pois os dentes poderiam ter sido extraídos antes da realização da radiografia panorâmica.

ALATTAR; BAUGHMAN; COLLETT ${ }^{3}$, em 1980, examinaram 6780 radiografias panorâmicas para avaliar a incidência de achados patológicos. A patologia mais comum foi dente não irrompido, seguido da presença de raízes residuais.

DEBONI; GREGORI ${ }^{19}$, em 1990, realizaram um estudo para avaliar a prevalência da posição dos terceiros molares inferiores não irrompidos, chegando a resultados semelhantes aos de outros trabalhos. A maior prevalência foi a de dentes mesioangulados (46,9\%), seguida pelos verticais $(23,4 \%)$, horizontais $(21 \%)$, distoangulados $(6,7)$, transalveolares $(1,9 \%)$ e nenhum dente foi classificado como invertido.

OLIVEIRA $^{45}$, em 1996, após a interpretação radiográfica de 364 radiografias panorâmicas, encontrou 1019 terceiros molares e classificou-os da seguinte maneira (Tabela 2.1): 
Tabela 2. 1 - Incidência das posições dos terceiros molares inferiores obtidos por OLIVEIRA ${ }^{45}$, seguindo a classificação proposta por $\mathrm{WINTER}^{76}$.

\begin{tabular}{c|c|c}
\hline LADO ESQUERDO & LADO DIREITO & CLASSIFICAÇÃO \\
\hline $82 \%$ & $84 \%$ & MESIOANGULADOS \\
\hline $11 \%$ & $12 \%$ & VERTICAL \\
\hline $2 \%$ & -------- & DISTOANGULADOS \\
\hline $5 \%$ & $4 \%$ & HORIZONTAIS \\
\hline
\end{tabular}

SANTAMARIA; ARTEAGOITIA ${ }^{59}$, em 1997, estudaram 14 variáveis dos terceiros molares em radiografias panorâmicas, estabelecendo sua relação com o tempo cirúrgico. Sete variáveis demonstraram uma relação estatisticamente significante com o tempo cirúrgico (plano oclusal, relação com o segundo molar, profundidade, folículo pericoronário, espessura do ligamento periodontal, ramo da mandíbula, angulação). Concluíram também que a associação de duas variáveis, espessura de ligamento periodontal e profundidade, mostraram ser as mais sugestivas no que se refere ao aumento do tempo cirúrgico.

$\mathrm{AMIR}^{6}$, em 1998, estudou a variação angular em medidas feitas em radiografias panorâmicas, quando comparadas a mandíbulas secas. $\mathrm{O}$ autor constatou diferenças estatisticamente significantes com aumento dos valores angulares na radiografia. 
PINZAN; SANT'ANA; FERREIRA JR. ${ }^{52}$, em 1999, avaliaram através de radiografias panorâmicas de arquivo as posições dos terceiros molares inferiores dos pacientes atendidos nas clínicas de Cirurgia da Faculdade de Odontologia de Bauru, no período de 1992 a 1997. Foi constatado que a maior prevalência foi a da posição Vertical $(45,75 \%)$, seguida pela Mesioangular (36,25\%), Distoangular $(8,125 \%)$, Horizontal $(6,875 \%)$, Invertido $(2,25 \%)$ e Transalveolar $(0,75 \%)$. Quando os pacientes foram divididos pela idade, verificou-se que a posição mesioangular é mais freqüente em pacientes jovens, diminuindo à medida que a idade dos pacientes aumenta; que após os 20 anos, a incidência de dentes distoangulados aumenta; e que a frequiência das demais posições dos terceiros molares inferiores não se altera significantemente com a idade. 


\subsection{3 - Planejamento, posicionamento do terceiro molar e técnica}

\section{cirúrgica}

RICHARDSON $^{55}$, em 1978, ressalta importantes alterações da inclinação dos terceiros molares inferiores entre as idades de $16 \mathrm{e}$ 18 anos e constatou que a correta movimentação do terceiro molar não resulta necessariamente em seu irrompimento, pois o contato com o segundo molar pode impedi-lo, podendo causar uma impacção mesioangulada. O crescimento prematuro de uma das raízes pode causar ambém uma impacção vertical ou distoangulada, caso a raiz mesial seja a que sofreu esse crescimento. As impacções mesioanguladas e horizontais freqüentemente possuem uma raiz distal mais longa curvada para mesial.

SHILLER $^{62}$, em 1979, avaliou a mudança na posição dos terceiros molares inferiores no período de um ano, em 256 radiografias, totalizando 350 terceiros molares. Ao final de um ano de observação, 296 destes dentes tinham ocupado posições mais verticalizadas. $\mathrm{O}$ autor ressalta a importância de radiografias panorâmicas recentes para o planejamento cirúrgico dos terceiros molares inferiores.

Van GOOL, em 1975, apud, WESTESSON; CARLSSON $^{75}$, achou discrepantes os achados radiográficos de 932 terceiros molares inferiores, quando comparados com achados clínicos após as 
exodontias. Quando estes achados foram comparados com radiografias intrabucais, o número de dilacerações radiculares encontradas foi maior que o dobro das encontradas com radiografias panorâmicas.

\section{WESTERSON; CARLSSON ${ }^{75}$, em 1980, preconizam o} uso de três exposições radiográficas (periapical convencional, periapical com ângulo vertical de $-10^{\circ}$ e oclusal) para a correta avaliação da posição e relações com o canal mandibular. Este método funciona como uma localização pela técnica de Clark para as duas primeiras exposições. Afirmaram que a possibilidade de uma informação mais precisa compensa a maior exposição do paciente às radiações ionizantes.

BROCKBANK $^{10}$, em 1981, mostra um controle radiográfico de 2 anos onde houve uma horizontalização dos terceiros molares inferiores. No lado direito do paciente havia a presença de um cisto dentígero, o que podia explicar a alteração da posição deste dente, que era mesioangulado e tornou-se horizontal. Mas não houve explicação para o terceiro molar inferior esquerdo ter se horizontalizado, já que era também mesioangulado e não havia qualquer sinal de patologia associada ao dente. $\mathrm{O}$ autor conclui, ressaltando a necessidade de se acompanhar o irrompimento dos dentes e do uso de uma radiografia panorâmica recente para o planejamento cirúrgico dos dentes não irrompidos. 
GURALNICK $^{26}$, em 1984, considera que a antibioticoterapia racional, critérios cirúrgicos e a habilidade do profissional são fatores indispensáveis no tratamento cirúrgico dos terceiros molares. De acordo com o autor, a radiografia panorâmica não é um recurso complementar de diagnóstico perfeito, pois lesões com aspectos radiográficos semelhantes podem apresentar comportamentos biológicos muito diferentes. Citou, como exemplo, o queratocisto odontogênico que pode ser confundido com o cisto dentígero. Concluiu afirmando que a radiografia panorâmica somente delineia o problema e que apenas os exames complementares mais precisos podem realmente levar ao diagnóstico final. Recomendou que uma radiografia panorâmica deve ser feita em todos os pacientes, pelo menos uma vez ao ano, com a finalidade de se detectar lesões precocemente, o que resultaria em um tratamento mais conservador.

TAIT $^{66}$, em 1984, comparou a angulação dos terceiros molares inferiores dos dois la dos da mandíbula em 50 radiografias panorâmicas de crianças que tiveram migração mesial dos dentes posteriores permanentes devido à extração unilateral dos segundos molares decíduos. Em 36 casos, o terceiro molar do lado em que foi realizada a extração estava menos inclinado. $\mathrm{O}$ autor concluiu que existe indício de que a migração precoce dos dentes posteriores permanentes reduz a inclinação dos terceiros molares inferiores. 
SWERIN $^{65}$, em 1987, ressaltou a importância da localização da verdadeira posição de dentes não irrompidos, na correta avaliação do risco de infecção no espaço pericoronário, dentre outras complicações trans-operatórias. Conclui que a correta e cuidadosa interpretação das radiografias ajudará o cirurgião a prever possíveis dificuldades durante a cirurgia.

GARCIA; CHAUNCEY ${ }^{24}$, em 1989, fizeram um acompanhamento de 10 anos em 97 pacientes adultos que apresentavam terceiros molares não irrompidos, e verificaram que neste período, 14 dentes foram extraídos, 11 dentes irromperam, sendo que 3 destes estavam em oclusão. A posição de 4 dos dentes que irromperam permaneceu a mesma quando comparadas, através de marcações radiográficas, mostrando que a reabsorção alveolar e redução do tecido gengival na distal do segundo molar pode ser uma das causas do irompimento dos terceiros molares em adultos. Mudanças significantes na posição foram observadas em 7 dos 11 dentes que irromperam, quando comparadas as radiografias recentes com as de 10 anos atrás. Os autores terminam o trabalho concluindo que a irrupção de terceiros molares em adultos é um fenômeno mais freqüente do que se imaginava.

VON WOWERN; NIELSEN ${ }^{73}$, em 1989, acompanharam durante 4 anos a evolução de 130 terceiros molares de uma amostra com 70 
pacientes, e constataram que terceiros molares não irrompidos em pacientes de 20 a 24 anos podem vir a irromper.

\section{STAGGERS; GERMANE; FORTSON ${ }^{63}$, em 1992,} afirmaram que os tratamentos ortodônticos envolvendo as extrações dos prémolares não melhoram a angulação dos terceiros molares, quando comparados aos achados em pacientes com tratamento ortodôntico sem extrações dos prémolares, pois os trabalhos de HAAVIKKO; ALTONEN; MATTILA ${ }^{27}$ mostram que quanto menor for a inclinação do terceiro molar dos 13 aos 19 anos, maior a probabilidade deste vir a irromper. Concluíram afirmando que uma melhora na angulação dos terceiros molares não indica se o dente irá ou não irromper em boa posição, sendo prudente avisar aos pacientes que, mesmo após a extração dos pré-molares, poderá haver necessidade de extração futura dos terceiros molares.

$$
\text { RICHARDSON }^{56} \text {, em 1992, avaliou a mudança na }
$$
posição dos terceiros molares inferiores de 41 pacientes com idade entre 18 aos 21 anos por 3 anos, em um total de 72 terceiros molares. A mudança na angulação dos terceiros molares variou de $39^{\circ}$ a $-46^{\circ}$ no sentido mésio-distal. Apenas 10 terceiros molares não mudaram sua posição durante os 3 anos e 4 irromperam completamente. $\mathrm{O}$ autor concluiu que entre os 18 e 21 anos muitos 
terceiros molares mudaram sua posição, apesar do estágio avançado de desenvolvimento radicular.

MARZOLA $^{41}$, em 1995, propõe uma análise criteriosa de alguns aspectos na radiografia panorâmica durante o planejamento de uma cirurgia de um terceiro molar inferior; dentre eles, o autor destaca a posição do terceiro molar inferior, a posição do segundo molar adjacente, a relação do terceiro molar com a borda anterior do ramo da mandíbula, a profundidade relativa do terceiro molar inferior retido no osso mandibular, a avaliação da integridade da coroa do terceiro molar e a avaliação das raízes e septo interradicular do terceiro molar. $\mathrm{O}$ autor ainda propõe e descreve em detalhes uma técnica cirúrgica a ser utilizada na exodontia do terceiro molar inferior.

$\operatorname{HATTAB}^{28}$, em 1997, verificou a mudança na angulação dos terceiros molares não irrompidos, através de radiografias panorâmicas de pacientes adultos-jovens, que foram proservados por 4 anos. Dos 59 terceiros molares mesioangulados, $59 \%$ estavam entre 5 e $20^{\circ}, 17 \%$ com mais de $35^{\circ}$, 44\% irromperam e $34 \%$ ficaram em posição vertical. Em 4 anos, $78 \%$ dos dentes mudaram de posição. Este estudo mostra um método para a aferição da inclinação dos terceiros molares inferiores adotado por esta pesquisa (Figura 2.4). 


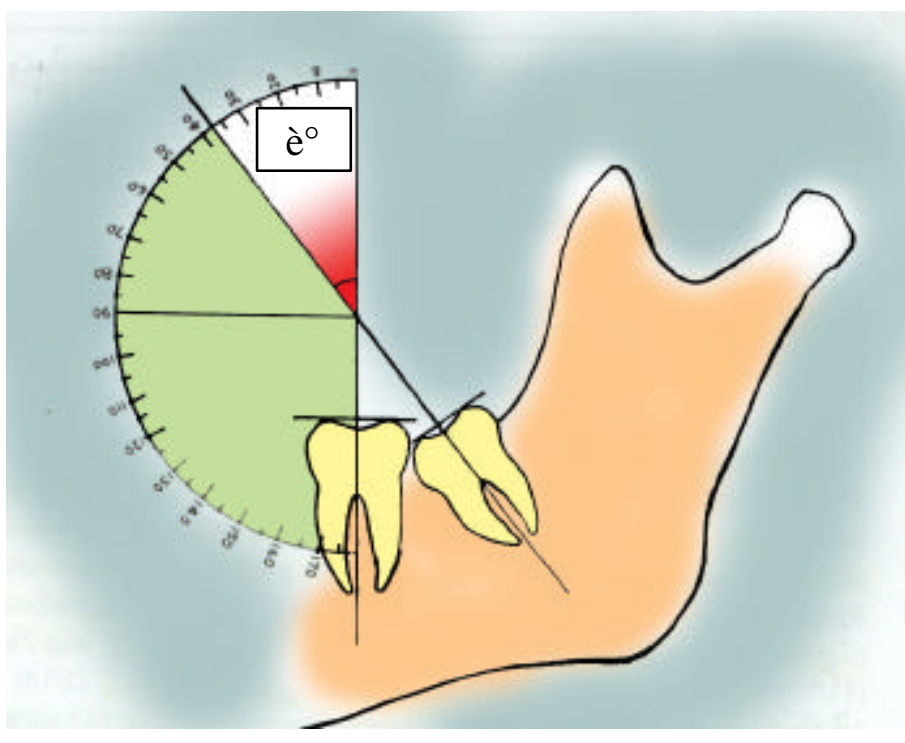

Figura 2.4 - Esquema da aferição do ângulo que determinará a classificação do terceiro molar, onde $\theta$ é o valor do ângulo formado entre os longos eixos do segundo e do terceiro molar.

IIZUKA $^{32}$, em 1997, em um estudo retrospectivo da incidência de fraturas mandibulares associadas a exodontia dos terceiros molares, constatou que a idade avançada, graus de impacções ósseas profundas e as posições mesioangulares e distoangulares dos terceiros molares aumentam as chances de ocorrência de fraturas mandibulares. $\mathrm{O}$ autor relata ainda que estas fraturas costumam ocorrer tardiamente, sendo raras durante a cirurgia.

VENTÄ; TURTOLA; YLIPAAVALNIEMI ${ }^{74}$, em 1999, publicaram o resultado do mais longo controle radiográfico de terceiros molares em adultos na literatura (12 anos). Os pacientes foram proservados dos 20 aos 32 anos de idade. Os autores constataram muitas mudanças nos terceiros 
molares, sendo a mudança de posição a mais freqüente, e que $22 \%$ dos dentes irromperam.

HATTAB; ALHAIJA ${ }^{29}$, em 1999, em um estudo com 134 radiografias panorâmicas, onde avaliaram 213 terceiros molares com relação ao espaço retromolar em dentes irrompidos e não irrompidos. A avaliação do espaço retromolar no grupo que os terceiros molares eram não irrompidos foi estatisticamente significante menor em relação ao grupo onde havia o terceiro molar irrompido. Mesmo quando o espaço retromolar era considerado adequado, $17 \%$ dos terceiros molares não irromperam.

$$
\text { PETERSON, ELLIS e TUCKER }{ }^{49} \text {, em 2000, }
$$
propuseram e descreveram uma seqüência cirúrgica a ser aplicada na remoção de um terceiro molar não irrompido. Os autores propuseram modelos de incisão, ostectomias e odontosecção, onde utilizaram canetas de baixa rotação com irrigação de soro fisiológico e brocas $\mathrm{n}^{\circ}$ 702, posicionamento dos extratores e sutura.

LEE; DODSON ${ }^{35}$, em 2000, avaliaram a presença de terceiros molares inferiores e o risco de ocorrência de fraturas no ângulo da mandíbula. Constataram que pacientes com um terceiro molar inferior têm uma probabilidade 2 vezes maior de ocorrência de fratura mandibular, em relação a pacientes que não possuíam terceiros molares. Houve ainda variação 
estatisticamente significante no risco de fratura de ângulo dependendo da posição do terceiro molar; as posições com maior frequiência de fraturas de ângulo da mandíbula foram os mesioangulados totalmente intra-ósseos. 


\section{3- SILICONAS DE ADIČÃO}

COOK; THOMASZ ${ }^{17}$, em 1986, avaliaram, através de um questionário entre os cirurgiões-dentistas, A necessidade do uso de luvas de látex na manipulação de siliconas de adição. Observaram um consenso, entre os entrevistados, de que a manipulação da silicona de adição, com a utilização de luvas de borracha interferia na polimerização da mesma. Acreditava-se que isso ocorria pela presença do talco nas luvas, mas, verificou-se que os componentes derivados de enxofre presentes em todas as luvas de borracha eram os responsáveis pelo retardo na polimerização das siliconas de adição. Os autores recomendam o uso de luvas de vinil, ou mãos limpas na manipulação das siliconas de adição, a fim de não se prejudicar a reação química.

$$
\text { PHILLIPS }^{51} \text {, em 1993, ARAÚJO }{ }^{7} \text { et al., em 1992, }
$$

conceituam os elastômeros pela especificação n. 19 da ADA (AMERICAN Dental Association), como materiais elastoméricos não-aquosos para moldagens odontológicas, sendo também chamados de borrachas sintéticas, com polimerização feita por reação de adição. Os autores fizeram uma relação das propriedades químicas e biológicas das siliconas de adição, evidenciando que os principais problemas biológicos das siliconas são os restos que possam ser deixados no local da moldagem. Ressaltaram que as siliconas podem ser 
desinfetadas por soluções antimicrobianas sem causar alterações dimensionais, desde que o período de desinfecção seja curto.

\section{DEN BRABER; RUITJER; JANSEN ${ }^{20}$, em 1997,} avaliaram o comportamento de implantes de silicone envoltos por uma borracha de silicone no tecido subcutâneo de coelhos. Não houve reação inflamatória dos implantes mostrando a biocompatibilidade da borracha de silicone.

$\mathrm{VALLE}^{70}$, sugere que o material de moldagem ideal deve possuir algumas propriedades, dentre elas, ser atóxico, possuir tempo de trabalho satisfatório, possuir estabilidade dimensional e ser passível de desinfecção sem alterar suas propriedades. 
3 - PROPOSIÇÃO 


\section{3 - PROPOSIÇÃO}

A partir da observação de radiografias panorâmicas de pacientes que necessitam da exodontia dos terceiros molares inferiores, este trabalho propõe-se a:

Avaliar a angulação do terceiro molar inferior, segundo WINTER $^{76}$, na radiografia panorâmica.

Avaliar a angulação do terceiro molar inferior, segundo WINTER ${ }^{76}$, nos modelos de gesso (obtidos durante moldagem trans-cirúrgica).

Avaliar se a distorção angular da radiografia panorâmica pode alterar esse posicionamento quando se compararem os valores obtidos na radiografia panorâmica e nos modelos de gesso. 
4 - MATERIAL E MÉTODOS 


\section{4 - MATERIAL E MÉTODOS}

\section{1 - MATERIAL}

\subsection{1 - Exame e seleção dos pacientes}

A amostra utilizada neste trabalho foi composta por 15 pacientes que procuraram a clínica de cirurgia da Faculdade de Odontologia de Bauru com indicação de exodontia dos terceiros molares, totalizando 19 cirurgias.

Os pacientes foram selecionados através de radiografias panorâmicas recentes, de acordo com os seguintes critérios:

Presença de pelo menos um terceiro molar inferior não irrompido ou parcialmente irrompido.

Dentes classificados como invertidos ou transalveolares, de acordo com a classificação de WINTER $^{76}$, eram excluídos. 
O dente deveria ser classificado como I A de acordo com PEEL \& GREGORY ${ }^{49}$.

Possuir maioridade legal.

O procedimento cirúrgico deveria ser realizado dentro de 30 dias da data da tomada radiográfica.

Os pacientes deveriam estar em condições físicas adequadas para se submeter à cirurgia sob anestesia local, após exame clínico (anamnese e exame físico).

Uma vez preenchidos estes requisitos, o paciente recebia uma cópia impressa da CARTA DE INFORMAÇÃO AO PACIENTE (Anexo 3) seguida por um TERMO DE CONSENTIMENTO LIVRE E ESCLARECIDO (Anexo 4), seguindo as normas da Resolução 196/96 do CONEP.

Após a leitura da carta de informação ao paciente e assinatura do termo de consentimento livre e esclarecido, agendava-se a cirurgia do paciente dentro do prazo estabelecido pelos critérios de seleção da amostra. 


\subsection{2 - Aparelhos de raios $X$, filmes e processamento radiográficos.}

As radiografias utilizadas neste estudo foram obtidas a partir de um único aparelho panorâmico, o Rotograph Plus® produzido pela Villa Sistemi Medicalli®, operando, em média, com 70 kvp e sempre com 10 mA. O filme radiográfico utilizado foi da marca Kodak, tipo T-MAT, que eram acondicionados adequadamente em chassi metálico, com ecran intensificador da marca Kodak - tipo lanex regular.

As tomadas radiográficas foram sempre feitas pelo mesmo operador.

Após a identificação, as radiografias foram processadas em processadora automática Cronex T4 Processor ${ }^{\circledR}$, produzido pela Dupont Equipment ${ }^{\circledR}$, operando com líquidos de processamento Kodak e tempo de processamento de 1 minuto e 50 segundos de seco a seco.

\subsection{3 - Ficha para registro de medidas clínicas e radiográficas}

Foi elaborada uma ficha para o registro das informações obtidas na radiografia panorâmica e dos modelos de gesso.

Nesta ficha constavam os seguintes dados: a identificação do paciente seguido pelo número do prontuário da Disciplina de 
Cirurgia da Faculdade de Odontologia de Bauru - Universidade de São Paulo, e o ângulo formado entre o longo eixo do terceiro molar e do segundo molar adjacente na radiografia panorâmica, e sua classificação, de acordo com WINTER $^{76}$, para os terceiros molares, seguindo os valores propostos por $\operatorname{HATTAB}^{28}$, onde:

\begin{tabular}{c|c}
\hline$\underline{\text { Valor angular }}$ & $\underline{\text { Classificação }}$ \\
\hline$-30^{\circ}$ a $-5^{\circ}$ & Distoangulado \\
\hline$-5^{\circ}$ a $5^{\circ}$ & Vertical \\
\hline $5^{\circ}$ a $55^{\circ}$ & Mesioangulado \\
\hline $55^{\circ}$ a $105^{\circ}$ & Horizontal \\
\hline
\end{tabular}

Tabela 4.1 - Valores angulares utilizados como parâmetros de classificação dos terceiros molares inferiores neste trabalho.

Nesta ficha também eram anotadas as variações das medidas encontradas. (Anexo 5)

\subsection{4-Material para cirurgia}

\subsubsection{1-}

Foi utilizado, para a anti-sepsia intrabucal, bochecho com Listerine ${ }^{\circledR}$ por 30 segundos, para a anti-sepsia da face do paciente usou-se gaze embebida por Sterylderm ${ }^{\circledR}$ presa por pinça do tipo Allis; e para a 
desinfecção da moldagem foi usada solução de Glutaraldeído $20 \%$ (Glutacide ${ }^{\circledR}$ ) por 30 minutos.

\subsubsection{2 - Campo cirúrgico}

As cirurgias foram realizadas, obedecendo às normas de biossegurança da FOB-USP vigentes no período, com "kit" de campos cirúrgicos descartáveis, oferecidos pela empresa Vaayus® (Indústria e Comércio de Descartáveis, com sede em São Carlos - SP, esterilizados por Óxido de Etileno pela Acecil® com sede em Campinas - SP), do qual constavam 1 campo para mesa de 50 x $50 \mathrm{~cm}$, um campo fenestrado para o paciente de 1,0 $\mathrm{m} \times 1,0 \mathrm{~m}$, protetor de refletor odontológico, protetor de sugador e protetor de caneta de alta rotação.

\subsubsection{3 - $\underline{\text { Anestesia }}$}

Para a anestesia dos pacientes, foram utilizados anestésicos locais com vaso constritor rotineiramente utilizados pelas disciplinas de Cirurgia da Faculdade de Odontologia de Bauru. Sua composição química é o cloridrato de Mepivacaína 2\% com noradrenalina, encontrado no comércio com o nome de Scandicaíne® 2\%. Para a injeção do 
anestésico, foram usadas agulhas curtas descartáveis, todas montadas em seringa do tipo Carpulle.

\subsubsection{4 - Instrumental cirúrgico}

Para a cirurgia, utilizou-se o seguinte instrumental, montado sobre uma mesa com campo cirúrgico esterilizado (Figura 4.1):

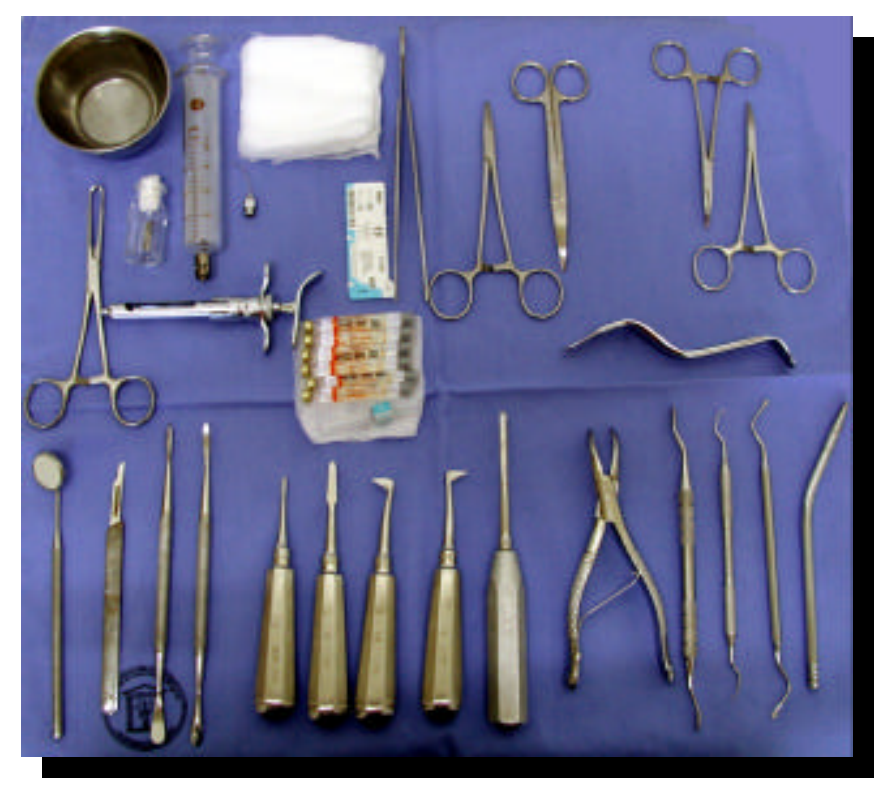

Figura 4.1 - Mesa com o instrumental cirúrgico colocado para a realização da exodontia do terceiro molar inferior.

\subsubsection{5 - Irrigação do alvéolo e sutura}

Foi utilizada, neste trabalho, solução de soro fisiológico a 0,9\%, para irrigação do retalho e do alvéolo. Para a sutura, usouse fio de seda $\mathrm{n}^{\circ} 4-0$ com $45 \mathrm{~cm}$ de comprimento, em agulha montada de hemi-

\footnotetext{
* De acordo com as normas da Comissão de Biossegurança da FOB-USP vigentes na época da realização da foto, os campos cirúrgicos descartáveis foram substituídos por campos de algodão lavados e esterilizados.
} 
secção triangular, com o nome comercial de ETHICON®, fabricada pela JONHSON \& JONHSON®.

\subsection{5-Material de moldagem}

A moldagem foi feita em duas etapas, como recomendado pelo fabricante. Utilizou-se a silicona de adição Splash®, produzida pela Vivadent® (Figura 4.2 A e B). A moldagem foi realizada manualmente, sem a utilização de moldeiras. Sobre a primeira moldagem (pesada), foi feita a moldagem leve, com material mais fluido, conseguindo riqueza de detalhes, sem distorções.

Dentre todos os tipos de materiais disponíveis para a moldagem, as siliconas de adição apresentam maior estabilidade dimensional, menor deformação após a presa do material, melhor tolerância quanto ao tempo necessário ao vazamento do gesso, além de possuir excelente reprodução de detalhes, bom tempo de trabalho, facilidade no uso, manipulação e remoção. As siliconas não possuem odor desagradável ao paciente e podem ser esterilizadas $^{7,52,73}$. 


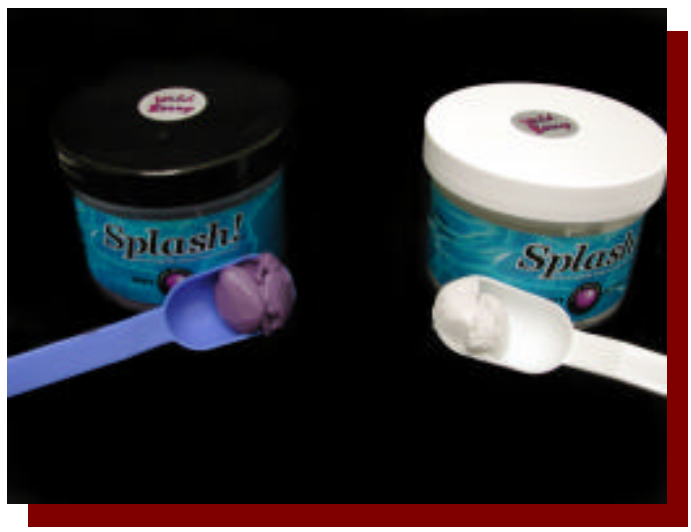

A

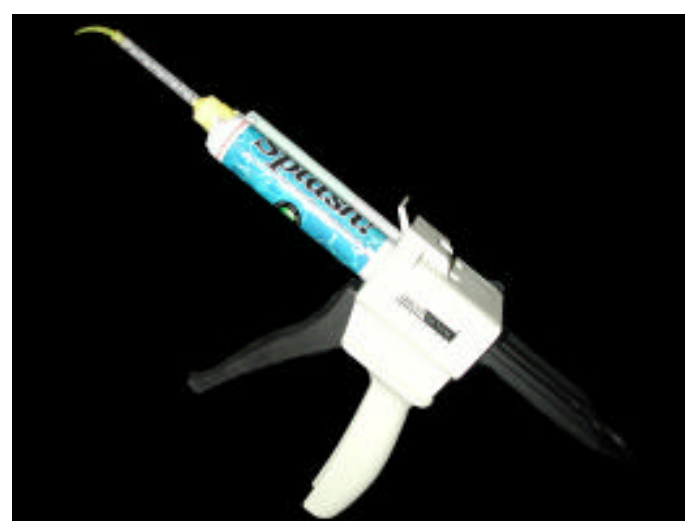

$\mathrm{B}$

Figura 4.2 A e B - Silicona de adição utilizada nesta pesquisa. (A)As duas pastas base (roxa e branca) que serão misturadas para a realização da moldagem pesada pré-cirúrgica. (B) Dispensador automático para a moldagem fluida que será realizada no trans-cirúrgico.

O material fluido utilizado na segunda moldagem é mantido esterilizado no interior do dispensador automático, que é desprezado após seu uso.

\subsection{6-Modelos de gesso}

Os modelos foram confeccionados em gesso pedra tipo IV (Durone®), pois este oferece menor distorção de tamanho do modelo

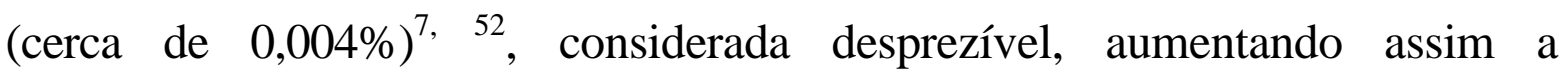
confiabilidade das medidas obtidas a partir dos modelos e por reproduzirem perfeitamente o local da moldagem (Figura 4.3). 


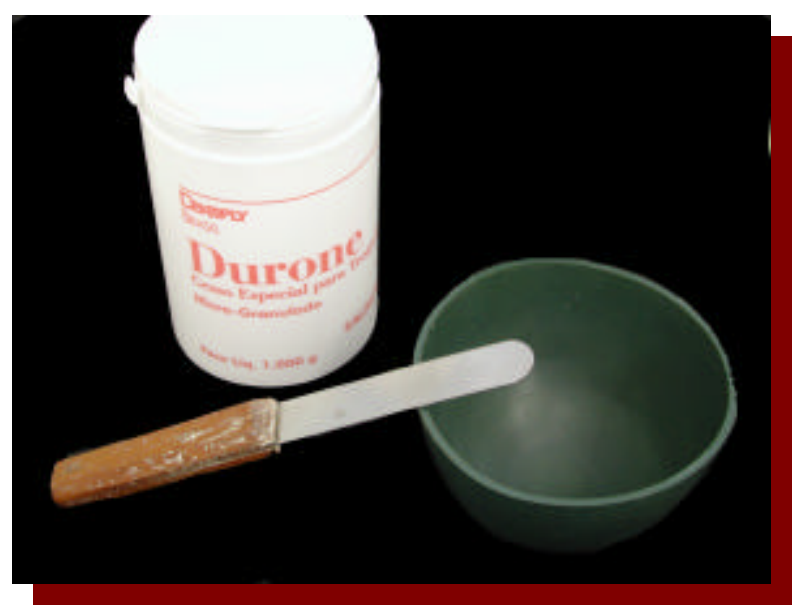

Figura 4.3 - Gesso tipo IV utilizado na confecção dos modelos de gesso.

\subsection{7-Obtenção das medidas}

Para uma interpretação radiográfica adequada, foi utilizado um negatoscópio em sala escura; e para o traçado, utilizaram-se papel vegetal, lápis preto $n .^{\circ} 2$, régua milimetrada e transferidor.

Para esta pesquisa, desenvolveu-se um dispositivo que realizaria a leitura correta do ângulo formado entre o segundo e o terceiro molar nos modelos de gesso (Figura 4.4) (Anexos 7.1, 7.2 e 7.3).

Este dispositivo foi confeccionado com acrílico para que proporcionasse resistência aos movimentos necessários para a obtenção das medidas angulares; e transparência para a visualização do correto posicionamento dos pontos a serem medidos, e constava de:

Uma base em "L", medindo 7,5cm X 7,5cm, com $6 \mathrm{~mm}$ de largura e $2 \mathrm{~mm}$ de espessura. 
Uma base vertical que "corre" sobre a base "L", estando sempre paralela à parte vertical da base " $L$ ".

Transferidor transparente com marcação de $180^{\circ}$.

Duas pontas metálicas na base "L", com ajuste de altura.

Uma ponta metálica que transfixa o transferidor e a base vertical, com ajuste de altura.

Marcação no acrílico na região superior da base vertical que coincida com o paralelismo das duas bases e com o ângulo reto do transferidor.

Jogo de chaves de fenda para manipulação do dispositivo

3 parafusos M2 x 14mm (devem-se confeccionar as pontas com o uso de tornos), porcas M2 cestavada e roelas M2.

O dispositivo foi projetado de forma que todos os componentes possam ser trocados de posição, permitindo seu uso nos lados esquerdo e direito, bastando apenas mudar o transferidor de lado. 


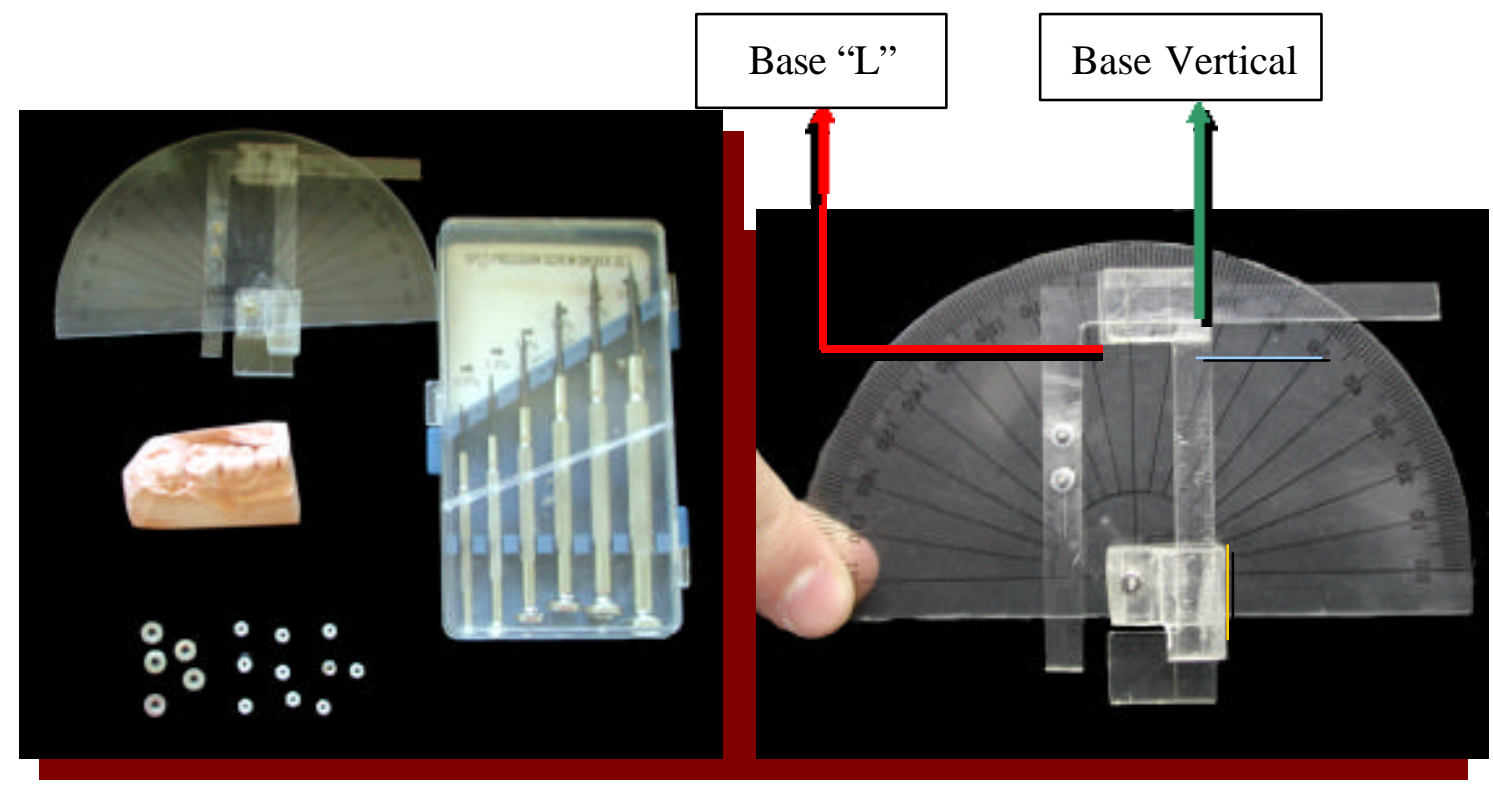

Figura 4.4 - Dispositivo utilizado para medição dos ângulos nos modelos de gesso.

$\square$ Movimentação que a base vertical faz sobre a base "L".

$\square$ Movimentação que o transferidor faz sobre a base vertical.

\section{2 - MÉTODOS}

\subsection{1-Radiografia panorâmica}

As radiografias panorâmicas foram realizadas no mesmo

aparelho panorâmico e o paciente era devidamente protegido com o uso de avental de borracha plumbífera. Presilhas, brincos e outros objetos metálicos que interferissem na obtenção da imagem radiográfica foram removidos e guardados pelo próprio paciente. 
Foram observados rigorosamente pelo operador os seguintes critérios para a obtenção de uma boa imagem radiográfica ${ }^{5,23,34}$ :

Plano sagital mediano perpendicular ao solo.

Plano de Frankfurt paralelo ao solo.

Regime de trabalho,de acordo com cada paciente.

Processamento automático após identificação do

filme.

4.2.2 - Critérios para a seleção dos pacientes e classificação dos $\underline{\text { terceiros molares }}$

Feita a interpretação radiográfica pelo pesquisador, e eliminados da amostra deste estudo os pacientes onde os terceiros molares apresentavam as posições trans-alveolares e invertidas, os pacientes selecionados eram agendados para que fossem realizados o exame clínico e, posteriormente, a cirurgia, sempre respeitando um período máximo de 30 dias após a realização da radiografia panorâmica (Figura 4.5). 


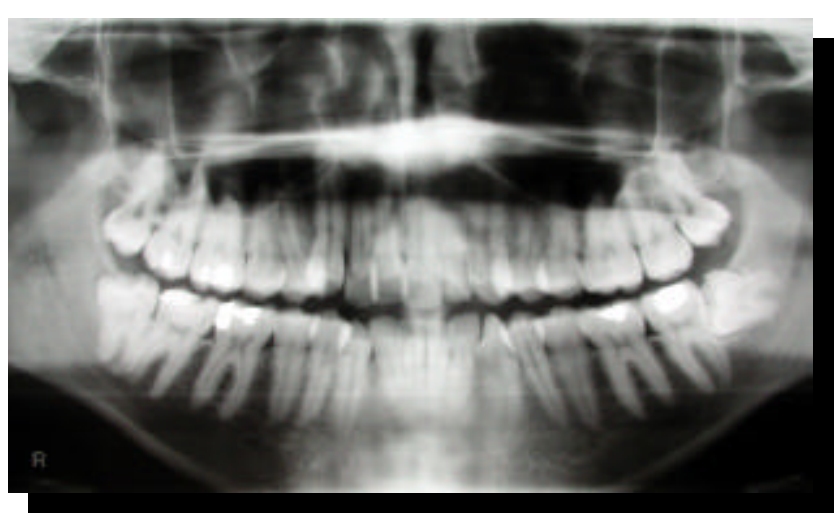

A

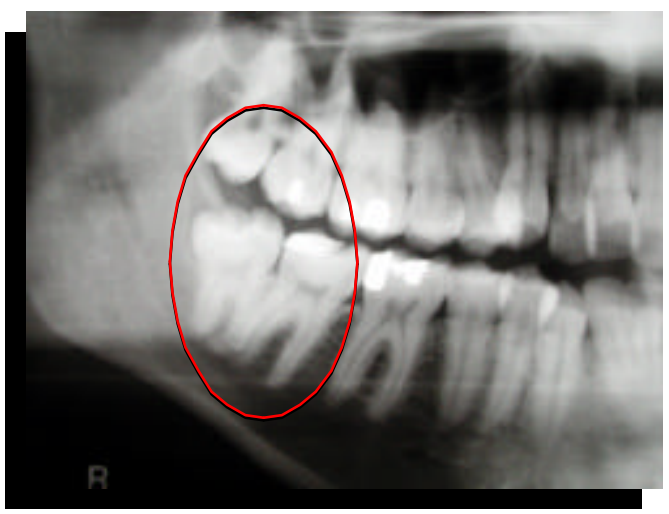

B

Figura 4.5 A e B -(A) Radiografia panorâmica. (B) Destaque do terceiro molar que será extraído.

Nesta etapa ainda não era necessária uma observação apurada com relação aos valores de angulação entre o terceiro molar inferior e o segundo molar adjacente, pois neste momento visávamos somente à seleção do paciente e avaliação da necessidade da exodontia dos dentes em questão.

Caso houvesse alguma dúvida na classificação do dente (principalmente para invertido), era realizado um traçado da radiografia panorâmica em papel vegetal e feita a medida do ângulo formado entre o segundo e terceiro molar. Caso confirmada a posição invertida, o paciente era excluído da amostra, mas continuava sendo atendido nas clínicas de cirurgia da FOB-USP.

Segundo os critérios estabelecidos por $\mathrm{HATTAB}^{28}$, e descritos anteriormente neste mesmo capítulo, não foram incluídos pacientes 
onde o ângulo formado entre o terceiro e o segundo molar fossem maiores do que $105^{\circ}$ e menores do que $-30^{\circ}$.

Com relação aos dentes em posições trans-alveolares, a interpretação radiográfica era suficiente para estabelecer sua classificação.

Os pacientes que possuíam um dos terceiros molares nestas posições, e um outro que poderia ser usado para a pesquisa, estes eram selecionados e tratados, porém os dentes invertidos e trans-alveolares não eram incluídos na amostra, mas atendidos pelo próprio pesquisador.

\subsection{3-Exame clínico}

Depois da seleção do paciente através da radiografia panorâmica, agendava-se uma consulta para exame clínico (anamnese e exame físico), com a realização ou não da cirurgia no mesmo dia, de acordo com a disponibilidade de horário e principalmente das condições físicas e psicológicas do paciente.

Nesta consulta, era estabelecida a relação pacienteprofissional, examinando-se e esclarecendo o paciente quanto aos objetivos da pesquisa e ao tratamento cirúrgico. 
Após a leitura da CARTA DE INFORMAÇÃO DO PACIENTE (Anexo 3), onde os objetivos e os procedimentos estavam descritos, o paciente recebia uma cópia da carta e assinava O TERMO DE CONSENTIMENTO LIVRE E ESCLARECIDO (Anexo 4), que recebia também a assinatura do pesquisador, seguindo os protocolos do Comitê de Ética em Pesquisa da Faculdade de Odontologia de Bauru - Universidade de São Paulo.

\subsubsection{1- $\underline{\text { Anamnese }}$}

A anamnese utilizada neste estudo foi baseada em perguntas objetivas, cuja finalidade era a obtenção da história médica do paciente.

Esse questionário faz parte da ficha que é rotineiramente preenchida nas Disciplinas de Cirurgia e Estomatologia da Faculdade de Odontologia de Bauru - Universidade de São Paulo (Anexo 2.1)

Se o paciente não apresentasse condição clínica adequada no período previsto na metodologia, era excluído desta amostra e seu tratamento era realizado posteriormente. Em nossa amostra, houve apenas um caso onde esta conduta foi necessária. 


\subsubsection{2 - Exame fisico}

Seguindo-se a metodologia de exame do paciente, proposta pela disciplina de Estomatologia da Faculdade de Odontologia de Bauru - Universidade de São Paulo, foi realizado o exame físico local e locoregional onde poderíamos constatar patologias nos tecidos bucais e na região maxilofacial. (Anexo 2.2).

Caso alguma alteração fosse encontrada, avaliava-se a necessidade de se realizar a exodontia, considerando a relação entre a patologia encontrada e a cirurgia, como acontece com as pericoronarites. Nestes casos, o paciente era encaminhado para tratamento médico ou odontológico e só depois era agendada a exodontia do terceiro molar inferior, desde que o tempo proposto pela metodologia deste estudo fosse respeitado.

Durante o exame físico, eram avaliados os sinais vitais dos pacientes (pressão arterial, pulso, respiração e temperatura); nos casos em que alguma alteração fosse constatada, o paciente era encaminhado ao serviço médico especializado. 


\subsection{4-Primeira moldagem}

No dia em que a cirurgia ocorreu, realizaram-se os procedimentos de moldagem com silicona de adição. Essa moldagem foi feita em duas etapas, uma antes e outra durante a cirurgia.

Para a primeira moldagem (moldagem pesada), utilizamos uma mistura de duas pastas (base e catalisadora) em pequena quantidade, sem o uso de luvas de borracha, como preconizado, pois o látex das luvas interfere nas propriedades químicas das siliconas, alterando sua estabilidade dimensional $^{7,17,52}$ (Figura 4.6 A, B e C).
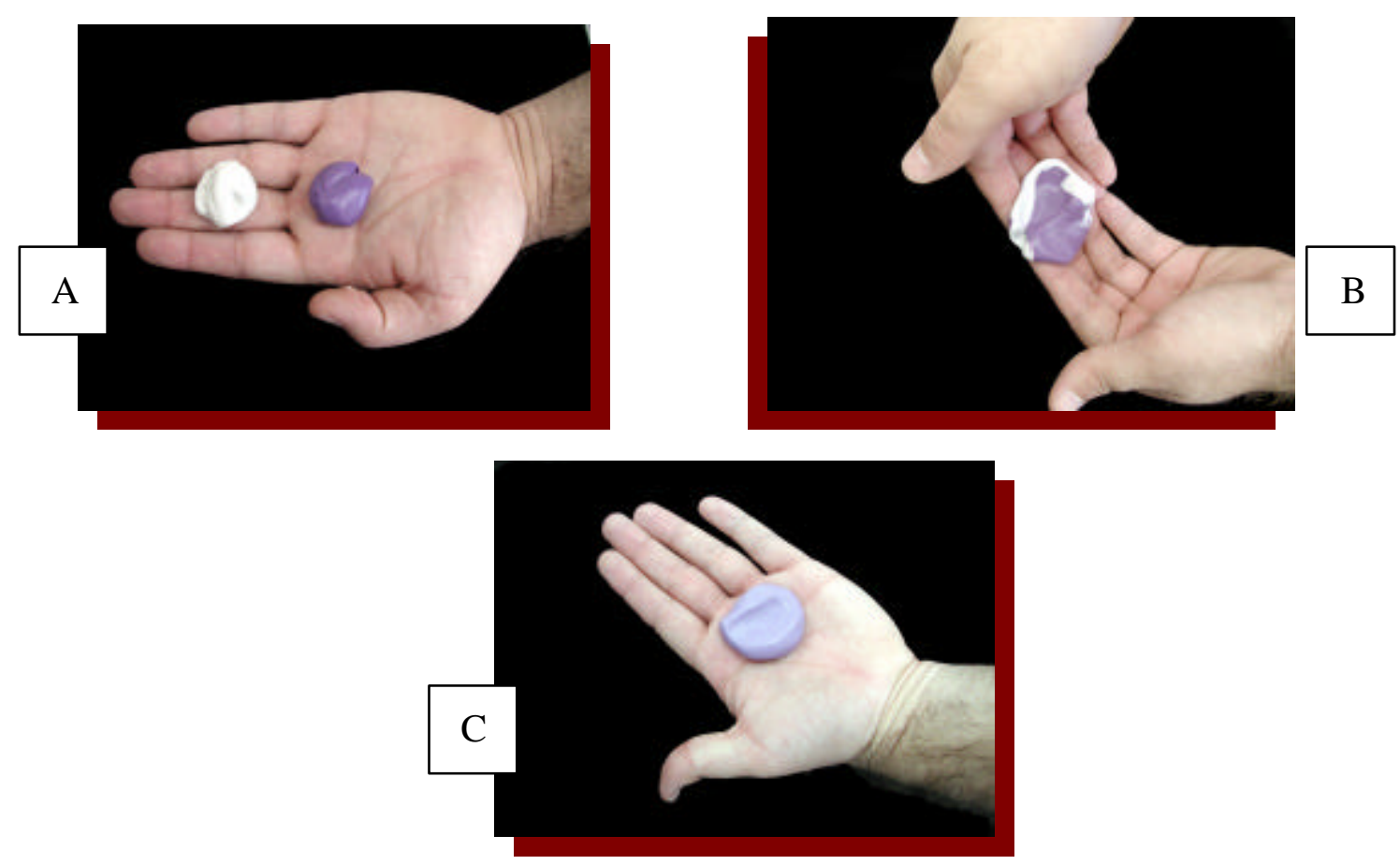

Figura 4.6 A, B e C - Manipulação das duas pastas base da silicona de adição (A), sem o uso de luvas (B), até a obtenção de uma mistura homogênea (C). 
Obtida uma mistura homogênea, as luvas de procedimento eram colocadas e o material era levado para a boca do paciente sem o uso de moldeiras (Figura 4.7 A, B e C). Atenção especial era dada à região retromolar, para que o material de moldagem se adaptasse bem àquela região, respeitando-se os seguintes limites na moldagem: distal da coroa do segundo pré-molar até a região retromolar (Figura 4.7 C).

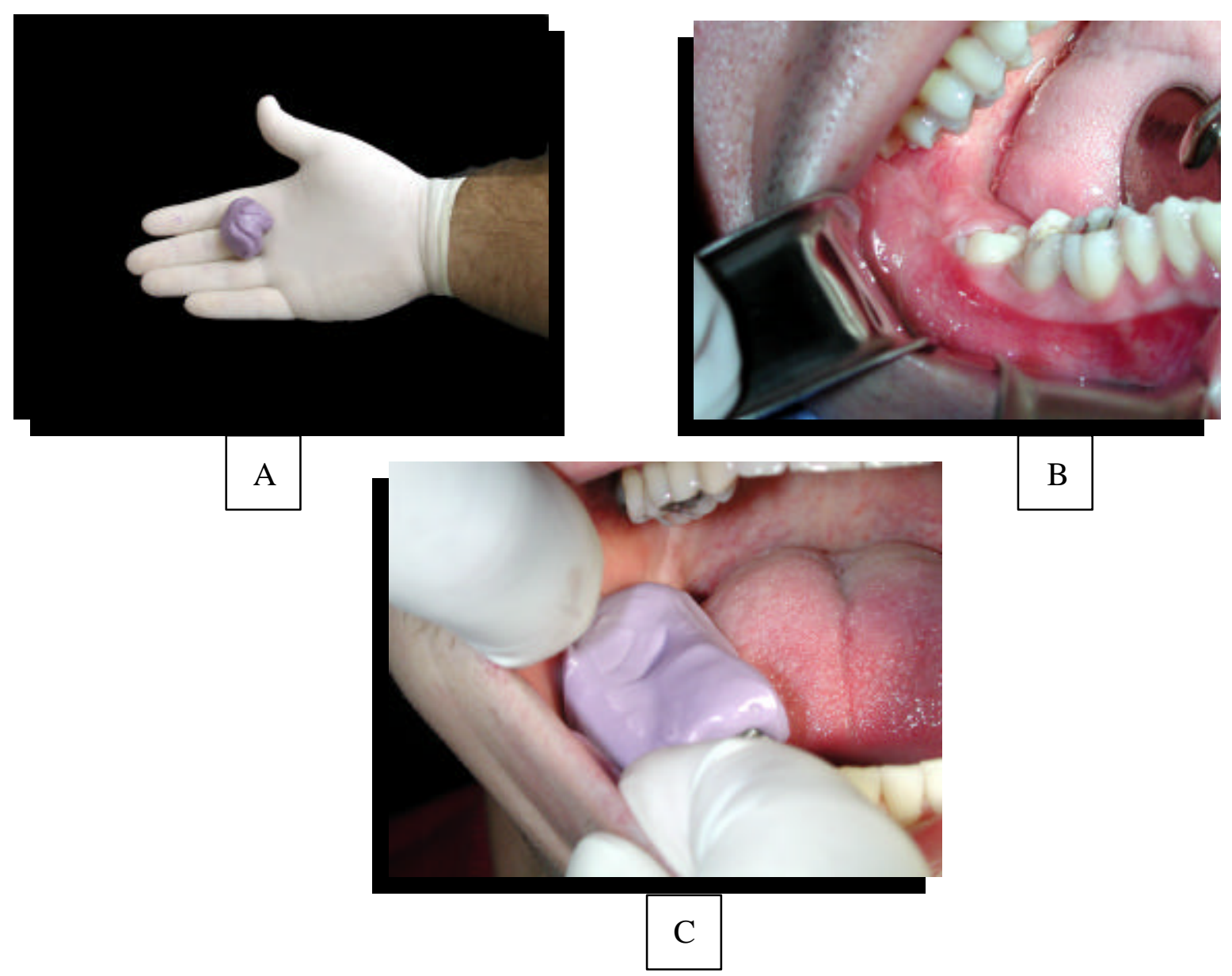

Figura 4.7 A, B e C - (A)Calçamento de luvas para a primeira moldagem. (B)Visão da área a ser moldada, notar o terceiro molar parcialmente irrompido. (C)Aplicação do material de moldagem sobre o terceiro molar e o trígono retromolar. 
Após a polimerização, o material era removido da boca do paciente, lavado em água corrente por cerca de 1 minuto e imerso em solução de Glutacide® durante o tempo mínimo de 30 minutos (Figura 4.8 A e B).

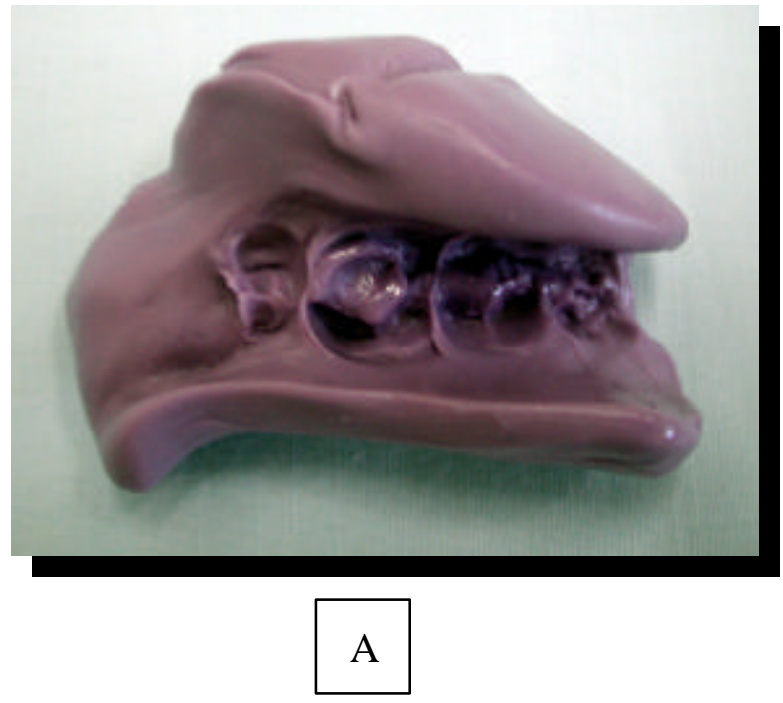

Figura 4.8 A e B - (A)Resultado final da primeira moldagem. (B) Colocação do molde na solução de Glutacide®.

\subsection{5 - Desinfecção, montagem da mesa cirúrgica e anti-sepsia.}

Para a desinfecção da mesa cirúrgica, dos tubetes de anestésico e do misturador automático da silicona de adição, foi utilizada gaze embebida em álcool $77 \%$ e friccionada sobre as superfícies durante 3 minutos ${ }^{40}$.

Realizada a desinfecção das superfícies, o cirurgião era paramentado, com gorro, máscara, jaleco ou avental limpo e óculos de 
proteção. A lavagem das mãos do cirurgião era feita com solução de clorexidina $2 \%$ (Clorohex $\left.{ }^{\circledR}\right)$ e calçavam-se luvas cirúrgicas de látex esterilizadas.

Sobre a mesa desinfetada era colocava-se um campo cirúrgico descartável esterilizado de $50 \mathrm{~cm}$ x $50 \mathrm{~cm}$. Sobre este campo o instrumental cirúrgico era colocado, conforme a metodologia proposta pela Disciplina de Cirurgia da Faculdade de Odontologia de Bauru - Universidade de São Paulo. Sobre esta mesa, ainda, eram colocados o misturador e dispensador automático da silicona de adição, desinfetado previamente.

Após a montagem da mesa, o paciente era chamado da sala de espera e feita sua anti-sepsia intrabucal com bochecho de Listerine ${ }^{\circledR}$ por 30 segundos. Em seguida, fazia-se a anti-sepsia da face com gaze embebida em solução de Sterylderm ${ }^{(G l u c o n a t o ~ d e ~ C l o r e x i d i n a ~ 20 \%), ~ p r e s a ~ e m ~ p i n c ̧ a ~}$ do tipo Allis. Colocava-se, então, um campo cirúrgico fenestrado de $1 \mathrm{~m}$ x $1 \mathrm{~m}$ sobre a face do paciente. Neste momento o auxiliar posicionava o paciente adequadamente para o cirurgião, e, a seguir, realizava os procedimentos de lavagem das mãos e calçamento das luvas. 


\subsection{6-Cirurgia}

\subsubsection{1 - $\underline{\text { Anestesia }}$}

Para o bloqueio do nervo alveolar inferior era utilizada a técnica direta, que consiste em:

Palpação do trígono retromolar para identificação do ramo ascendente da mandíbula e a inserção do músculo pterigóideo medial.

Estabelecimento do ponto da punção no trígono retromolar, cerca de $1 \mathrm{~cm}$ acima do plano oclusal dos dentes inferiores.

A seringa é posicionada na altura do segundo prémolar do lado oposto ao que deve ser anestesiado.

Punção e introdução da agulha até tocar o osso, devendo recuar aproximadamente $1 \mathrm{~mm}$ realizando a injeção do anestésico vagarosamente.

Punção sobre o ramo ascendente da mandíbula ao nível do terceiro molar para o bloqueio do nervo bucal.

Esperávamos, então, a dessensibilização dos nervos alveolar inferior, bucal e lingual, confirmado pela perda de sensibilidade nos lábios, língua e dentes inferiores do lado anestesiado. 


\subsubsection{2 - $\underline{\text { Incisão e retalho }}$}

Com a dessensibilização dos nervos alveolar inferior, bucal e lingual devidamente comprovada, procedia-se à incisão. Foi utilizada, neste trabalho, a incisão em envelope com incisão oblíqua relaxante ${ }^{41,42,49,50,51}$ (Figura 4.9), que consiste em:

Incisão sobre o ramo ascendente da mandíbula de 1 a $1,5 \mathrm{~cm}$, a partir da coroa do segundo molar até a face distal do segundo molar em sua porção média.

Incisão intra-sulcular na vestibular do segundo molar, envolvendo a papila gengival mesial deste dente.

Incisão oblíqua da papila gengival mesial do segundo molar até o fundo de sulco vestibular.
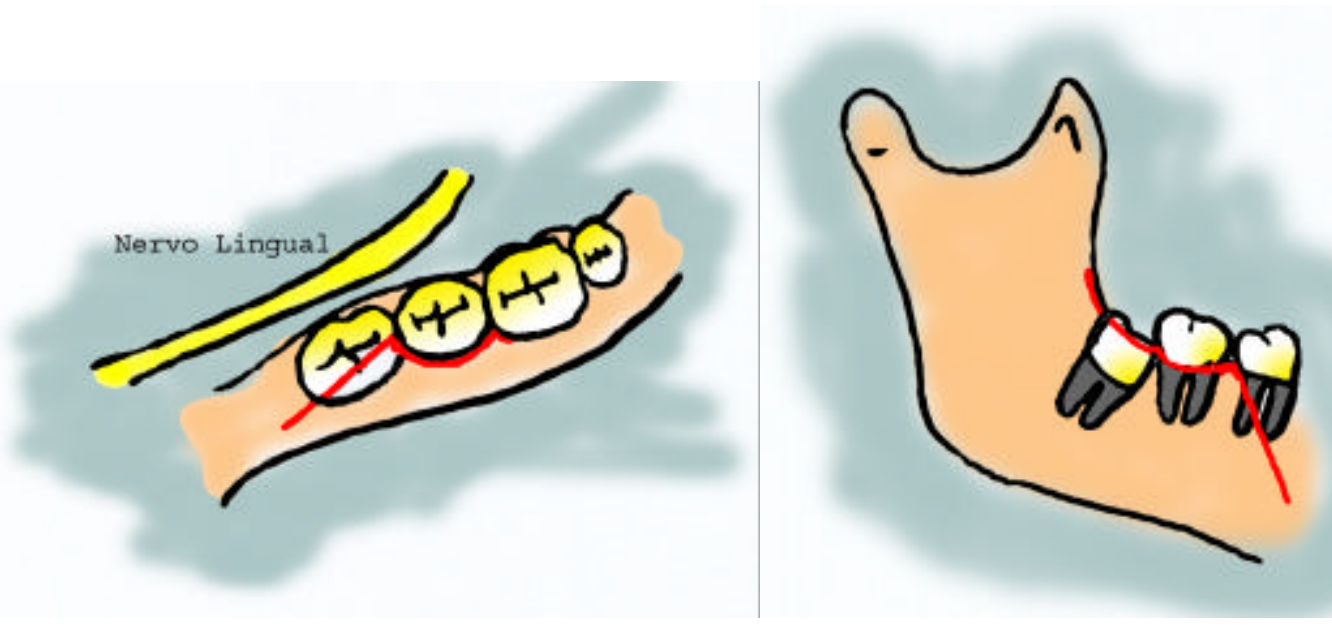

Figura 4.9 - Esquema da incisão (em vermelho) utilizada vista a partir do plano oclusal (figura à esquerda), e da incisão oblíqua (figura à direita) feita a partir da primeira incisão. 
Caso o terceiro molar estivesse total ou parcialmente irrompido, a primeira incisão foi feita até o encontro da coroa deste dente, continuando a incisão intra-sulcular desde o terceiro molar, envolvendo a papila gengival mesial do terceiro molar e prosseguindo com a incisão descrita anteriormente (Figura 4.10 A).

Com o descolador, ou destaca periósteo, de Molt n. ${ }^{\circ}$, procedeu-se ao descolamento do retalho gengival total (mucosa e periósteo), expondo-se o osso mandibular adjacente (Figura 4.10 B).

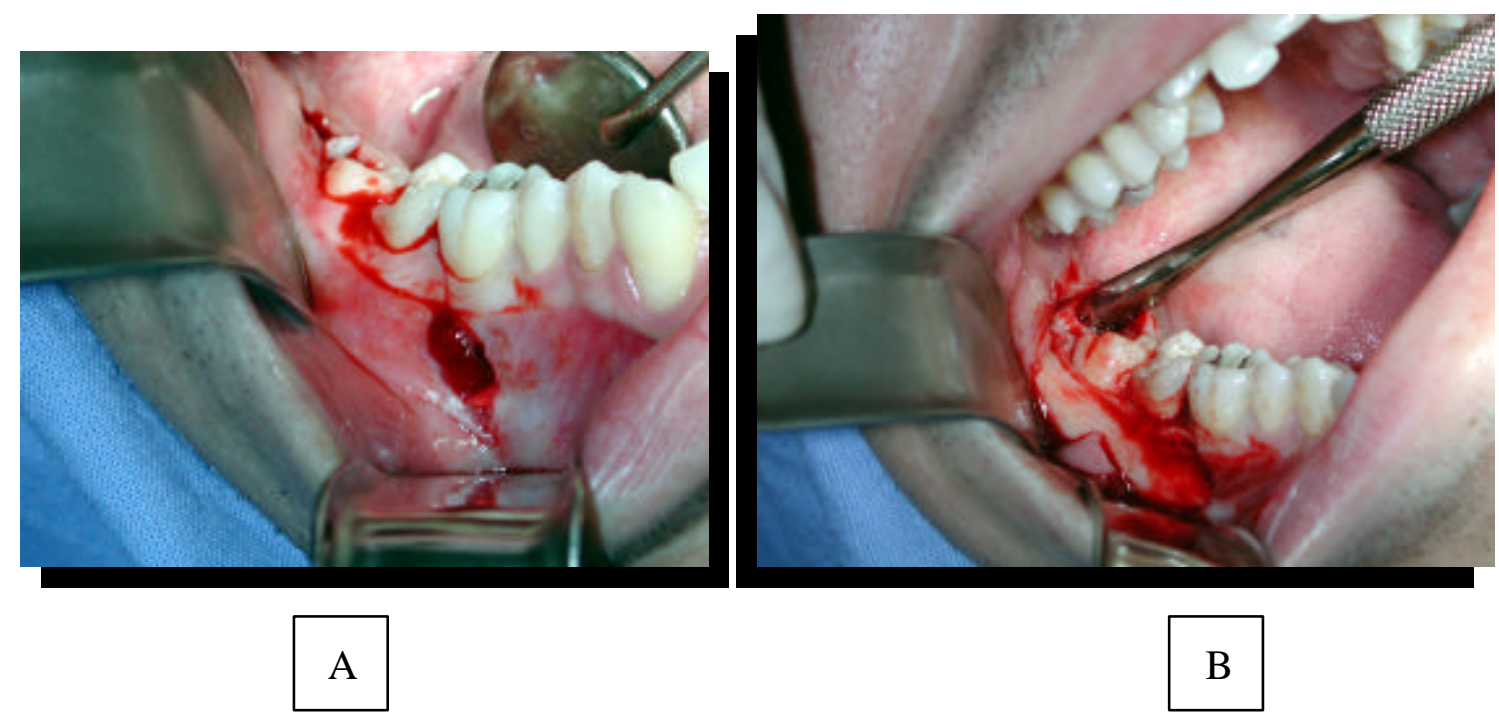

Figura 4.10 A e B - (A) Incisão. (B) Retalho mucoperiostal descolado.

\subsubsection{3 - Ostectomia}

A ostectomia tem a função de retirar tecido ósseo que, por ventura, esteja impedindo a remoção do dente. Esse tecido ósseo normalmente está acima do equador protético do dente e na face distal. Para 
esta pesquisa, ela também tem a função de facilitar a moldagem da porção cervical do terceiro molar.

A ostectomia foi realizada nos casos onde não observamos a exposição da furca do terceiro molar ou da junção amelocementária após o rebatimento do retalho e foram realizadas com brocas do tipo carbide $n^{\circ} .6$ ou 8 , de haste longa, sob alta rotação e devidamente refrigeradas com água destilada pela própria caneta de alta rotação.

Feita a proteção do retalho lingual com o uso de uma espátula $\mathrm{n}^{\circ} .7$, e do retalho vestibular com o afastador de Minessota, realizavase a ostectomia nas faces vestibular e distal. Procurava-se remover todo o osso cortical da mandíbula circundante ao terceiro molar (Figuras 4.11 A e B, e 4.12).
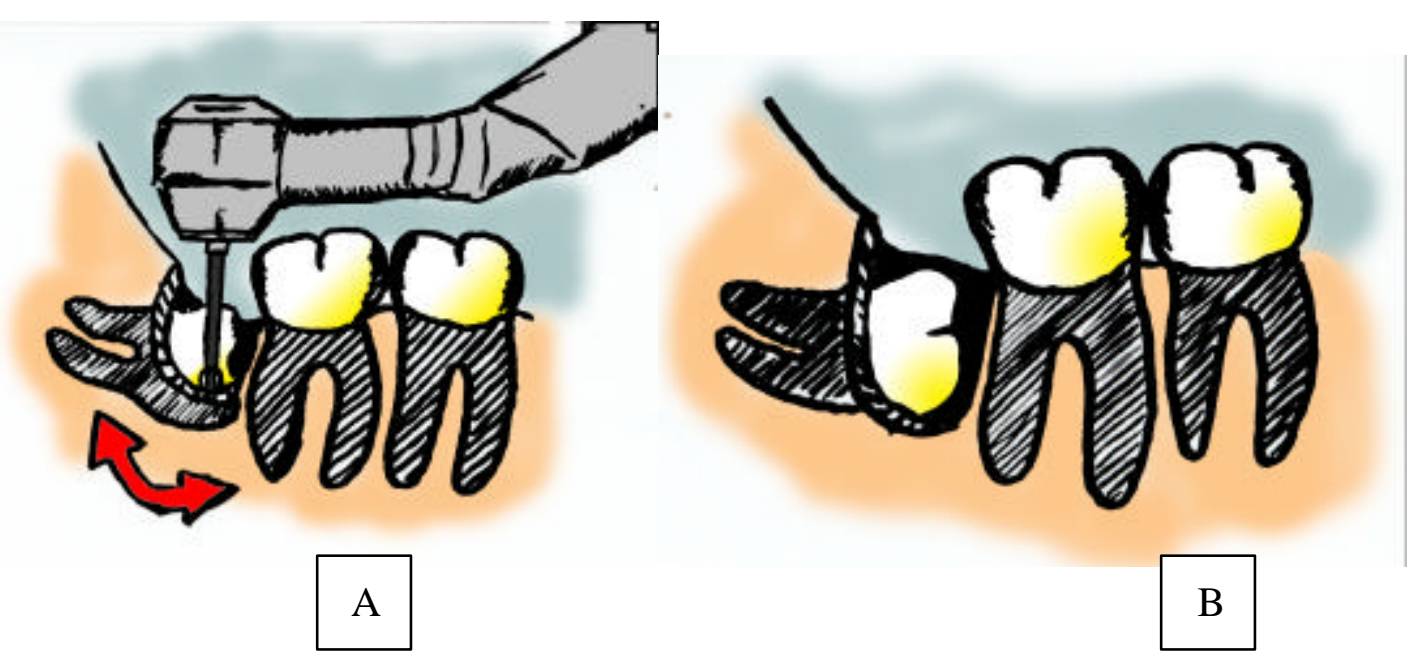

Figura 4.11 A e B - (A)Esquema de uma ostectomia evidenciando, em vermelho, o movimento que se faz durante a execução da mesma. (B)Término da exposição da coroa do terceiro molar após a ostectomia. 


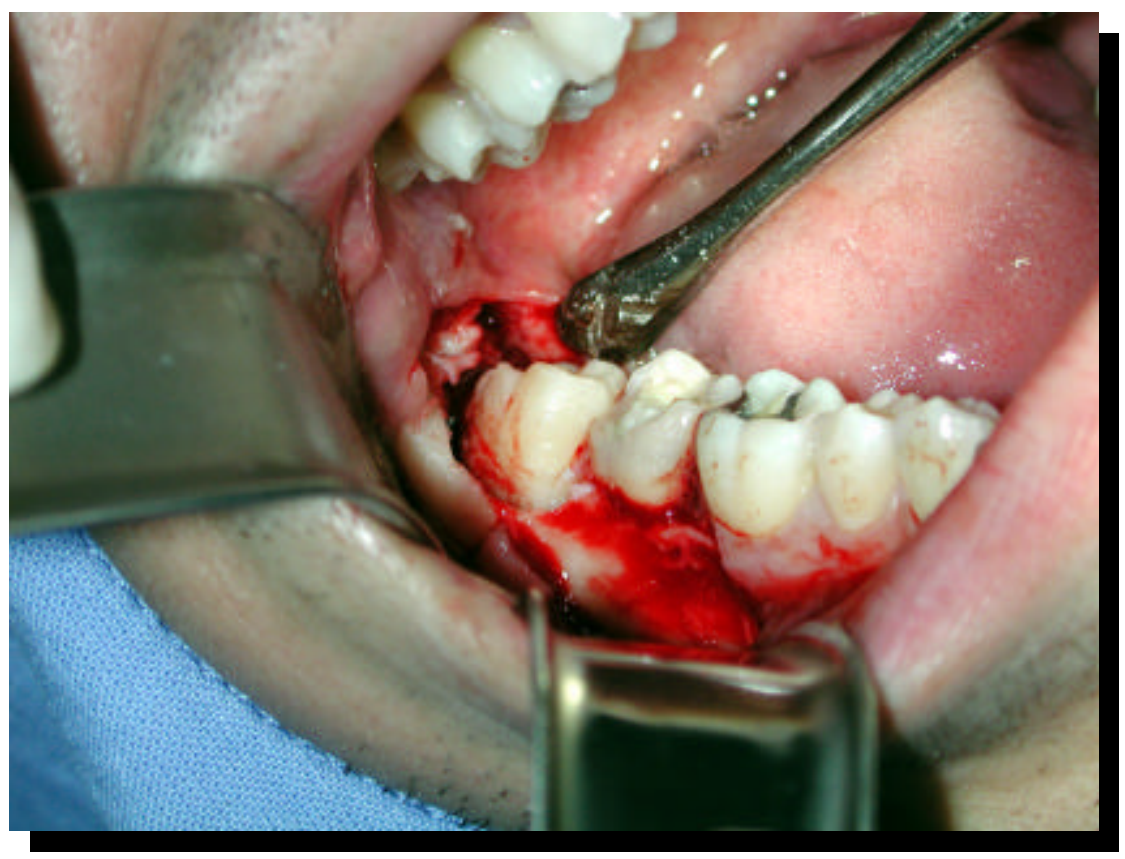

Figura 4.12 - Ostectomia concluída. Notar total exposição da coroa do terceiro molar inferior.

\subsection{7- Segunda moldagem}

Depois da exposição da coroa do terceiro molar a ser extraído, colocava-se uma gaze úmida com soro fisiológico sobre o retalho.

Retirava-se o molde do paciente $\left(1^{\mathrm{a}}\right.$ moldagem $)$ da solução de Glutacide®, e, com o auxílio de uma terceira pessoa paramentada que não atuava no campo cirúrgico, este molde era lavado com soro fisiológico corrente e seco, utilizando-se de gaze esterilizada.

A gaze que estava sobre o retalho era então removida, o auxiliar aspirava o sangue presente, deixando o campo cirúrgico o mais seco e 
limpo possível. O cirurgião, com o uso do misturador e dispensador automático, colocava o material de moldagem mais fluido sobre o molde (Figura 4.13 A) e sobre o terceiro molar a ser extraído (Figura 4.13 B), sendo o molde colocado novamente em posição, aguardando o tempo de polimerização (3 a 5 minutos) (Figura $4.13 \mathrm{C}$ ).

Após a polimerização do material, o molde era removido e verificava-se a necessidade de nova moldagem (Figura 4.13 D).

Durante todo este procedimento, o retalho era protegido e afastado da mesma forma e pelos mesmos instrumentos utilizados nos casos em que a ostectomia foi realizada.

Constatada a correta moldagem da área, o retalho e o osso mandibular eram abundantemente irrigados com soro fisiológico em seringa Luer-Loc com cânulas de irrigação. Nesta etapa, cuidados especiais foram tomados para que não houvesse nenhum problema decorrente da permanência de restos de material de moldagem, pois sabe-se que os principais problemas que este material de moldagem pode causar relacionam-se com restos deixados durante a moldagem ${ }^{52}$ (Figura 4.13 E).

O molde era então colocado sobre a mesa cirúrgica coberto com gazes embebidas em soro fisiológico. 

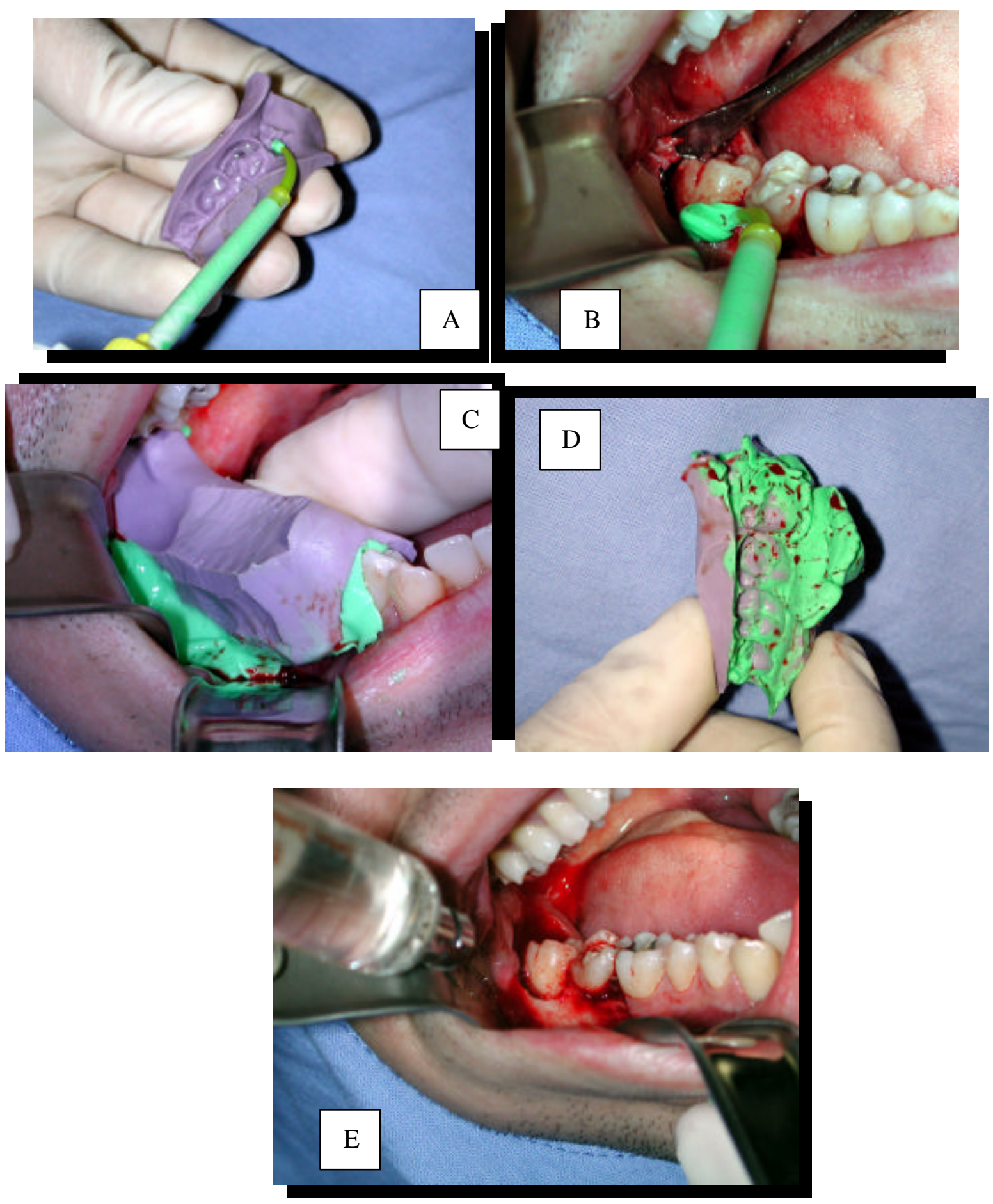

Figura 4.13 A, B, C, D e E - (A e B) Aplicação do material de moldagem leve sobre o molde e dente respectivamente. (C e D) Moldagem trans-cirúrgica e resultado final desta moldagem respectivamente. (E) Irrigação com soro fisiológico no local da moldagem. 


\subsection{8- Continuação da cirurgia}

A cirurgia prosseguiu, de acordo com os protocolos propostos pelas Disciplinas de Cirurgia da Faculdade de Odontologia de Bauru - Universidade de São Paulo.

\subsection{9-Medicação e cuidados pós-operatórios}

\subsubsection{1 - Medicação pós-operatória}

Seguindo o esquema terapêutico proposto pela disciplina de Cirurgia da Faculdade de Odontologia de Bauru - Universidade de São Paulo, para os pacientes que se submeteram à ostectomia em qualquer um dos dentes extraídos (superior ou inferior), foi prescrito antibioticoterapia com derivados de penicilina (Amoxicilina 500mg), durante 5 dias no pós-operatório. No caso de o paciente ser alérgico à penicilina, o antibiótico de escolha seria a Eritromicina 500mg, pelo mesmo período de tempo.

Em todos os pacientes foi feita terapia antiinflamatória por 3 dias, com a utilização da Nimesulida 100mg ou Diclofenaco Potássico 50mg, complementando com prescrição de analgésico (Dipirona Sódica) em gotas, se necessário. 


\subsubsection{2 - Cuidados pós-operatórios}

Todos os pacientes recebiam um folheto impresso com as recomendações pós-operatórias propostas pela disciplina de Cirurgia da Faculdade de Odontologia de Bauru - Universidade de São Paulo (ANEXO 6), complementadas com explicações do pesquisador.

Dentre os principais cuidados, foram destacados: repouso no pós-operatório imediato; alimentação líquida ou pastosa fria; higiene adequada da área; não realização de bochechos durante 3 dias; necessidade do uso correto da medic ação prescrita.

Não houve nenhum caso de alveolite pós-operatória ou qualquer outro tipo de intercorrência nas 19 cirurgias realizadas com moldagens do leito cirúrgico com siliconas de adição.

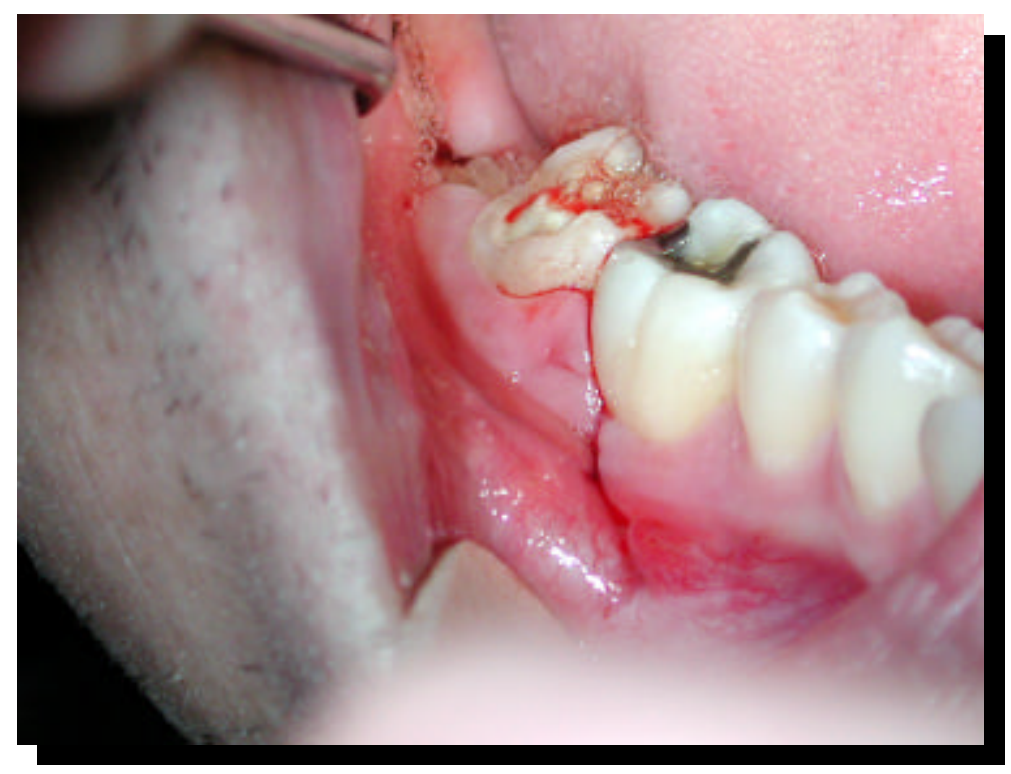

Figura 4.14 - Pós-operatório de 1 semana após a remoção da sutura. 


\subsubsection{0-Confecção dos modelos de gesso}

Depois de o molde ser devidamente limpo e desinfetado, era confeccionado o modelo de gesso tipo IV (Durone $\left.{ }^{\circledR}\right)$.

O gesso era proporcionado em uma relação água/pó de 1/4 e espatulado vigorosamente em gral de borracha com a utilização de espátula de gesso ${ }^{7,52} . \mathrm{O}$ gesso ainda fluido era colocado sobre o molde, com o auxílio de um vibrador, com o objetivo de evitar a formação de bolhas no modelo.

Após a reação de presa do gesso (aproximadamente 40 minutos), o modelo era removido do molde e este era desprezado (Figura 4.15).

$$
\text { O modelo de gesso era identificado em sua porção }
$$

inferior com o nome do paciente e a data em que foi realizada a moldagem.

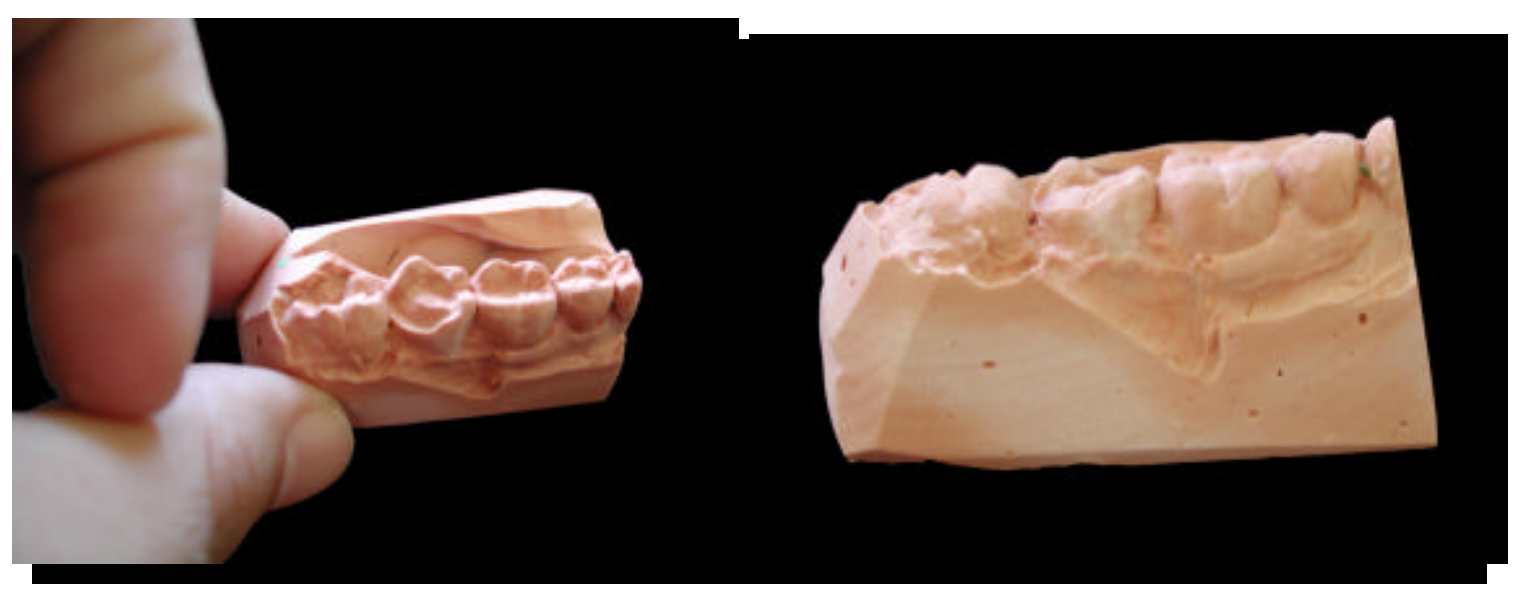

Figura 4.15 - Modelo de gesso obtido a partir da moldagem trans-cirúrgica. 


\subsubsection{1 - Obtenção das medidas nos modelos de gesso e radiografia}

\section{panorâmica}

A angulação do terceiro molar inferior na radiografia panorâmica era determinada pela relação do plano sagital entre o terceiro e o segundo molar, obtida a partir de um traçado feito em papel vegetal colocado sobre a radiografia panorâmica (Figura 4.16 A). Uma linha era traçada a partir do ponto médio da superfície oclusal do dente até a bifurcação das raízes, representando o longo eixo destes dentes (Figura 4.16 A). O ângulo formado a partir da intersecção dos dois longos eixos correspondia ao grau de inclinação do terceiro molar inferior (Figura 4.16 B).

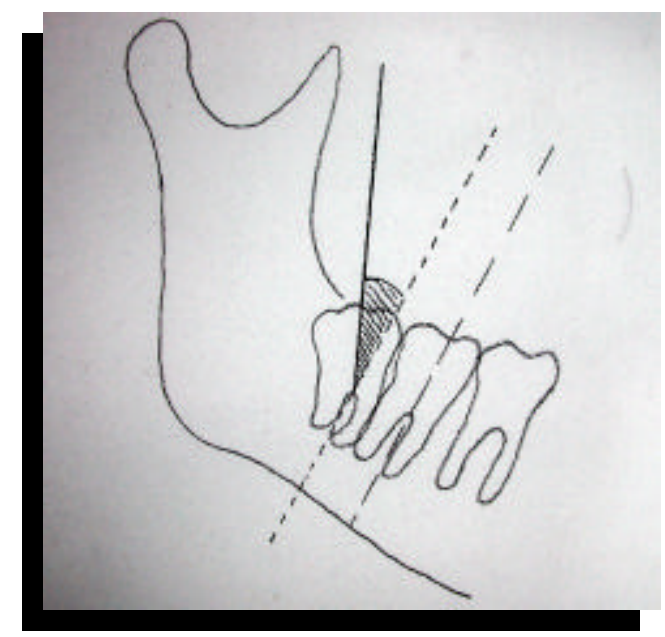

$\mathrm{A}$

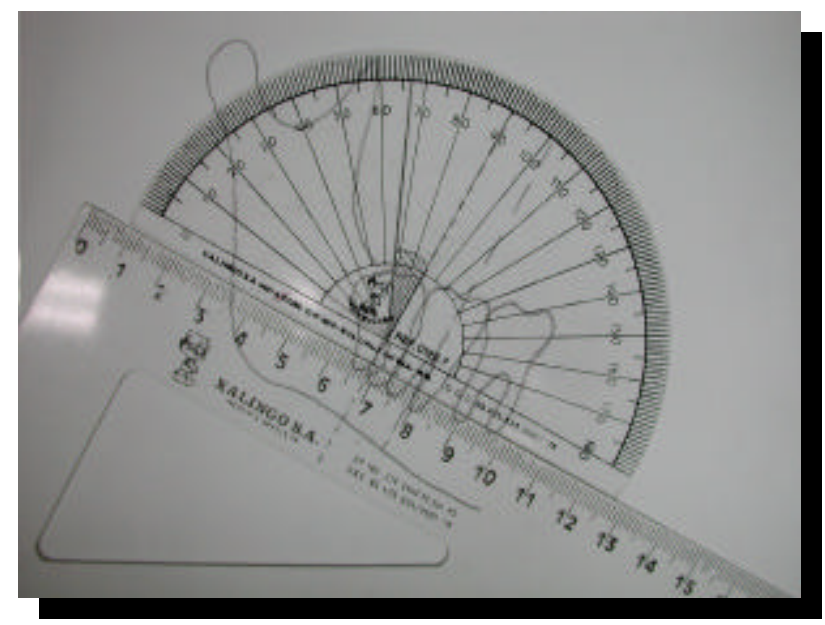

$\mathrm{B}$

Figura 4.16 A e B - Obtenção das medidas a partir do traçado da radiografia panorâmica.

Após a reação de presa do gesso, era feito o refinamento dos modelos, obtido nas moldagens trans-cirúrgicas, nos recortadores. Este 
procedimento tinha como finalidade a remoção de áreas que impedissem a adaptação correta do dispositivo para obtenção de medidas nos modelos de gesso.

Quando os modelos de gesso estavam devidamente preparados, eram feitas as medidas seguindo os seguintes passos:

Marcação do longo eixo do segundo molar com um traço de lápis preto $n .^{\circ}$, desde a região mediana da cervical do dente até o final do sulco vestibular (parte central entre as duas cúspides vestibulares) $^{21}$ (Figura 4.17).

*Marcação do longo eixo do terceiro molar, da mesma maneira que se fez a marcação do segundo molar, se o terceiro molar possuir duas cúspides vestibulares. Caso o terceiro molar possuísse 3 cúspides vestibulares, a marcação do longo eixo era feita desde a região mediana na cervical do dente até a ponta da cúspide mediana do terceiro molar(Figura 4.17).

Adaptação das duas pontas metálicas no longo eixo do segundo molar, pois assim tinha-se a certeza de que a parte vertical da base "L" estava paralela ao longo eixo do segundo molar (Figura 4.18).

Adaptação da ponta metálica da base vertical sobre a região mediana da cervical do terceiro molar (Figura 4.18). 
+Verificação do valor do ângulo correspondente à marca no longo eixo do terceiro molar, denominado X (Figura 4.18).

+Uso da equação $\mathrm{X}-90^{\circ}=\mathrm{Y}$, onde $\mathrm{Y}$ é o valor do ângulo formado entre o segundo e o terceiro molar. Utiliza-se esta equação como compensação de medidas, pois o que seria correspondente a $0^{\circ}$ entre os dentes (paralelismo) coincide com a marcação de $90^{\circ}$ do transferidor.

+Aplicar os parâmetros propostos por HATAAB ${ }^{28}$, e classificar o dente segundo WINTER ${ }^{76}$ (Figura 4.19).

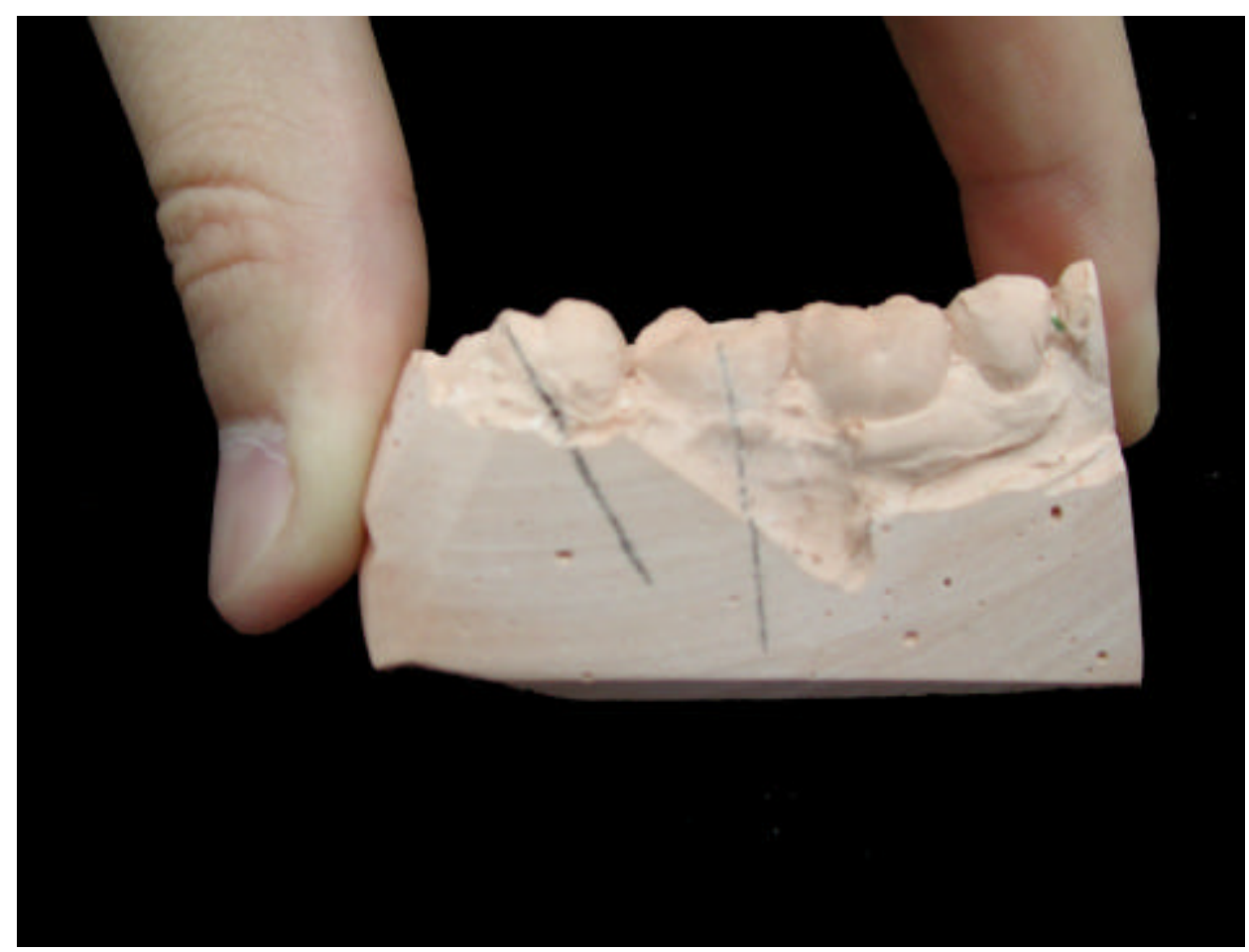

Figura 4.17 - Traçado dos longos eixos do segundo e terceiro molares no modelo de gesso. 


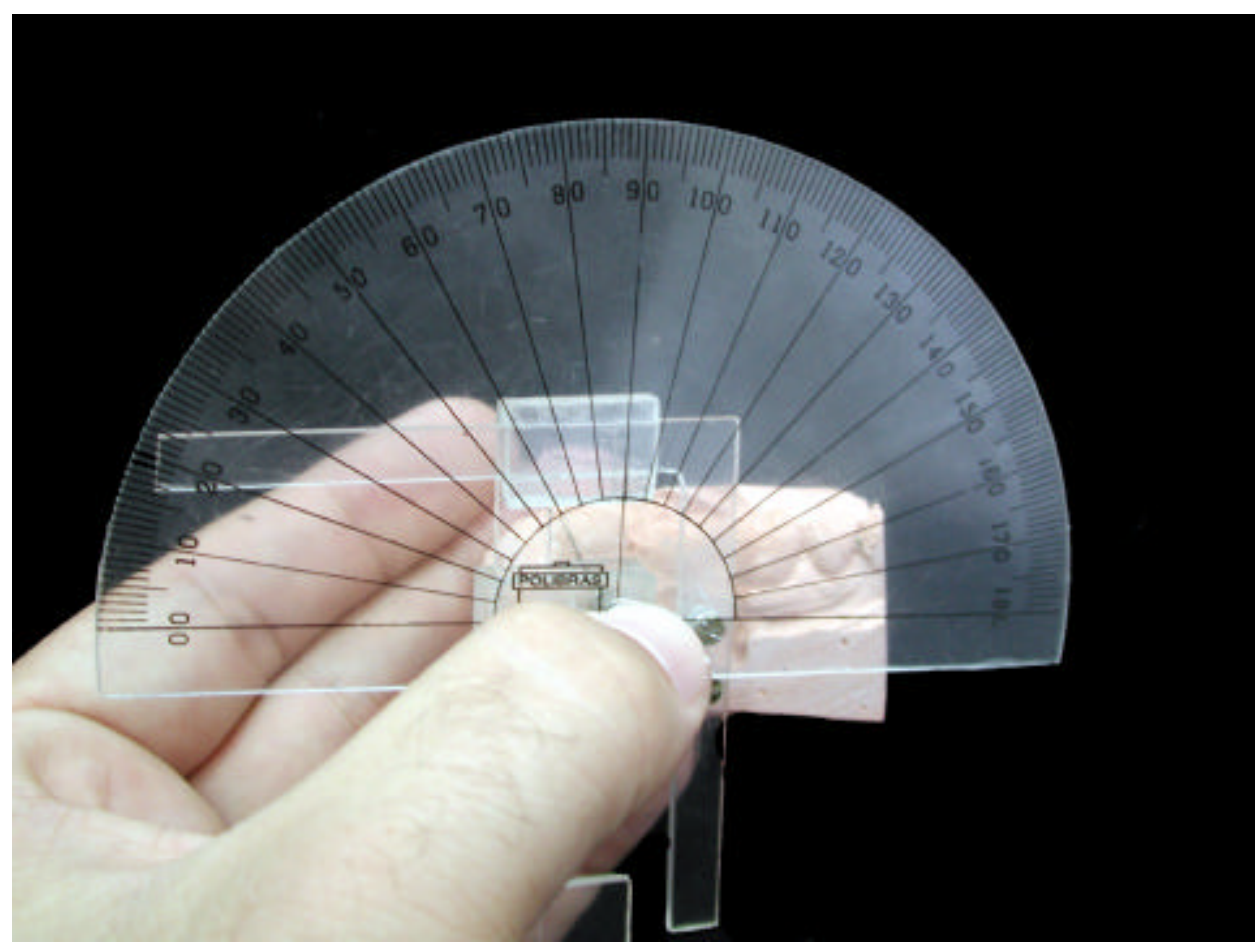

Figura 4.18- Obtenção das medidas no modelo de gesso com o uso do dispositivo.

\subsubsection{2 - Preenchimento da ficha e comparação dos valores}

Obtidos os valores dos ângulos formados entre o terceiro e o segundo molar, no modelo de gesso e na radiografia, estes valores eram anotados na ficha elaborada para esta pesquisa (Anexo 5). 
Ao lado de cada valor obtido nas medidas dos ângulos era anotada a classificação de WINTER $^{76}$, de acordo com os parâmetros propostos por HATTAB ${ }^{28}$.
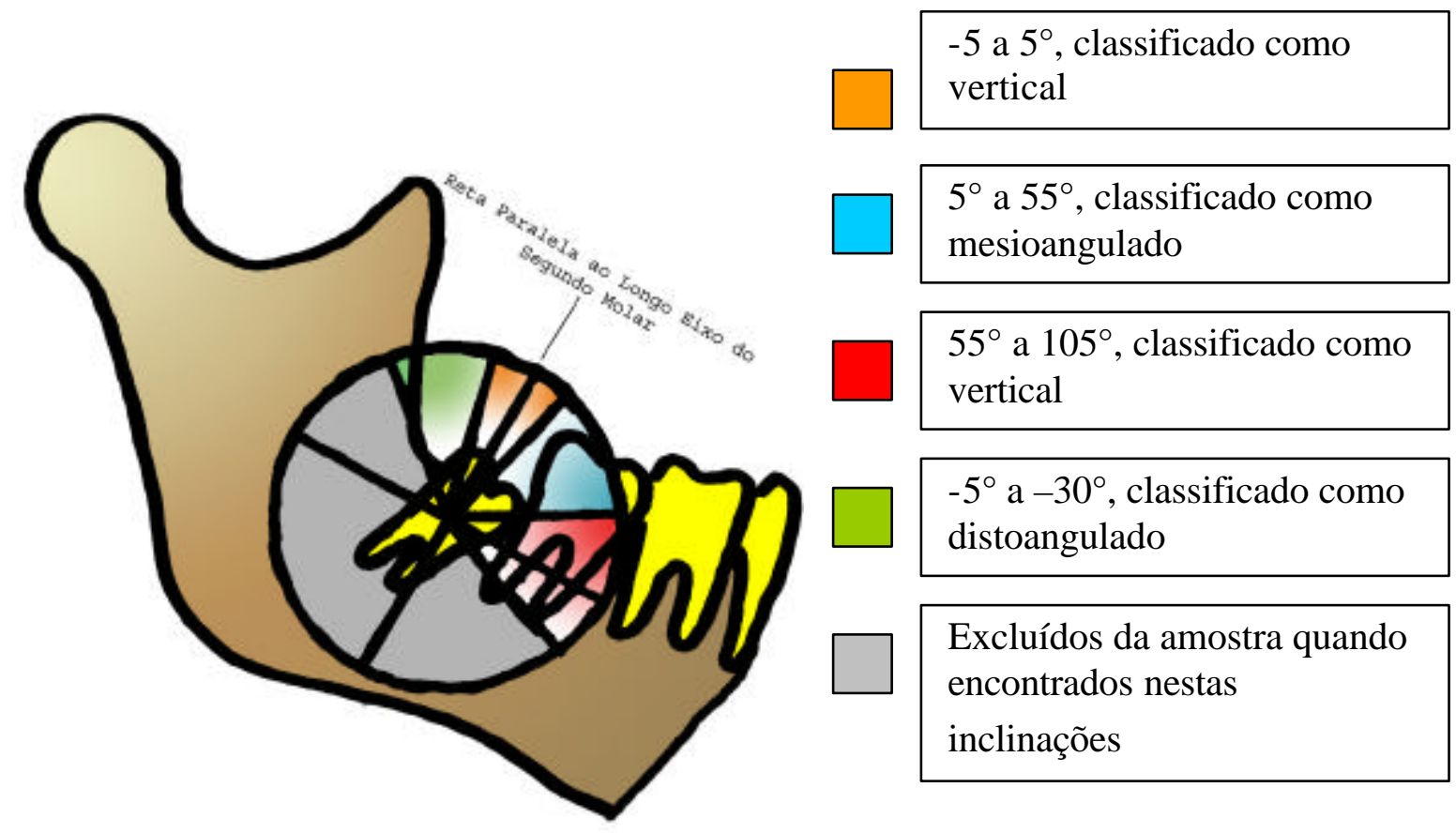
$-5^{\circ} \mathrm{a}-30^{\circ}$, classificado como distoangulado

Excluídos da amostra quando encontrados nestas inclinações

Figura 4.19 - Parâmetros angulares propostos por HATAAB ${ }^{28}$ para a classificação dos terceiros molares inferiores.

Nesta mesma ficha, havia um espaço para a anotação da variação dos ângulos e para o sentido da alteração. Se a alteração ocorria na direção mesial, era considerada como variação positiva; se a alteração ocorria no sentido distal, era considerada como variação negativa. 
5 - RESULTADOS 


\section{5 - RESULTADOS}

\section{1-Gênero dos pacientes}

Neste trabalho, foram atendidos 14 pacientes, sendo

$10(71 \%)$ pacientes do gênero feminino e 4 (29\%) do gênero masculino (Figura 5.1).

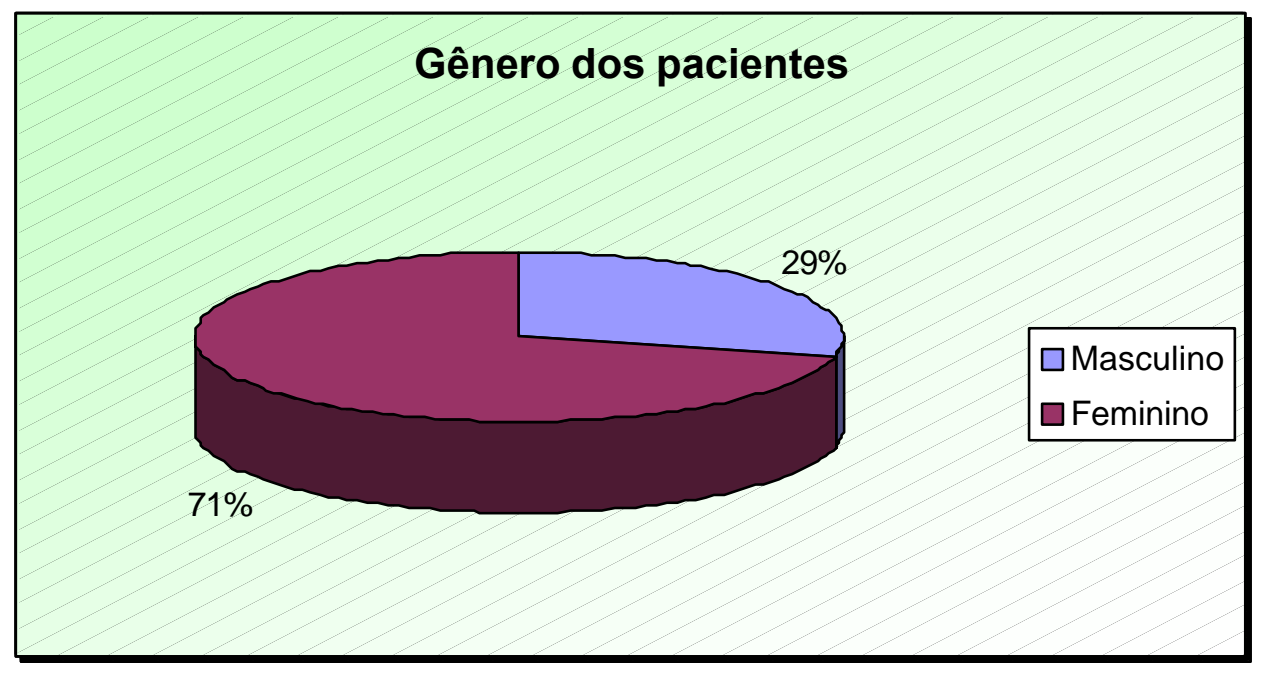

Figura 5.1 - Distribuição dos pacientes conforme o gênero. 


\section{2 - Prevalência da posição dos terceiros molares}

Foram extraídos 19 terceiros molares inferiores, sendo 11 do lado direito (48) e 8 do lado esquerdo (38).

\subsection{1 - Radiografia panorâmica}

Dos 19 terceiros molares extraídos, houve apenas 1 horizontal, segundo a classificação de WINTER $^{76}, 7$ classificados como mesioangulados, 7 verticais e 4 distoangulados, todos seguindo os parâmetros propostos por HATTAB ${ }^{28}$ (Tabela 5.1 e Figura 5.2).

Tabela 5.1 - Prevalência das posições dos terceiros molares inferiores obtidas pela interpretação das radiografias panorâmicas.

\begin{tabular}{c|c}
\hline Classificação de WINTER & $\mathrm{N}^{\circ}$. de pacientes \\
\hline Distoangulados & 4 \\
\hline Verticais & 7 \\
\hline Mesioangulados & 7 \\
\hline Horizontal & 1 \\
\hline
\end{tabular}




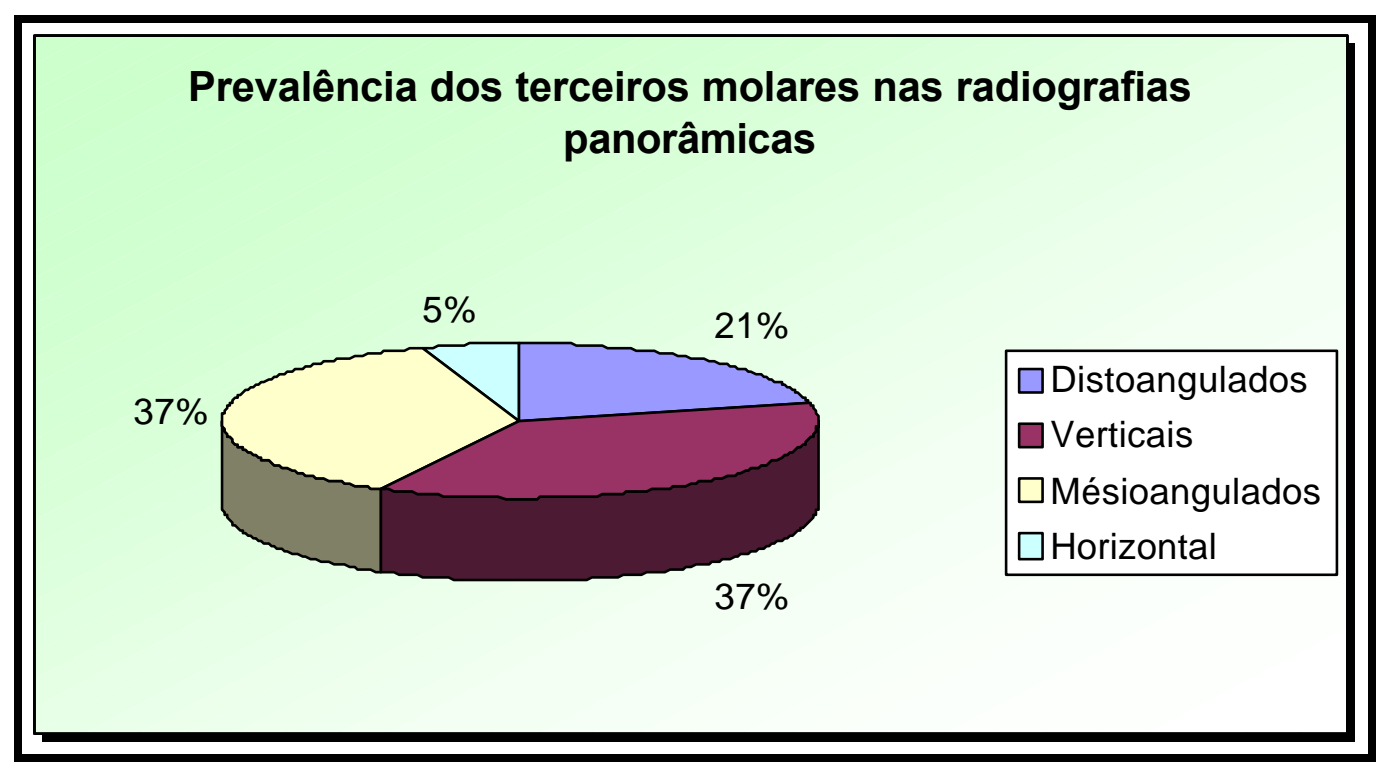

Figura 5.2 - Distribuição da prevalência das posições dos terceiros molares inferiores, obtidas através da interpretação radiográfica da radiografia panorâmica.

\subsection{2 - MODELOS DE GESSO}

Dos 19 terceiros molares extraídos, houve apenas 1 horizontal, seguindo a classificação de WINTER $^{76}, 5$ classificados como mesioangulados, 5 verticais e 8 distoangulados, todos seguindo os parâmetros propostos por HATTAB ${ }^{28}$ (Tabela 5.2 e Figura 5.3). 
Tabela 5.2 - Prevalência das posições dos terceiros molares inferiores obtidos através dos modelos de gesso.

\begin{tabular}{c|c}
\hline Classificação de WINTER & $\mathrm{N}^{\circ}$. de pacientes \\
\hline Distoangulados & 8 \\
\hline Verticais & 5 \\
\hline Mésioangulados & 5 \\
\hline Horizontal & 1 \\
\hline
\end{tabular}

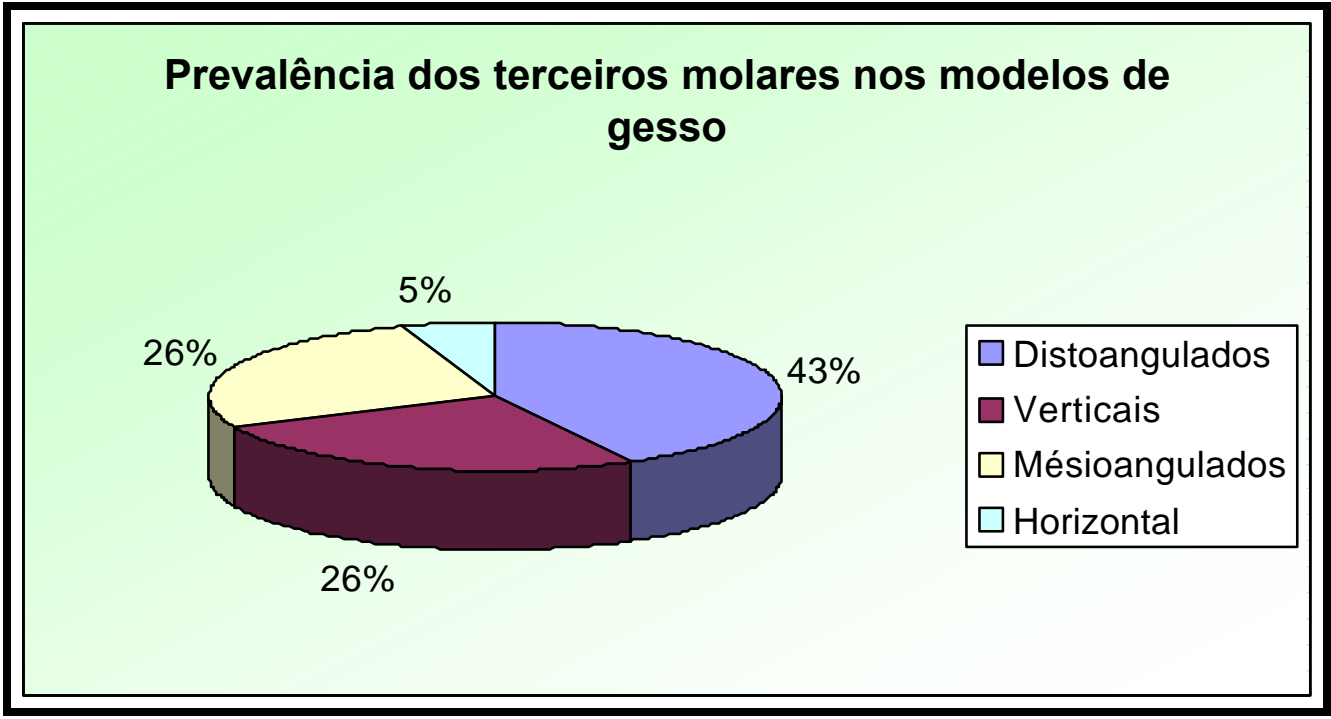

Figura 5.3 - Distribuição da prevalência das posições dos terceiros molares inferiores, obtidas através dos modelos de gesso. 


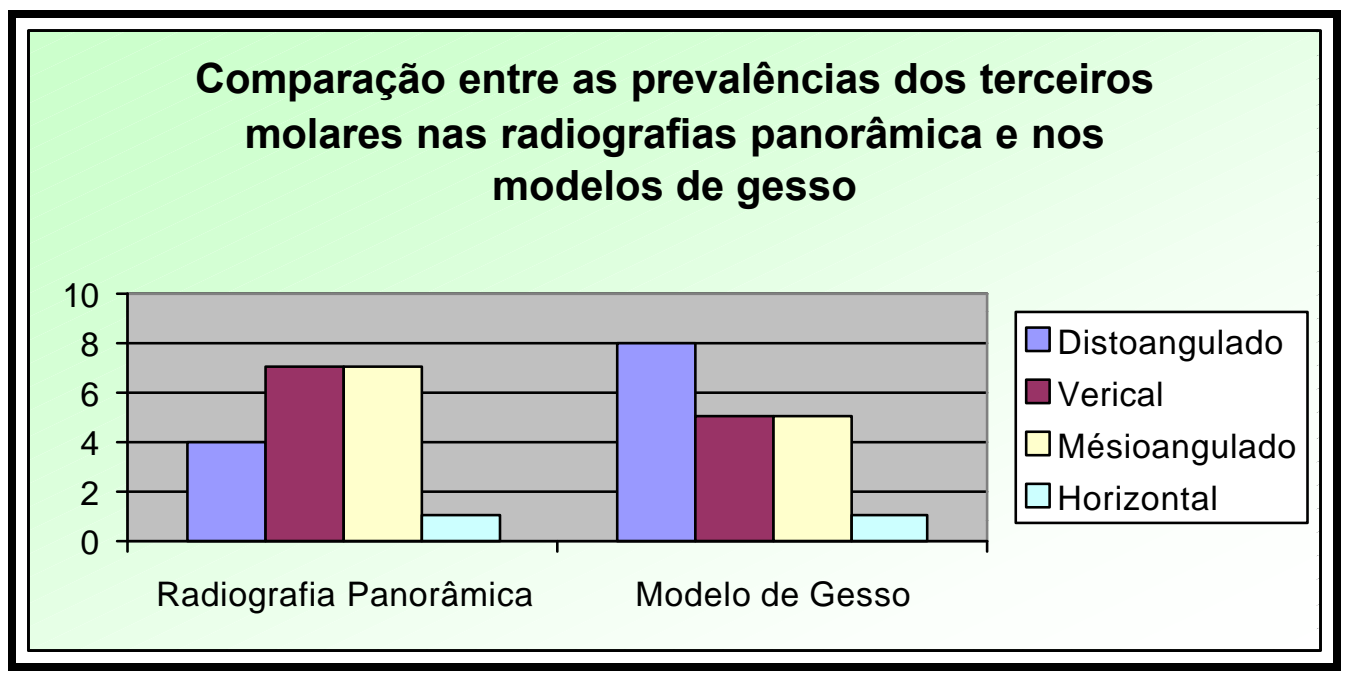

Figura 5.4 - Comparação das prevalências das posições dos terceiros molares nas radiografias panorâmicas e nos modelos de gesso.

\section{$\underline{5.3 \text { - Variação das medidas }}$}

Houve variação em todas as medidas de inclinação

dos terceiros molares nas radiografias panorâmicas e nos modelos de gesso. Em 6 casos (31,5\%), essa variação foi o suficiente para mudar a classificação do dente (Tabela 5.3).

Apenas em 1 paciente, cujos 2 terceiros molares foram extraídos, essa mudança de classificação foi bilateral, mas a quantidade de variação não foi a mesma $\left(5^{\circ}\right.$ e $\left.9^{\circ}\right)$. Em outros 3 pacientes que se submeteram a 2 cirurgias, encontramos variação angular bilateral, mas apenas 1 dos terceiros molares teve sua classificação alterada. Em outro paciente, a cirurgia foi unilateral. Em um paciente submetido a duas cirurgias, houve mudança bilateral das medidas e a mesma foi uniforme $\left(6^{\circ}\right.$ 
para o lado esquerdo e direito), mas a classificação do dente foi mantida (Tabela 5.4).

Tabela 5.3 - Pacientes submetidos à pesquisa e classificação dos dentes na radiografia panorâmica e modelos de gesso.

\begin{tabular}{|c|c|c|c|c|c|}
\hline $\begin{array}{c}\text { Pacientes } \\
\text { (Dente extr.) }\end{array}$ & $\begin{array}{l}\text { Medida } \\
\text { Radiografia }\end{array}$ & $\begin{array}{l}\text { Classificação na } \\
\text { Radiografia }\end{array}$ & $\begin{array}{l}\text { Medida no } \\
\text { Modelo }\end{array}$ & $\begin{array}{c}\text { Classificação no } \\
\text { Modelo }\end{array}$ & Variação \\
\hline M. T. V. R. (38) & 14 & Mesioangulado & 10 & Mesioangulado & -4 \\
\hline F. C. G. (48) & 8 & Mesioangulado & 3 & Vertical & -5 \\
\hline J. G. (48) & 51 & Mesioangulado & 44 & Mesioangulado & -7 \\
\hline S. V. R. (38) & 62 & Horizontal & 57 & Horizontal & -5 \\
\hline K. C. P. F. (48) & -21 & Distoangulado & -25 & Distoangulado & -4 \\
\hline (38) & -5 & Vertical & -11 & Distoangulado & -6 \\
\hline R. C. L. (38) & 45 & Mesioangulado & 41 & Mesioangulado & -4 \\
\hline A O (48) & -8 & Distoangulado & -12 & Distoangulado & -4 \\
\hline M. E. B. (48) & -19 & Distoangulado & -25 & Distoangulado & -6 \\
\hline (38) & 4 & Vertical & -2 & Vertical & -6 \\
\hline M. Z. O (38) & -5 & Vertical & -10 & Distoangulado & -5 \\
\hline (48) & 11 & Mesioangulado & 2 & Vertical & -9 \\
\hline C. P. B. (48) & 36 & Mesioangulado & 30 & Mesioangulado & -6 \\
\hline F. R. A (48) & 25 & Mesioangulado & 17 & Mesioangulado & -8 \\
\hline J. C. P. (48) & -10 & Distoangulado & -16 & Distoangulado & -6 \\
\hline A M. G. (38) & -5 & Vertical & -11 & Distoangulado & -6 \\
\hline (48) & 5 & Vertical & 1 & Vertical & -4 \\
\hline L. L.S. (38) & -3 & Vertical & -7 & Distoangulado & -4 \\
\hline (48) & 1 & Vertical & -4 & Vertical & -5 \\
\hline
\end{tabular}

As linhas destacadas em azul representam variação na classificação do terceiro molar.

Dos cinco pacientes que se submeteram a duas cirurgias, os resultados não justificaram maior distorção de um lado da radiografia panorâmica. Em um paciente a variação foi uniforme, em dois pacientes a maior distorção ocorreu no lado direito e em outros dois a distorção foi maior no lado esquerdo. Nem sempre o lado que possuiu a maior variação foi aquele em que teve sua classificação alterada. 
Tabela 5.4 - Pacientes que se submeteram a duas cirurgias.

\begin{tabular}{r|c|c|c|c|c}
\hline \multicolumn{1}{c}{$\begin{array}{c}\text { Pacientes } \\
\text { (Dente extr.) }\end{array}$} & $\begin{array}{l}\text { Med. } \\
\text { Radiografia }\end{array}$ & $\begin{array}{l}\text { Classificação na } \\
\text { Radiografia }\end{array}$ & $\begin{array}{c}\text { Medida no } \\
\text { Modelo }\end{array}$ & $\begin{array}{c}\text { Classificação no } \\
\text { Modelo }\end{array}$ & Variação \\
\hline K. C. P. F. (48) & -21 & Distoangulado & -25 & Distoangulado & -4 \\
(38) & -5 & Vertical & -11 & Distoangulado & -6 \\
\hline M. E. B. (48) & -19 & Distoangulado & -25 & Distoangulado & -6 \\
(38) & 4 & Vertical & -2 & Vertical & -6 \\
\hline M. Z. O (38) & -5 & Vertical & -10 & Distoangulado & -5 \\
(48) & 11 & Mésioangulado & 2 & Vertical & -9 \\
\hline A M. G. (38) & -5 & Vertical & -11 & Distoangulado & -6 \\
(48) & 5 & Vertical & 1 & Vertical & -4 \\
\hline L. L. S. (38) & -3 & Vertical & -7 & Distoangulado & -4 \\
(48) & 1 & Vertical & -4 & Vertical & -5 \\
\hline
\end{tabular}

Nas linhas destacadas em azul houve variação da classificação do terceiro molar entre a radiografia panorâmica e o modelo de gesso. As células destacadas em verde

correspondem ao único caso onde a variação da inclinação do terceiro molar foi equivalente. As células destacadas em amarelo correspondem ao lado do paciente onde houve maior variação.

Foi observada uma variação média das medidas angulares da radiografia panorâmica e do modelo de gesso de $5,37^{\circ}$, com desvio padrão de $1,46^{\circ}$, com seu valor máximo de $9^{\circ}$ e mínimo de $4^{\circ}$ (Figura 5.5).

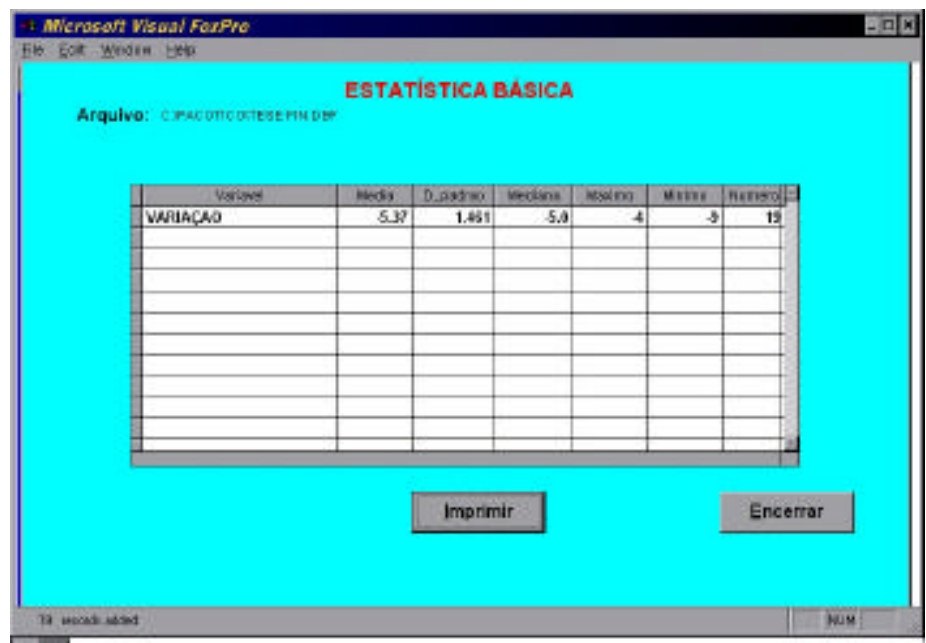

Figura 5.5 - Tela do programa PACOTICO. Realização dos cálculos de estatística básica. 
As três maiores distorções $\left(9^{\circ}, 8^{\circ}\right.$ e $\left.7^{\circ}\right)$ foram no lado direito dos pacientes, porém as médias das distorções, quando comparados o lado direito e esquerdo, são semelhantes. Para o lado direito obteve-se média de variação de medidas de $5,81^{\circ}$, enquanto que o lado esquerdo obteve $5,62^{\circ}$ (Figura 5.6).

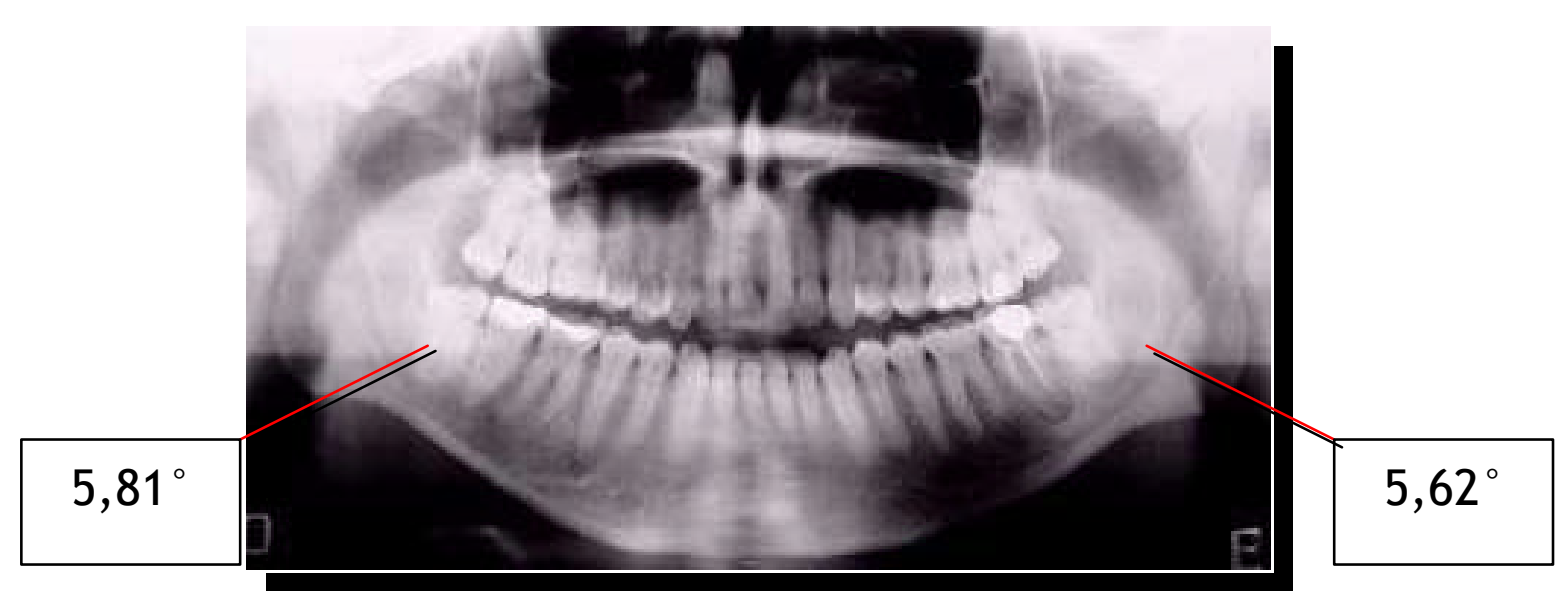

Figura 5.6 - Radiografia panorâmica, evidenciando qual a variação angular média no lado esquerdo e direito na região de terceiros molares.

\section{$\underline{5.5-\text { Análise estatística }}$}

Neste trabalho, foi utilizado para a análise estatística

o programa PACOTICO, desenvolvido pelo Prof. Dr. Eymar Sampaio Lopes, do departamento de Ortodontia, Odontopediatria e Saúde Coletiva da Faculdade de Odontologia de Bauru - Universidade de São Paulo.

Realizou-se o cálculo de estatística básica, média e desvio padrão, apenas da variação das medidas da inclinação do terceiro molar nas radiografias panorâmicas e comparação com as medidas nos modelos de 
gesso (Figura 5.5), pois como não houve uma padronização da classificação dos dentes que foram extraídos, a média e o desvio padrão das medidas na radiografia e no modelo de gesso não refletiriam uma situação real (por exemplo, dizer que, em média, os dentes seriam de alguma classificação).

Para estes dois grupos, era importante analisar se haveria diferença na medida entre eles. Então, utilizou-se o teste de dois grupos pareados de "Student", com a hipótese de que a medida dos ângulos formados entre o segundo e o terceiro molar inferior na radiografia panorâmica será sempre diferente da mesma medida do modelo de gesso (Tabela 5.6 e Figura 5.7).

Tabela 5.5 - Teste estatístico "T" de Student

\begin{tabular}{|c|c|c|c|c|c|c|c|}
\hline Radiografic & & Modelc & & Variação & & $\mathrm{t}$ & $\mathrm{p}$ \\
\hline $\begin{array}{c}X \\
9,79\end{array}$ & $\frac{\mathrm{dp}}{23,62}$ & $\frac{X}{4,32}$ & $\frac{\mathrm{dp}}{23,42}$ & $\begin{array}{c}X \\
5,37\end{array}$ & $\frac{\mathrm{dp}}{1,46}$ & 16,701 & $<0,001^{*}$ \\
\hline
\end{tabular}

Tabela 5.5 - Teste estatístico "T" de Student aplicados aos valores obtidos nas radiografias panorâmicas, modelos de gesso e variação angular. 


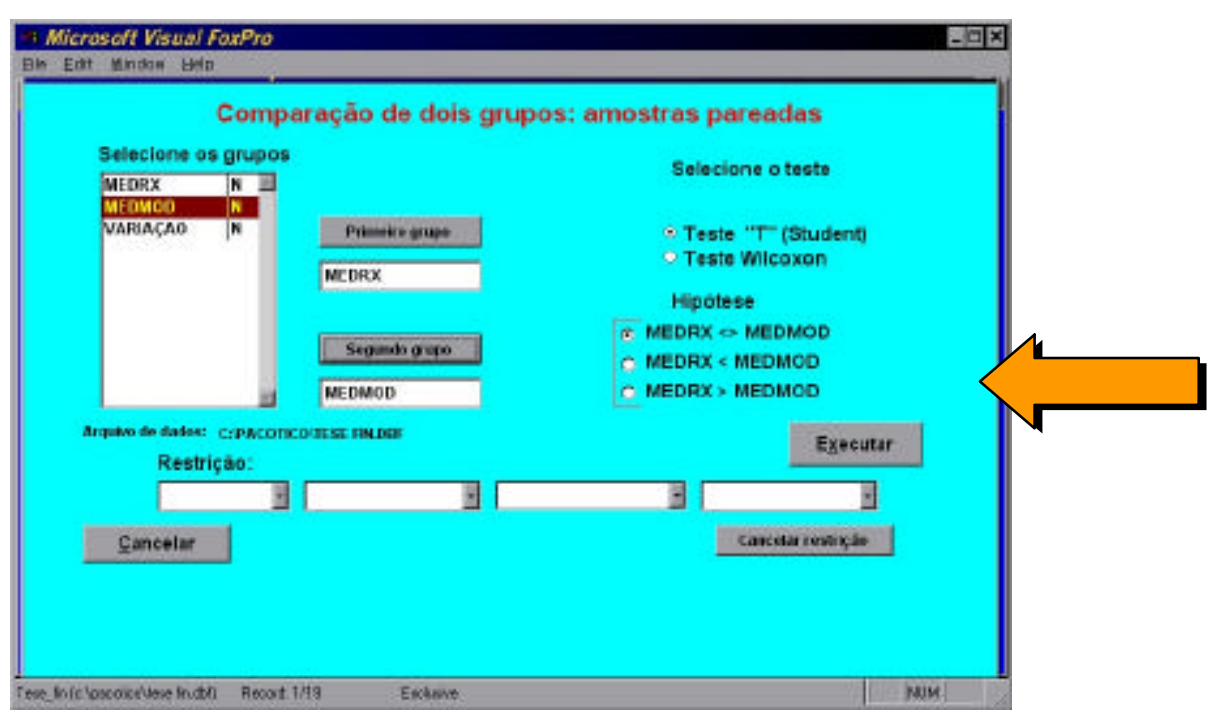

Figura 5.7 - Tela do programa PACOTICO. Seleção dos grupos a serem analisados e hipótese adotada destacada pela seta.

Foi encontrado um valor de $\mathrm{p}<0,05$ nos dois testes, mostrando

a significância da hipótese e permitindo assumir que a medida das radiografias é diferente das medidas dos modelos de gesso (Tabela 5.5 e

Figura 5.8).

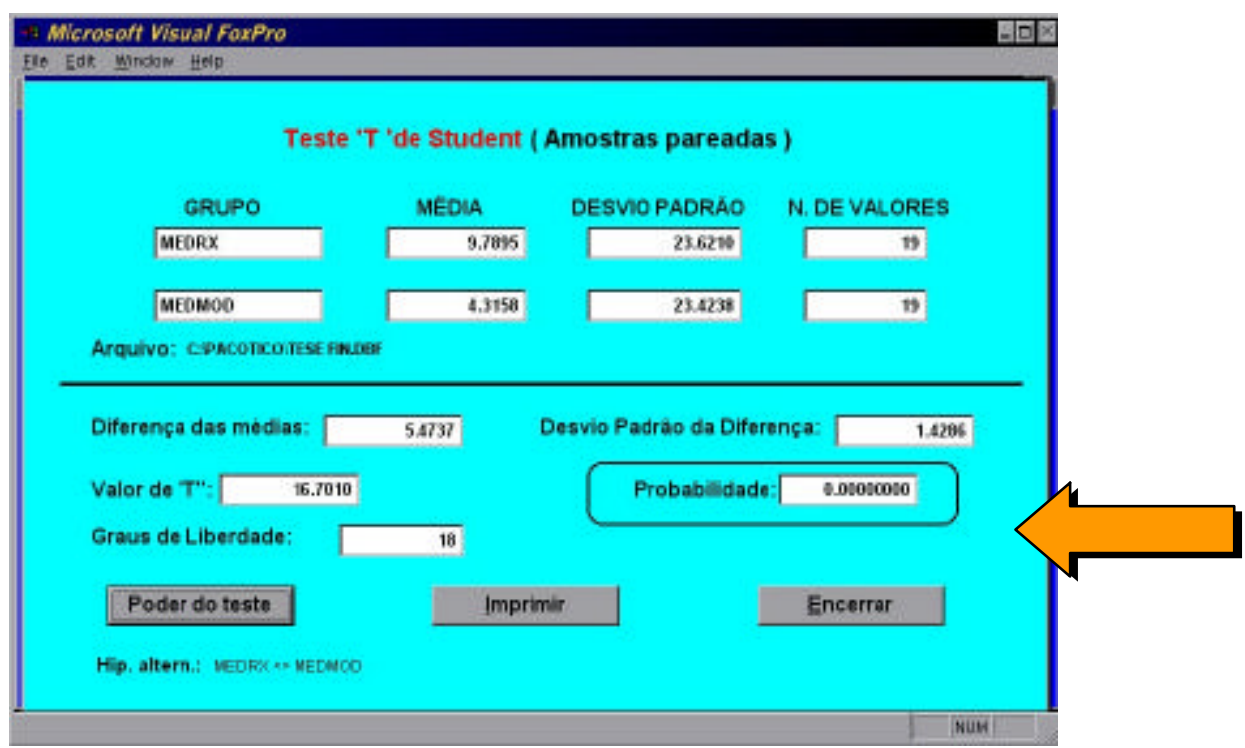

Figura 5.8 - Tela do programa PACOTICO. Resultado obtido para o teste "T" de Student, onde a probabilidade $(\mathrm{p})<0,05$, que é estatisticamente significante. 
$O$ teste " $T$ " de Student mostra que existe uma diferença significante entre os dois grupos estudados, mas não mostra a correlação entre os resultados.

Para se estabelecer a possibilidade de relação entre estes grupos, foi utilizado o teste de correlação de Pearson, onde obtivemos os seguintes resultados (Figura 5.9):

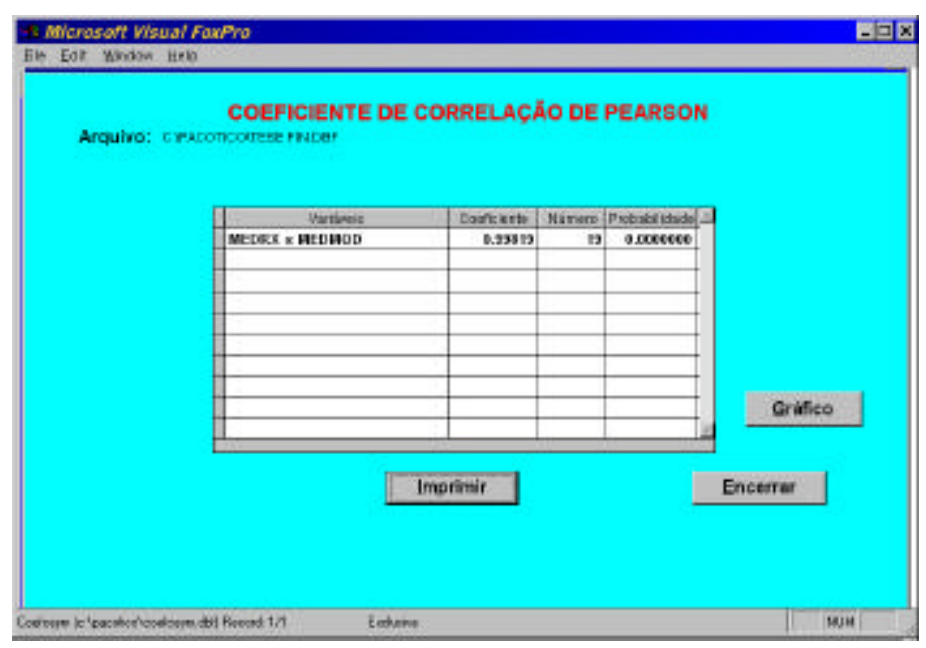

Figura 5.9 - Tela do programa PACOTICO. Aplicação do Coeficiente de Correlação de Pearson.

Estes resultados mostram que existe uma correlação na quantidade de variação dos ângulos entre a radiografia panorâmica e os modelos de gesso do mesmo paciente. 


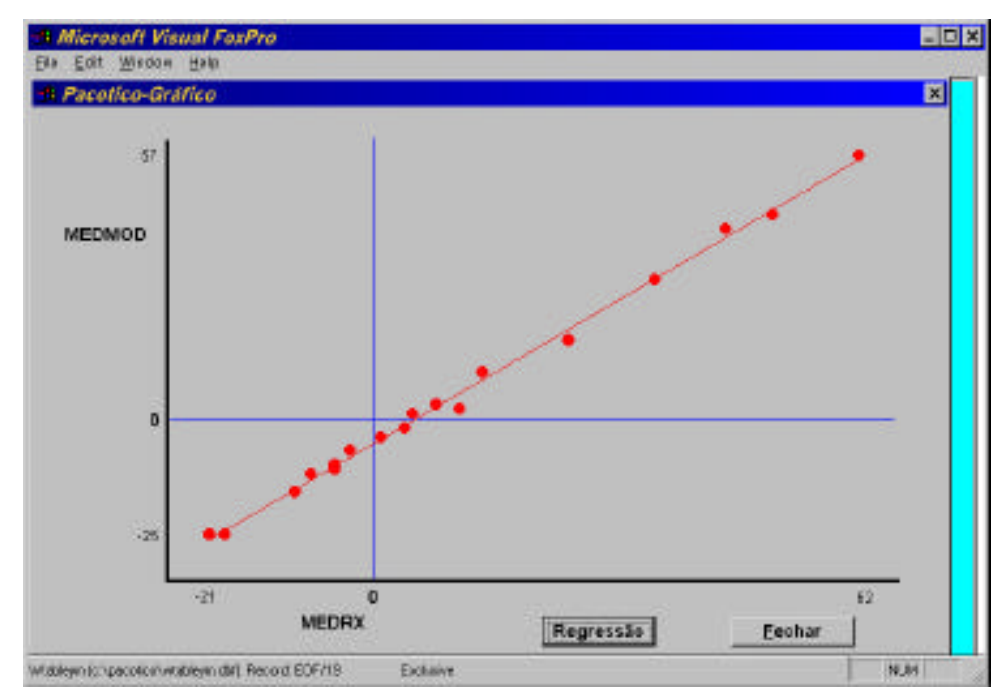

Figura 5.10 - Tela do programa PACOTICO. Gráfico correspondente ao Coeficiente de Correlação de Pearson, mostrando a relação entre os valores obtidos nas radiografias panorâmicas e dos modelos de gesso.

Estes resultados podem ser interpretados da seguinte maneira: a distorção radiográfica produzida pela radiografia panorâmica altera a posição dos terceiros molares inferiores (Figura 5.10). 
6 - DISCUSSÃO 


\section{6 - DISCUSSÃO}

O uso da radiografia panorâmica como um dos principais exames complementares para a maioria das especialidades odontológicas, e principalmente, para o planejamento cirúrgico dos dentes não irrompidos, despertaram nosso interesse no estudo dos efeitos das distorções da imagem radiográfica destes dentes.

Por ser uma técnica radiográfica rotacional, onde o filme e o feixe de raios $\mathrm{X}$ desenvolvem um movimento sincronizado ao redor da cabeça do paciente, fenômenos indesejados, como a distorção, podem ocorrer, sendo esta desvantagem associada à própria técnica radiográfica.

Vários são os fatores que contribuem para a distorção na imagem da radiografia panorâmica, tais como o movimento, a incidência dos raios $\mathrm{X}$ em relação à arcada dentária e o posicionamento do paciente, entre outros $^{8}$. 
Neste trabalho, as distorções angulares foram estudadas, pois a inclinação do terceiro molar em relação ao segundo molar adjacente é um fator importantíssimo no planejamento da exodontia destes.

A inclinação do terceiro molar e sua proximidade com o segundo molar são alguns dos fatores que indicam a necessidade ou não do seccionamento dentário, o que implica em cirurgias mais traumatizantes e longas para o paciente, exigindo uma técnica cirúrgica mais aprimorada e experiência do cirurgião.

Os resultados desta pesquisa nos permitem afirmar que existe uma alteração média de aproximadamente cinco graus, quando comparados os valores encontrados a partir das medidas feitas na radiografia panorâmica com os encontrados nos modelos de gesso obtidos das moldagens trans-cirúrgicas. Com estes resultados, podemos ainda afirmar que existe uma uniformidade nas variações, mostrando que a radiografia panorâmica tende a mesializar os terceiros molares.

Partindo-se destes resultados, empre que observarmos um terceiro molar não irrompido, em uma radiografia panorâmica, para se planejar uma cirurgia, devemos considerar que o dente estará mais distalizado na boca do paciente. Este fato é determinante para que o cirurgião esteja 
preparado para eventuais mudanças do seu planejamento cirúrgico inicial, durante o ato cirúrgico.

\section{1-Prevalência da posição dos terceiros molares}

Com relação à prevalência da posição dos terceiros molares em radiografias panorâmicas em nosso trabalho, obtivemos resultados semelhantes aos trabalhos de PINZAN ${ }^{52}$, OLIVEIRA ${ }^{46}$, DEBONI; GREGORI $^{19}$, onde existe maior prevalência dos terceiros molares mesioangulados seguido pelos verticais.

Porém, quando analisados os modelos de gesso, que mostravam a posição real do dente, houve uma prevalência maior dos dentes distoangulados, seguidos pelos verticais, contrariando os resultados da literatura sobre prevalência da posição dos terceiros molares $19,46,52$. Acreditamos que estes achados são decorrentes da classificação de dentes como verticais nas radiografias panorâmicas, quando na realidade são distoangulados. Após a análise dos resultados de nosso estudo, este fato é explicado pela mesialização do terceiro molar na radiografia panorâmica.

CHANDLER; LASKIN ${ }^{15}$, observando a precisão da radiografia panorâmica na avaliação da posição dos terceiros molares, 
encontraram uma margem de erro de $50 \%$ na classificação destes dentes por cirurgiões-dentistas.

Este é um fator importante, pois as posições distoangulada e mesioangulada aumentam o risco de fraturas mandibulares após a exodontia dos terceiros molares inferiores não irrompidos (LEE; $\operatorname{DODSON}^{35}, \mathrm{IKUZA}^{32}$ ). A posição distoangulada também favorece a infecção do folículo pericoronário, sendo mais um fator a ser considerado para o planejamento cirúrgico e de risco para alveolites pós-operatórias (LEONE; EDENFIELD; $\mathrm{COHEN}^{36}, \mathrm{SWERIN}^{68}$ ).

Outro fator importante, quanto à correta classificação do dente, é o de que dentes distoangulados normalmente apresentam maior probabilidade de complicações na extração, pois seu vetor de saída do alvéolo está praticamente bloqueado pelo ramo ascendente da mandíbula. $\mathrm{O}$ cirurgiãodentista pode necessitar de um retalho mais amplo, uma ostectomia maior e provavelmente do seccionamento dentário, passos estes muitas vezes desnecessários para a exodontia de um dente classificado como vertical. 


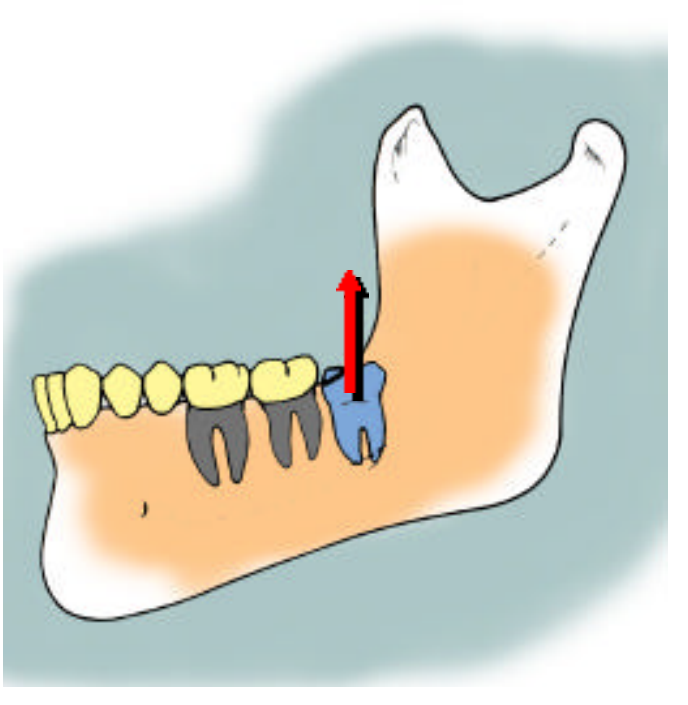

A

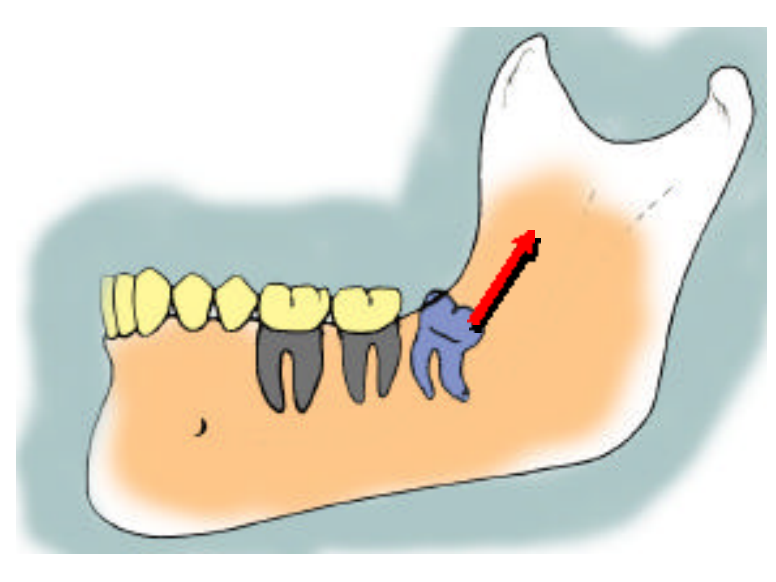

B

Figura 6.1 - Posição Vertical segundo a classifcação de WINTER (A). Posição distoangulada segundo a classificação de WINTER (B). As setas evidenciam o vetor de saída do alvéolo das duas posições.

Nossos achados estão de acordo com $\mathrm{AMIR}^{6}$, que mostra que há um aumento dos valores angulares nas radiografias panorâmicas.

\section{$\underline{6.2 \text { - Variações de classificação e implicações clínicas }}$}

Após a obtenção dos resultados em nosso estudo, preocupamo-nos com a resposta à seguinte pergunta: As distorções por nós constatadas seriam relevantes clinicamente?

Primeiro, devem-se considerar algumas medidas reais do terceiro molar inferior:

A distância mésio distal é em média $10 \mathrm{~mm}^{21}$. 


\section{A altura da coroa é de $7 \mathrm{~mm}^{21}$.}

Calcula-se a distância do ponto médio da junção amelo-cementária até a ponta da cúspide mesial, obtendo-se um valor de 7,43mm (Figura 6.2).

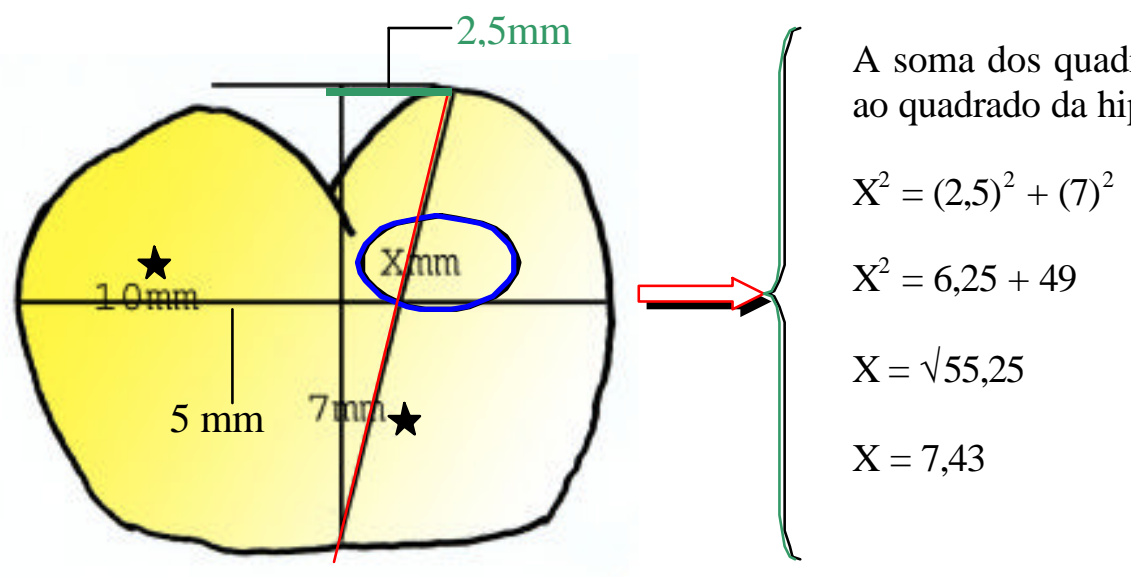

* Valores extraídos de Sicher e DuBrul - Anatomia Oral, 8. ed, 1991, p.163 ${ }^{21}$.

Figura 6.2 - Obtenção do valor do ponto médio da junção amelo-cementária até a cúspide mesial.

Considerando que obtivemos uma variação média de $5,37^{\circ}$ para mesial, chegamos a uma relação matemática simples, onde se levou em consideração que as medidas e tamanhos das estruturas são clínicas.

Para calcularmos a quantidade de deslocamento causado pela distorção radiográfica, é necessário estabelecer que este será sempre para distal quando tomarmos a radiografia panorâmica como referência.

Ao tomarmos um ponto na radiografia panorâmica (a cúspide mesial), o mesmo estará deslocado para a distal clinicamente, 
formando um triângulo com o cateto adjacente, medindo 7,43mm e um ângulo de $5,37^{\circ}$. O cateto oposto ao ângulo determinado por este triângulo é o deslocamento linear do terceiro molar (Figura 6.3).

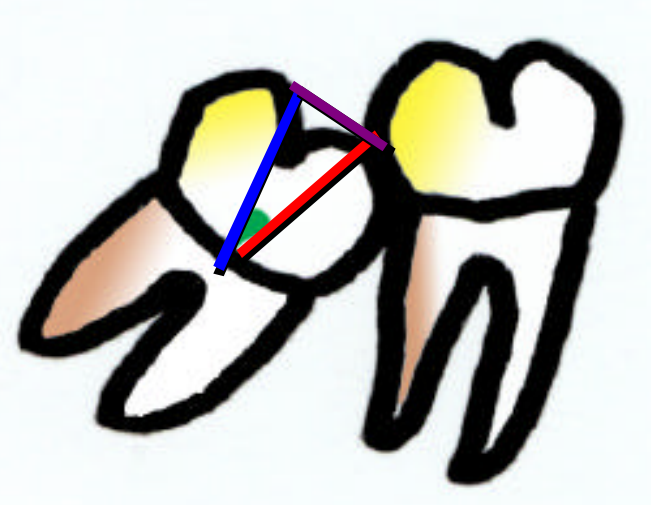

Distância do ponto $\mathrm{M}$ à
cúspide correspondente à
radiografia panorâmica.
Variação angular média da
radiografia panorâmica.
Alteração em mm do
deslocamento dentário devido à
distorção radiográfica.
Distância do ponto M à
cúspide no paciente $(7,43 \mathrm{~mm})$.

Figura 6.3- Variação de posição do terceiro molar clinicamente devido à distorção radiográfica.

Se, em um triângulo reto, temos o cateto adjacente, que é a distância do ponto central da cervical da coroa do terceiro molar até a cúspide mesial e mede 7,43 (Figura 6.2), se sabemos o ângulo, que é de 5,37º, e queremos calcular o cateto oposto, usamos a seguinte fórmula:

$$
\begin{gathered}
\operatorname{tg} \theta^{\circ}=\frac{\text { cateto oposto }}{\text { cateto adjacente }} \Rightarrow \operatorname{tg} 5,37^{\circ}=\frac{X}{7,43} \Rightarrow X=0,094 \times 7,43 \\
X=0,70 \mathrm{~mm}
\end{gathered}
$$


O seccionamento dentário preconizado nas disciplinas de

Cirurgia é feito com o uso de pontas diamantadas $n .^{\circ} 4138$ KG Sorensen ${ }^{\circ}$, pois, após o seccionamento, o espaço referente à sua espessura é suficiente para a remoção da coroa ou de parte dela (Figura 6.4).

Portanto, se tomarmos como referência a posição do terceiro molar inferior na radiografia panorâmica, podemos considerar que este dente está deslocado $0,70 \mathrm{~mm}$ para a distal. Aparentemente o deslocamento devido à distorção radiográfica é pequeno, entretanto, se considerarmos que a ponta diamantada usada para o seccionamento do terceiro molar possui 1,15 mm de espessura, percebe-se a magnitude deste deslocamento e o quanto ele é significativo no planejamento cirúrgico dos terceiros molares inferiores.
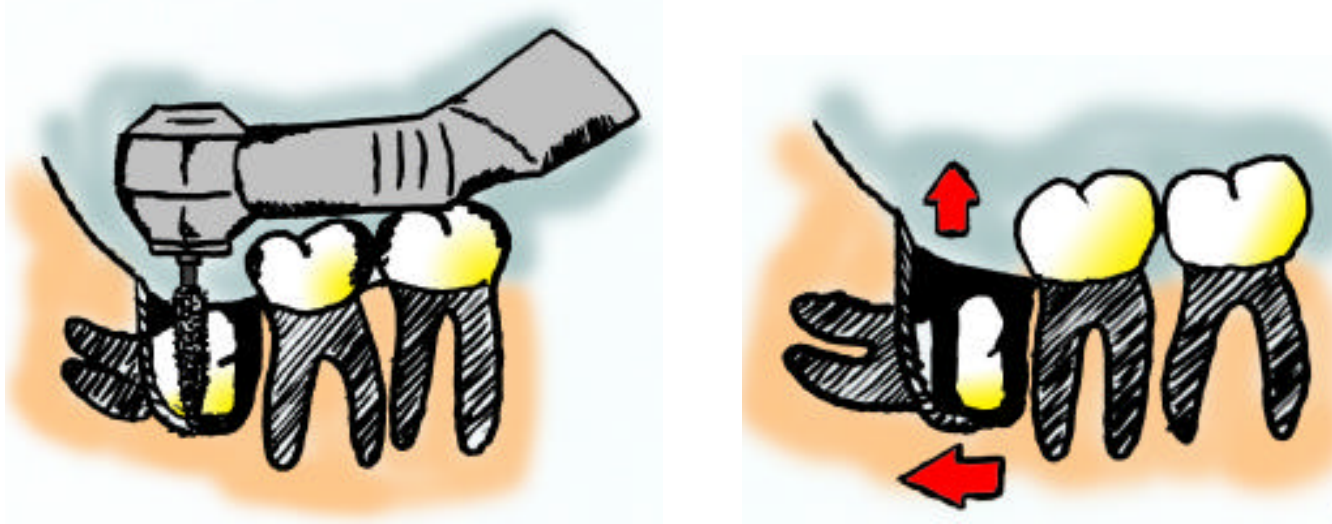

Figura 6.4 - Figura esquemática de odontosecção, evidenciando o espaço da espessura da ponta diamantada para a remoção da coroa do terceiro molar. 
Se mantivermos os mesmos cálculos para a maior variação encontrada no trabalho, que foi de $9^{\circ}$, o deslocamento dentário é de aproximadamente $1,2 \mathrm{~mm}$, que é equivalente à espessura da ponta diamantada utilizada no seccionamento dos dentes. Assim, praticamente todo o ganho da secção dentária estava dentro da margem de erro na interpretação da radiografia panorâmica.

Clinicamente esta distorção pode ser observada de maneiras distintas, conforme a classificação do dente.

Para os dentes classificados a partir da interpretação das radiografias panorâmicas, como horizontais e mesioangulados, esta alteração da posição do terceiro molar não altera o planejamento cirúrgico, e a odontosecção será indicada como forma de conveniência cirúrgica.

Acreditamos que estas alterações sejam mais relevantes nos casos de dentes classificados nas radiografias panorâmicas como discretamente mesioangulados, (tendendo a uma posição mais verticalizada), aos dentes verticais e aos dentes distoangulados.

Nos dentes discretamente mesioangulados, onde poderia haver um planejamento cirúrgico que indicasse a odontosecção, em função da distorção da radiografia panorâmica, poderia resultar em uma cirurgia sem a 
necessidade da odontosecção. Nos dentes classificados radiograficamente como verticais, este mesmo deslocamento pode levar a uma posição mais distoangulada, podendo ser necessária a odontosecção. Nos casos de dentes distoangulados, devemos considerar que o dente estará mais afastado do segundo molar do que aparenta a imagem na radiografia panorâmica, resultando, em alguns casos, em uma técnica cirúrgica mais agressiva aos tecidos do que planejado através da interpretação radiográfica.

Ressaltamos que a indicação do seccionamento dentário é feita quando a impacção do terceiro molar é decorrente do posicionamento dos dentes, ou seja, o equador protético do terceiro molar está abaixo do equador protético do segundo molar. Nos casos de raízes divergentes o seccionamento dentário sempre será indicado com finalidade de separação das raízes.

Clinicamente, existe ainda o espaço deixado pela espessura da broca de ostectomia, que pode facilitar a exodontia destes terceiros molares sem o auxílio da odontosecção. Fato este que também ajuda a explicar as observações diárias em que muitos casos indique-se a odontosecção na radiografia panorâmica e não a utilize na cirurgia.

Os resultados obtidos neste trabalho reforçam os achados de autores que avaliaram distorções angulares, onde a variação média em 
radiografias panorâmicas, foi de 5 a $6^{\circ 6,}, 34,58,77$. mostrando que, no planejamento cirúrgico de um terceiro molar inferior, esta distorção não pode ser desprezada.

Outro fator relevante foi destacado por HAAVIKKO, ALTONEN e MATTILA ${ }^{27}$, em 1978, que comprovaram a importância da correta avaliação da angulação dos terceiros molares, pois é um dos indicadores do irrompimento ou não destes dentes, contra-indicando sua remoção.

Baseados nos resultados obtidos, podemos considerar que a distorção angular na região posterior da mandíbula é de grande importância no planejamento da exodontia dos terceiros molares inferiores.

\section{3- Distorção radiográfica}

Após a avaliação das radiografias panorâmicas, encontramos sempre mesialização dos terceiros molares. Acreditamos que a explicação mais lógica esteja relacionada aos fatores de produção da imagem na radiografia panorâmica. Alguns autores ${ }^{34,68,74}$ afirmam que a distorção angular é a combinação dos fatores de distorção radiográfica vertical e horizontal. 
As radiografias obtidas neste estudo foram realizadas por apenas um operador experiente, e no mesmo aparelho, o que com certeza minimizou alterações decorrentes da técnica radiográfica.

Outro fator considerado foi o de que, em estudos longitudinais de controle radiográfico de terceiros molares inferiores, há alteração radiográfica da posição dos mesmos ao longo dos anos (KAHL; GERLACH; HILGERS ${ }^{33}$, em1994, BROCKBANK ${ }^{10}$, em 1981 TAIT $^{66}$, em 1984 GARCIA; CHAUNCEY ${ }^{24}$, em 1989 VON WOWERN; NIELSEN ${ }^{73}$, em 1989 RICHARDSON ${ }^{56}$, em 1992, HATTAB $^{28}$, em 1997, VENTÄ; TURTOLA; YLIPAAVALNIEMI $^{72}$, em 1999). Em função da alteração de posição dos dentes, os pacientes foram submetidos à cirurgia em até 1 mês depois da realização das radiografias panorâmicas, por acreditarmos que o dente não sofreria movimentação neste período. Portanto, caso constatássemos alguma alteração na posição do terceiro molar, esta seria devida à distorção da radiografia panorâmica e não à movimentação dentária.

Estes dados reforçam a importância dos exames radiográficos recentes no planejamento das exodontias de terceiros molares, porque assim o cirurgião-dentista deverá se preocupar apenas com as distorções inerentes à formação da imagem radiográfica. Quando o espaço de tempo entre a realização da radiografia panorâmica e a cirurgia é grande, além das 


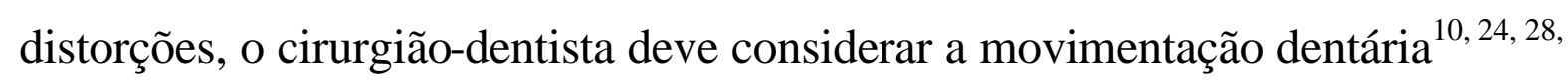
$29,56,62,64,65,72,73$

O aparelho Rotograph® foi escolhido para este trabalho, pois é o aparelho disponível na Faculdade de Odontologia de Bauru que possui menor distorção radiográfica ${ }^{8}$.

Este fato leva a outra consideração: o cirurgião-dentista deve estar familiarizado com o aparelho panorâmico com que trabalha, a fim de conhecer as distorções inerentes a este aparelho. Acreditamos que, em outros aparelhos, as distorções angulares possam variar, visto que as distorções verticais e horizontais também variam entre os aparelhos ${ }^{8}$.

Concordamos com WELANDER ${ }^{74}$, quando afirma que a radiografia panorâmica é uma imagem bidimensional, e que, para a correta aferição da inclinação e posição de algum objeto, pelo menos mais uma projeção radiográfica deve ser feita (uma radiografia oclusal). Mas a radiografia panorâmica ainda nos proporciona uma qualidade de imagem confiável, desde que saibamos suas limitações, discordando de CHANDLER; LASKIN $^{15}$, que afirmam que a radiografia panorâmica não é um recurso confiável no planejamento das exodontias de terceiros molares não irrompidos. 
7 - CONCLUSÕES 


\section{7 - CONCLUSÕES}

Após a análise dos resultados obtidos neste trabalho podemos concluir que:

Foi observada uma variação média entre medidas angulares da radiografia panorâmica e do modelo de gesso de 5,37 .

+ A maior variação encontrada foi de $9^{\circ}$.

* O deslocamento dentário, devido à distorção angular da radiografia panorâmica é, em média, de 0,741 mm, podendo atingir 1,2 mm, valores de importância clínica.

A radiografia panorâmica é um método de exame válido para o diagnóstico e planejamento cirúrgico dos terceiros molares, desde que o cirurgião-dentista esteja familiarizado com suas limitações e características. 
ANEXOS 


\section{FACULDADE DE ODONTOLOGIA DE BAURU}

COMITÊ de ÉTICA EM PEsQUiSA

Bauru, 30 de março de 2001

Ilma. Sra.

Profa. Dra. Ana Lúcia Alvares Capelozza

FOB USP

Senhora Professora.

O projeto de pesquisa denominado "Avaliação da distorção da imagem radiográfiea na região de terceiros molares inferiores em radiografias panorâmieas - implicações elinieas no trans-eirúrgico e pósperatório" de autoria C.D. Luiz Fernando de Mello Sant'ana e que será desenvolvido sob sua orientaçao, foi recebido por este Comitê e encaminhado ao relator para avaliação quanto aos seus aspectos éticos.

O parecer do relator, aprovando o projeto, foi aceito pelo Comitê de Ética em Pesquisa desta Faculdade na reuniao do dia 29 de março de 2001.

Atenciosamente

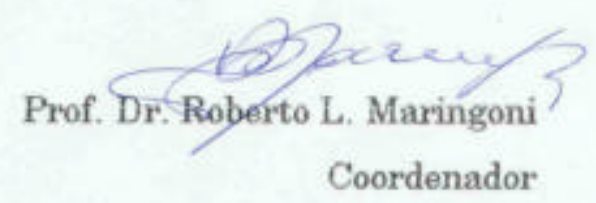

Anexo 1 - Parecer favorável do Comitê de Ética em Pesquisa da Faculdade de Odontologia de Bauru. 


UNIVERSWADEDESAO PAULO
FACULDADEDE ODONTOLOGIA DE BAURU
CLINICA DE CIRURGIA

\begin{tabular}{|c|c|c|c|}
\hline NOME: & & \multirow{2}{*}{ EST.CTVI: } & \multirow{2}{*}{$\begin{array}{l}\text { IDADE: } \\
\text { UF: }\end{array}$} \\
\hline DATA DE NASCIMI & LOCAL DE NASC: & & \\
\hline NACIONALIDADE & SEXO: & PESO: & ALTURA: \\
\hline OCUPACূAO: & PROCEDÊNCIA: & ZONA URBANA（） & ZONA RURAL ( ) \\
\hline \multicolumn{2}{|l|}{ ENDEREÇO;: } & $\mathbf{N}^{\mathbf{0}}$ & \\
\hline CIDADE: & UF: FONE ( & 1 & \\
\hline
\end{tabular}

\section{AUTORRACLAO PARA DIAGNÓSTICO E OUEXECUCAAO DE TRATAMENTO}

Por este instrumento de autorização por mim assinada, dou pleno consentimento à FACULDADE DE ODONIOLOGLA DE BAURU-USP para por intermédio de seus professores, assistentes $e$ ahmos devidamente autorizados, faser diagnóstico, planejamento e tratamento em minha pessoa de acordo com os conhecimentos enquadrados no campo dessa especialidade.

Concordo também, que todas as radiografias, fotografias, modelos, desenhos, históricos de antecedentes familiares, resultados de exame clínico e de laboratório e quaisquer outras informaçöes concernentes ao planejamento, diagnóstico e/ou tratamento, constituem propriedade exclusiva desta FACULDADE a qual dou plenos direitos de retenção, uso para quaisquer fins de ensino $e$ de divulgação em jomais e/ou em revistas cientfficas do pais $e$ do estrangeiro, respeitando os respectivos códigos de ética.

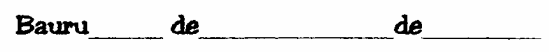

Assinatura do paciente ou responsável

QUECXA PRIVCPPAL.

HISTORRIA DA DOENCSA ATUAL

HISTORIA MEDICA.

Ol. Já teve hemorragia ?

O2. Sofre (u) de alengia?

O3. Teve reumatismo infeccioso?

04. Sofre (u) de distúrbio cardiovascular?

O5. Sofre (u) de gastrite ou úlcera?

06. É diabético ou tem familiares diabéticos

O7. Já desmaiou algưna ves?

O8. Está sob tratamento médico?

O9. Está tomando algum medicamento?

10. Esteve doente ou foi operado nos últimos 5 anos?

11. Tem hábitos, vicios ou manias?

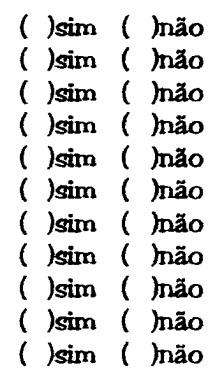

Anexo 2.1 - Ficha de exame do paciente utilizada nas Disciplinas de Cirurgia da Faculdade de Odontologia de Bauru - USP 


\section{EXAME FISICO.}

- Geral

- Loco-regional _.

- Glandulas salivares

- Linfonodos

- ATM

- Músculos mastigadores

Local
O1. Lábios
O2. Mucosa jugal
O3. Língua
O4. Soalho de boca
O5. Palato duro
O6. Palato mole
O7. Garganta
O8. Mucosa alveolar
O9. Gengivas
10. Oclusăo

N A

( ) ( )

( ) ( )

( ) ( )

( ) ( )

( ) ( )

( ) ( )

( ) ( )

( ) ( )

( ) ( )

10. Oclusão

( ) ( )

SINAIS VTTALS

Pressão Arterial: Sistólica:

Diastólica:

Pulso:

Respiraçäo:

Temperatura:

Anexo 2.2 - Ficha de exame do paciente utilizada nas Disciplinas de Cirurgia da

Faculdade de Odontologia de Bauru - USP 


\section{Carta de Informação ao Paciente}

Eu,

portador(a) da cédula de identidade $n^{\circ}$ estou através

desta tomando conhecimento dos procedimentos envolvidos na pesquisa conduzida pelo C.D. Luís Fernando de Mello Sant' Ana, portador do RG $n .^{\circ}$ 27708312-6 e devidamente inscrito no CROSP sob o $n^{\circ} 59.988$ e atualmente cursando a pós-graduação em nível de mestrado em Estomatologia, na Faculdade de Odontologia de Bauru, USP; sob a orientação da Prof. ${ }^{a}$ Dr. ${ }^{a}$ Ana Lúcia Alvares Capelozza, professora doutora deste departamento.

A pesquisa em questão visa avaliar a distorção radiográfica na região de terceiros molares inferiores não irrompidos ou parcialmente irrompidos. Estou ciente de que serie submetido a cirurgia bucal, indicada após exame clínico e complementar.

Durante a cirurgia, que visa exclusivamente o tratamento de patologias, restabelecimento de função e tratamento profilático de doenças associadas aos terceiros molares, será realizada uma moldagem, sendo este 0 único passo que foge d̀ técnica convencional para exodontia dos terceiros molares.

Declaro, que de livre e espontânea vontade, os dentes extraídos farão parte de um banco de dentes em estoque que poderão ou não ser usados em outras pesquisas da FOB-USP.

Declaro estar ciente dos riscos inerentes a cirurgia, bem como serem verdadeiras as informações prestadas por mim no exame clínico.

Tomando como verdade o escrito acima, autorizo o C.D. Luís Fernando de Mello Sant'Ana a realizar os procedimentos cirúrgicos necessários para o meu tratamento, bem como utilizar os dados colhidos durante o ato cirúrgico em sua pesquisa.

Bauru, de de 2001.

Assinatura do paciente

C.D. Luís Fernando de Mello Sant' Ana Aluno de pós-graduação em Estomatologia

Anexo 3 - Carta de informação ao paciente. 


\section{UNIVERSIDADE DE SÃO PAULO \\ FACULDADE DE ODONTOLOGIA DE BAURU COMITE DE ÉTICA EM PESQUISA TERMO DE CONSENTIMENTO LIVRE E ESCLARECIDO}

Pelo presente instrumento que atende às exigências legais, o senhor(a) portador(a) da cédula de

identidade $n{ }^{\circ}$ após leitura minuciosa da CARTA DE INFORMAČ̃̃O AO PACIENTE, devidamente explicada pelos profissionais em seus mínimos detalhes, ciente dos serviços e procedimentos aos quais será submetido, nâo restando qualquer dúvida a respeito do lido e explicado, firma se CONSENTIMENTO LIVRE E ESCLARECIDO em concordância em participar na pesquisa proposta no que the é cabível, conforme a CARTA DE INFORMAÇÃO AO PACIENTE.

Fica claro que o paciente ou seu representante legal, podem a qualquer momento retirar seu CONSENTIMENTO LIVRE E ESCLARECIDO e deixar de participar do estudo alvo da pesquisa e ciente de que todo o trabalho realizado torna-se informação confidencial guardada por força de sigilo profissional (Art. 9. do código de Ética Odontológica).

Por estarem entendidos e conformados, assinam o presente termo.

Baun, de de 2001.

Assinatura do paciente

C.D. Luís Fernando de Mello Sant Ana Aluno de pós-graduação em Estomatologia

Anexo 4 - Termo de consentimento livre e esclarecido 
Ficha de Comparação de Valores de Angulações dos

Terceiros Molares nas Radiografias Panorâmicas e

Modelo de Gesso

\begin{tabular}{|l|}
\hline Paciente: \\
\hline Datada Radiografia: \\
\hline
\end{tabular}

\begin{tabular}{|l|}
\hline LADO ESQUERDO: \\
\hline Medida em "na radiografia: \\
\hline Medida em " no modeb: \\
\hline Variaçăo: \\
\hline Datada cinurga: \\
\hline
\end{tabular}

\begin{tabular}{|l|}
\hline LADO DIREITO: \\
\hline Medida em "na radiografia: \\
\hline Medida em " no modeb: \\
\hline Variaçăo: \\
\hline Data da cinurga: \\
\hline
\end{tabular}

Anexo 5 - Ficha elaborada para a pesquisa com a finalidade de anotação dos valores encontrados nas radiografias panorâmicas e nos modelos de gesso. 


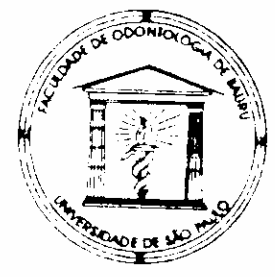

\section{UNIVERSIDADE DE SÃO PAULO \\ FACULDADE DE ODONTOLOGIA DE BAURU DEPARTAMENTO DE ESTOMATOLOGIA CIRURGIA}

\section{Instrucóes para os pacientes operados na boca}

1. Retirar a gaze da boca após uma hora.

2. Aplicar bolsas de gelo na face, sobre o local operado até as ....

3. Náo fazer bochechos no dia de hoje, somente lavar a boca, principalmente aposs as refeiçð̃es, com solução fria de água e sal.

4. Tomar

durante dias.

5. Em caso de saída de sangue maior do que o normal, comprimir o local com um rolo de gaze ou de algodão por 10 minutos.

6. Se após ter tomado as providências recomendadas não houver melhora ou houver complicaçð̃es, procure a Faculdade ou telefone para o número (0xx14)235-8258.

7. Hoje, alimentos líquidos, de preferência frios ou gelados (caldos, leite, mingaus. sorvete. suco de frutas, vitaminas e yogurts).

8. Hoje, cvitar os excessos fisicos e mentais, se necessário manter repouso na cama, deite com a cabeça mais elevada do que o resto do corpo.

9. A partir de amanha, higicne da boca com solução morna de água e sal ( 1 colher de chá de sal em $1 / 2$ copo d'água ), alimentação normal e compressas quentes na face se inchar muito.

10. Os dentes podem continuar a serem escovados, só tomando cuidado com o lugar operado, até sarar.

Anexo 6 - Instruções pós-operatórias dadas aos pacientes. 

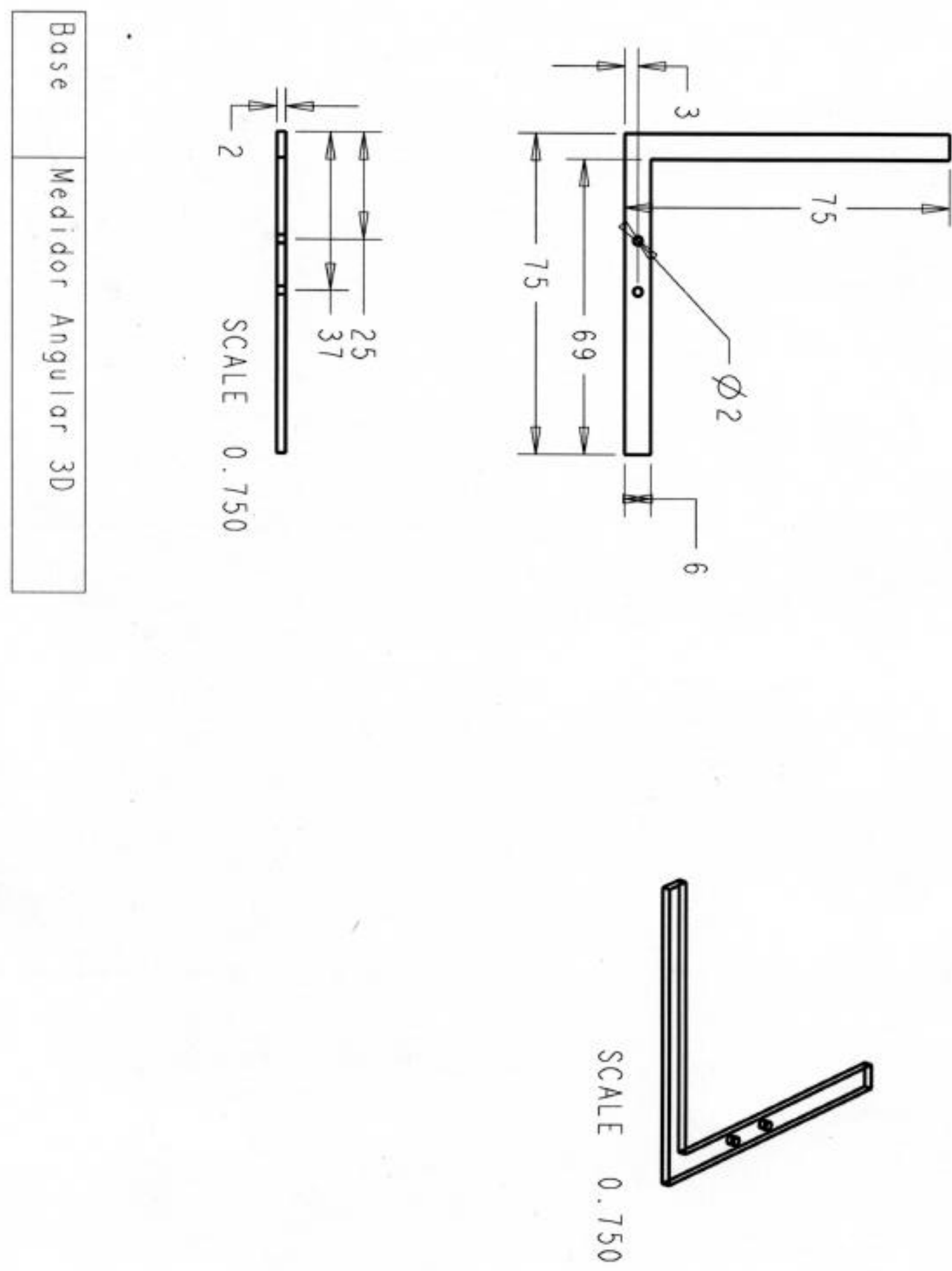

Anexo 7.1 - Desenho esquemático técnico da base "L" do dispositivo para aferição das medidas angulares nos modelos de gesso. 

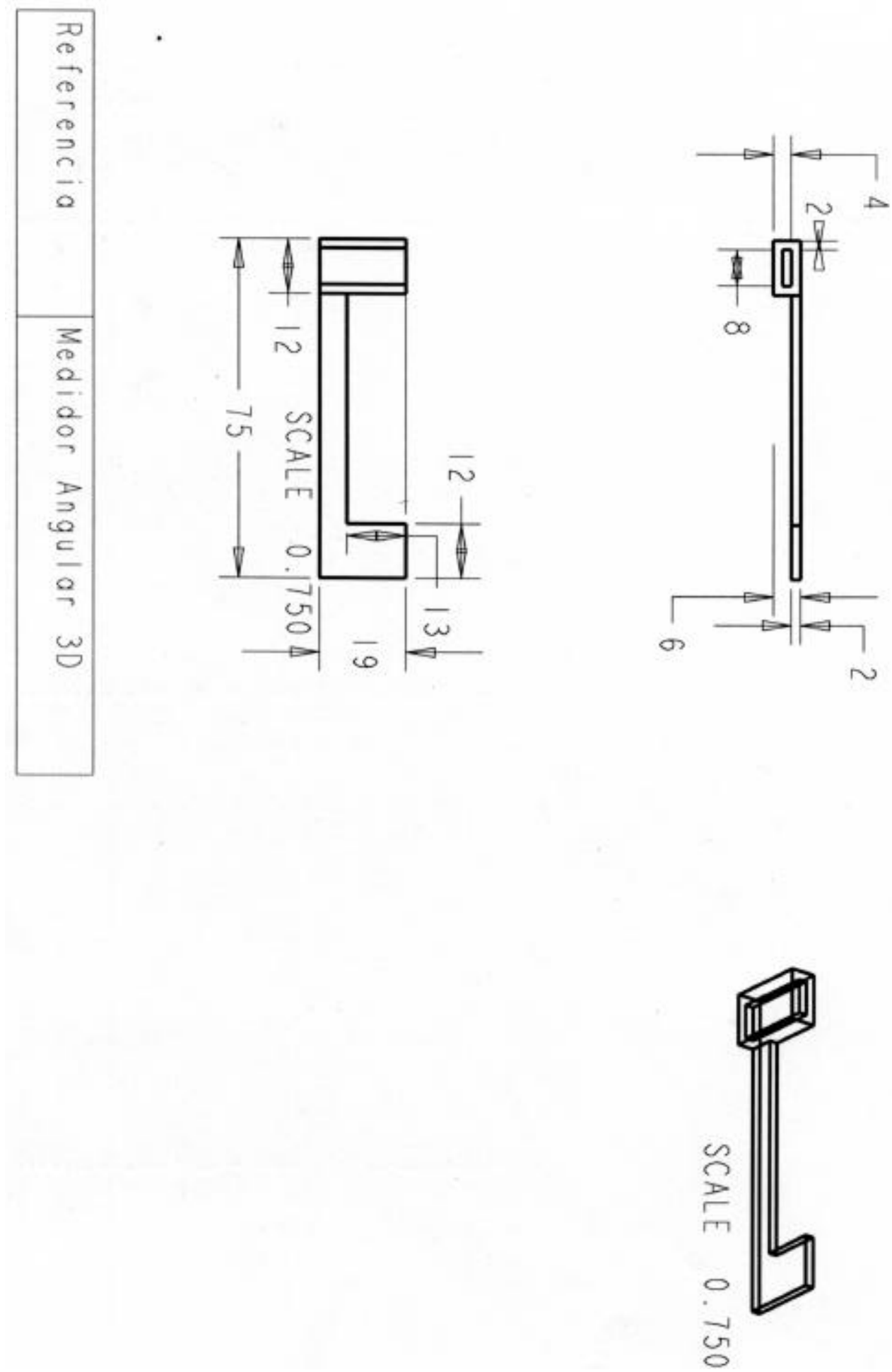

Anexo 7.2 - Desenho esquemático técnico da base vertical do dispositivo para aferição das medidas angulares nos modelos de gesso. 


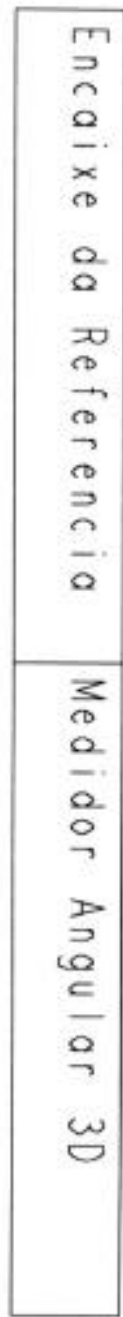
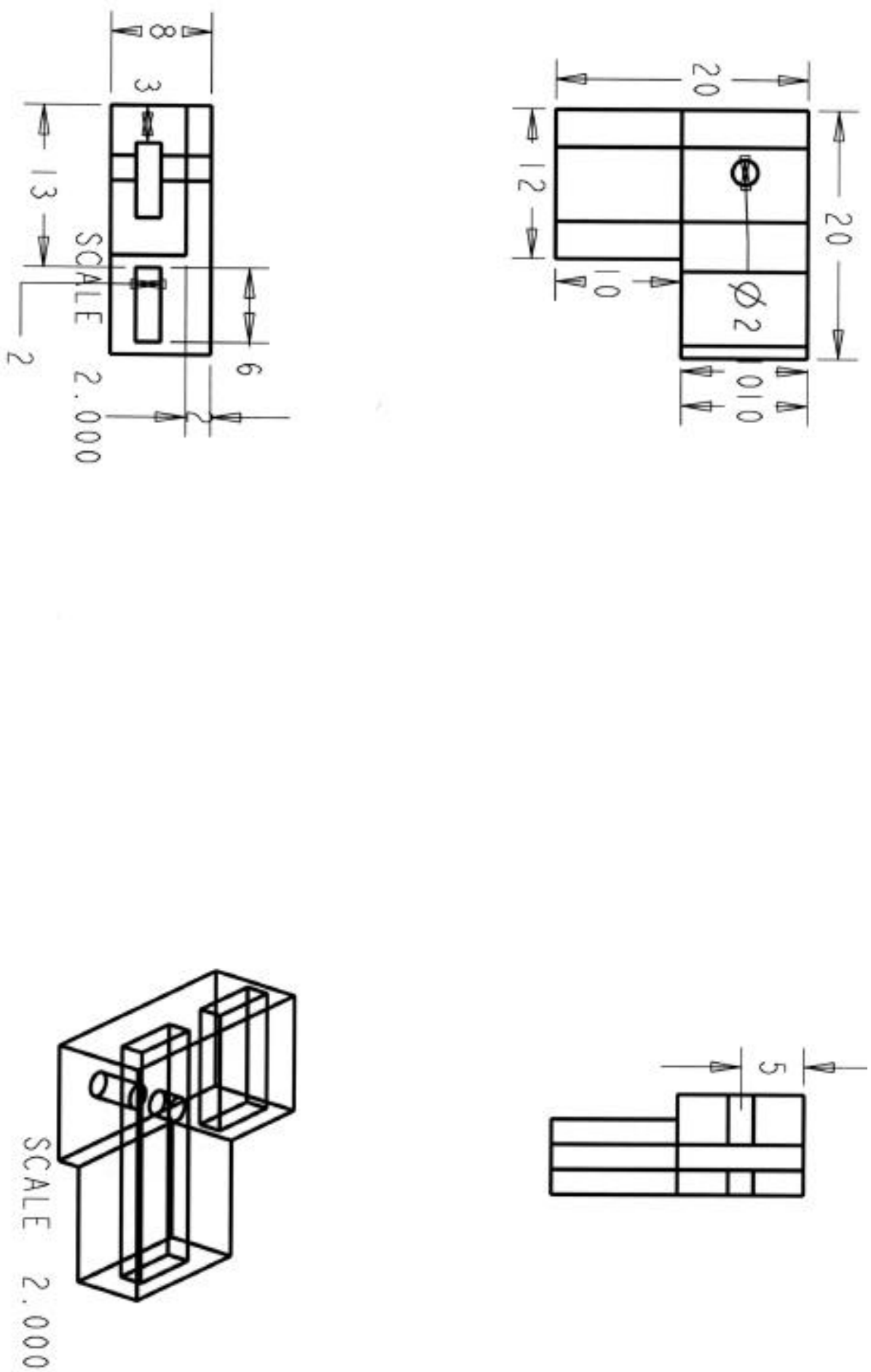

Anexo 7.3 - Desenho esquemático técnico do encaixe do transferidor da base vertical do dispositivo para aferição das medidas angulares nos modelos de gesso. 
REFERÊNCIAS BIBLIOGRÁFICAS 


\section{REFERÊNCIAS BIBLIOGRÁFICAS*1}

1. AITASALO, K.; LEHTINEN, R.; OKSALA, E. An orthopantomographic study of prevalence of impacted teeth. Int $\mathbf{J}$ Oral Surg., v. 1, n. 1, p. 117-20, Jan, 1972.

2. AL-KHATEEB, T.L.; EL-MARSAFI, A.I.; BUTLER, N.P. The relationship between the indications for the surgical removal of impacted third molars and the incidence of alveolar osteitis. J Oral Maxillofac Surg., v. 49, n. 2, p. 141-6, Feb, 1991.

3. ALATTAR, M.M.; BAUGHMAN, R.A.; COLLETT, W.K. A survey of panoramic radiographs for evaluation of normal and pathologic findings. Oral Surg., v. 50, n. 5, p. 472-78, Nov., 1980.

4. ALMEIDA, S.M.; BOSCOLO, F.N.; MONTEBELO F ${ }^{\circ}$, A. Estudo das distorções da imagem radiográfica produzida em aparelhos

\footnotetext{
* Normas recomendadas para o uso no âmbito da Universidade de São Paulo, com base no documento "Referências Bibliográficas", oferecido pelo Serviço de Biblioteca e Documentação da Faculdade de Odontologia de Bauru, de 2001.
} 
panorâmicos que se utilizam os princípios ortopantomográficos e elipsopantomográficos. Rev Odontol Univ São Paulo., v. 9, n. 2, p. 91-99, Abr-Jun, 1995.

5. ALVARES, L.C.; TAVANO, O. Curso de Radiologia em Odontologia. $3^{\mathrm{a}}$. edição, São Paulo, Ed. Santos, 1993, p.94-105.

6. AMIR, C.; et al. Evaluation of the precision of dimensional measurements of the mandible on panoramic radiographs. Oral Surg Oral Med Oral Pathol Oral Radiol Endod., v. 86, n. 2, p. 242-8, Aug, 1998.

7. ARAÚJO, P.A.; et al. Materiais para moldagem à base de borracha (elastômeros). In: Materiais Dentários I - Não

Metálicos. Apostila do departamento de Dentística, Endodontia e Materiais Dentários, da Disciplina de Materiais Dentários, Bauru 1992.

8. ÁVILA, M.A.G. Análise das Distorções da Imagem Radiográfica em Diferentes Aparelhos Panorâmicos. Bauru, 1996. 124p. Dissertação de Mestrado apresentado na Faculdade de Odontologia de Bauru. 
9. AZAZ, B.; SHTEYER, A.; PIAMENTA, M. Radiographic and clinical manifestations of the impacted mandibular third molar. Int $\mathbf{J}$ Oral Surg., v. 5, n. 4, p. 153-60, Aug, 1976.

10. BROCKBANK, J. Change in position of unerupted mandibular third molars. Oral Surg Oral Med Oral Pathol., v. 51, n. 4, p. 461, Apr., 1981.

11. BROOKS, S.L. Guidelines for Radiologic examinations: Do we have all the answers yet? Oral Surg Oral Med Oral Pathol Oral Radiol Endod., v. 83, n. 5, p. 523-4, May, 1997.

12. BRUCE, R.A.; FREDERICKSON, G.C.; SMALL, G.S. Age of patients and morbidity associated with mandibular third molar surgery. J Am Dent Assoc., v. 101, n. 2, p. 240-5, Aug, 1980.

13. CARVAlHO, A.C.P.; CALlESTINI, E.A.; SANCHES, M.G. Transtornos provocados por dentes inclusos - Considerações gerais. Ars Cvrandi Odontol., v. 5, n. 8, p. 34-42, Nov., 1978.

14. CARVALHO, A.C.P.; WASSANO, S.I.; ODIN FILHO, F.A. Dentes inclusos. Ocorrência de extração e de transtornos. RGO., v. 27, n. 4, p. 264-7, Out., 1979. 
15. CHANDLER, L.P.; LASKIN, D.M. Accuracy of radiographs in classification of impacted third molar teeth. J Oral Maxillofac Surg., v. 46, n. 8, p. 656-60, Aug, 1988.

16. COHEN, M.E.; et al. Age-specific angulation of unerupted human third molar teeth in a coss-sectional sample. Arch Oral Biol., v. 30, n. 5, p. 441-4, 1985.

17. COOK, W.D.; THOMASZ, F. Rubber gloves and addition silicone materials. Aust Dent J., v. 31, n. 2, p. 140, Apr., 1986.

18. DACHI, S.F.; HOWELL, F.V. A survey of 3874 routine full-mouth radiographs. Oral Surg Oral Med Oral Pathol., v. 14, n. 10, p. 1165-9, Oct, 1961.

19. DEBONI, M.C.Z.; GREGORI, C. Aferição das posições prevalentes dos terceiros molares inferiores inclusos. Rev Odontol Univ São Paulo., v. 4, n. 2, p. 87-91, Abr., 1990.

20. DEN BRABER, E.T.; RUIJTER, J.E.; JANSEN, J.A. The effect of a subcutaneous silicone rubber implant with shallow surface microgrooves on the surrounding tissues in rabbits. J Biomed Mat Res., v. 37, n. 4, p. 539-47, Dec., 1997.

21. DuBRUL, E.L. Anatomia Oral de Sicher e DuBrul. 8. ed. Ed. Artes Médicas, São Paulo, 1991. 
22. ELIASSON, S.; HEIMDAHL, A; NORDENRAM, Ä. Pathological changes related to long-term impaction of third molars: A radiographic study. Int J Oral Maxillofac Surg., v. 18, n. 4, p. 2102, Aug, 1989.

23. FREITAS, A.; TORRES, F.A. Radiografias panorâmicas. In: FREITAS, A.; ROSA, J.E.; SOUZA, I.C. Radiologia Odontológica, São Paulo, Ed. Artes Médicas, 2.ed., 1988, Cap. 11, p. 209-36.

24. GARCIA, R.I.; CHAUNCEY, H.M. The eruption of third molars in adults: A 10-year longitudinal study. Oral Surg Oral Med Oral Pathol., v.68, n.1, p.9-13, Jul, 1989.

25. GIRDLER, N.M. The unpredictability of impacted third molar development - the danger of passive observation. Br Dent J., v. 168, n. 3, p. 92, Feb, 1990.

26. GURALNICK, W. Third molar surgery. Br Dent J., v. 156, n. 11, p. 389-94, Jun, 1984.

27. HAAVIKKO, K.; ALTONEN, M; MATTILA, K. Predicting angulational development and eruption of the lower third molar. Angle Orthod., v. 48, n. 1, p. 39-48, Jan, 1978. 
28. HATTAB, F.N. Positional changes and eruption of impacted mandibular third molars in young adults: a radiographic 4-year follow-up study. Oral Surg Oral Med Oral Pathol Oral Radiol Endod., v.84, n.6, p. 604-8, dec., 1997.

29. HATTAB, F.N.; ALHAIJA, E.S.J.A. Radiographic evaluation of mandibular third molar eruption space. Oral Surg Oral Med Oral Pathol Oral Radiol Endod., v. 88, n. 3, p. 285-91, Sep, 1999.

30. HAYAKAWA, Y.; et al. Morphometric analysis of image distortion with rotational panoramic radiography. Bull Tokyo Dent Coll., v. 34, n. 2, p. 51-8, May, 1993.

31. HIRSCHMANN, P.N. The current status of panoramic radiography. Int Dent J., v. 37, n. 1, p. 31-7, Mar, 1987.

32. IIZUKA, T.; TANNER, S.; BERTHOLD, H. Mandibular fractures following third molar extraction. A retrospective clinical and radiological study. Int J Oral Maxillofac Surg., v. 26, n. 5, p. 33843, Oct, 1997.

33. KAHL, B.; GERLACH, K.L.; HILGERS, R.D. A long-term, followup, radiographic evaluation of asymptomatic impacted third molars in orthodontically treated patients. Int J Oral Maxillofac Surg., v. 23, n. 5, p. 279-85, Oct, 1994. 
34. LANGLAND, O.E. et al. Panoramic radiology., 2. ed. Philadelphia, Lea \& Febiger, 1989.

35. LEE, J. T.; DODSON, T.B. The effet of mandibular third molar presence and position on the risk of an angle fracture. J Oral Maxillofac Surg., v. 58, n. 4, p. 394-99, Apr, 2000.

36. LEONE, S.A.; EDENFIELD, M.J.; COHEN, M.E. Correlation of acute pericoronitis and the position of the mandibular third molar. Oral Surg Oral Med Oral Pathol., v. 62, n. 3, p. 245-50, Sep, 1986.

37. LUND, T.M.; MANSON-HING, L.R. Relations between tooth positions and focal troughs of panoramic machines. Oral Surg Oral Med Oral Pathol Oral Radiol Endod., v. 40, n. 2, p. 285-93, Aug, 1975.

38. McDAVID, W.D. et al. Definitions of unsharpness and layer thickness in rotational panoramic radiography. Oral Surg Oral Med Oral Pathol., v. 57, n. 1, p. 96-101, Jan, 1984.

39. MALAMED, S.F. Handbook of Local Anesthesia. 4.ed, St. Louis, Mosby, 1999.

40. MARZOLA, C. Retenção Dental. In: Retenção Dental. São Paulo, Ed. Pancast, 2.ed., 1995, Cap. 1, p. 13-49. 
41. MARZOLA, C. Terceiros Molares Inferiores Retidos. In:

Retenção Dental. São Paulo, Ed. Pancast, 2. ed., 1995, Cap. 2, p. 51-116.

42. MARZOLA, C. Anestesiologia. 3. ed.ver.aum, São Paulo, Pancast, 1999.

43. MORRIS, C.R.; JERMAN, A.C. Panoramic radiographic survey: a study of embedded third molars. J Oral Surg., v. 29, n. 2, p. 122-5, Feb, 1971.

44. NIH CONSENSUS DEVELOPMENT CONFERENCE FOR REMOVAL OF THIRD MOLARS. J Oral Maxillofac Surg., v. 38, n. 3, p. 235-6, Mar, 1980.

45. OLIVEIRA, M.G.; et al. Radiografia panorâmica na complementação diagnóstica de inclusões de terceiros molares. Rev Odonto Ciência., v. 11, n. 22, p. 83-91, Dez, 1996.

46. OSBORN, T.P; et al. A prospective study of complications related to mandibular third molar surgery. J Oral Maxillofac Surg., v. 43, n. 9, p. 767-69, Sep, 1985.

47. PATEL, J.R.; MASON-HING, L.R. The horizontal plane in patient positioning for panoramic radiography. Oral Surg., v. 62, n. 3, p. 350-3, Sep., 1986. 
48. PETERSON, L.J. Rationale for removing impacted teeth: When to extract or not to extract. J Am Dent Assoc., v. 123, n. 7, p. 198204, Jul, 1992.

49. PETERSON, L.J. Normas de Conduta em Dentes Impactados. In: PETERSON, L. J. et al. Cirurgia Oral e Maxilofacial Contemporânea, Rio de Janeiro, Guanabara-Koogan, 3. ed., 2000, Cap. 9, p. 214-47.

50. PETERSON, L.J. Prevenção e Tratamento das Complicações Cirúrgicas. In: PETERSON, L.J. et al. Cirurgia Oral e Maxilofacial Contemporânea, Rio de Janeiro, Ed. GuanabaraKoogan, 3. ed., 2000 Cap. 11, p. 256-273.

51. PHILLIPS, R.W. Elastômeros para moldagem. In: Skinner

- Materiais Dentários. Rio de Janeiro, Guanabara-Koogan , 9.ed 1993, Cap. 9, p. 77-90.

52. PINZAN, C.R.M.; SANT’ANA, E.; FERREIRA JR., O . Avaliação da Frequiência da Posição dos Terceiros Molares Inferiores Não Irrompidos na Clínica de Cirurgia da Faculdade de Odontologia de Bauru - USP. Monografia Apresentada ao P.E.T. (CAPES), como requisito para conclusão do Programa. Bauru 1999. 
53. POGREL, M.A. Complications of Third Molar Surgery. In: KABAN, L.B.; POGREL, M.A.; PERROT, D.H. Complications in Oral and Maxillofacial Surgery, Philadelphia, W. B. Saunders Co., 1997, Cap. 5, p. 59-66.

54. REJEBIAN, G.P. A statistical correlation of individual tooth size distortions on the orthopantomographic radiograph. Am J Orthod., v. 75, n. 5, p. 525-34, May, 1979.

55. RICHARDSON, M. Pre-eruptive movements of the mandibular third molar. Angle Orthod., v. 48, n. 3, p. 187-93, Jul, 1978.

56. RICHARDSON, M. Changes in lower third molars position in the young adult. Am J Orthod Dentofac Orthop., v. 102, n.4, p. 32027, Oct, 1992.

57. SAMAWI, S.S.B.; BURKE, P.H. Angular distortion in the orthopantomogram. Br J Orthod., v. 11, n. 2, p. 100-7, Apr, 1984.

58. SÄMFORS, K.A.; WELANDER, U. Distortion in the pantomogram due to object movement. Svensk. Tandlak.-t., v. 65 , n. 4, p. 21115, Apr. 1972.

59. SANTAMARIA, J.; ARTEAGOITIA, I. Radiologic variables of clinical significance in the extraction of impacted third molars. Oral Surg Oral Med Oral Pathol., v.84, n. 5, p. 469-73, Nov, 1997. 
60. SCHIFF, T.; et al. Commun positioning and technical errors in panoramic radiography. J Am Dent Assoc., v. 113, n.3, p. 422-6, Sep, 1986.

61. SERMAN, N.J.; BUCH, B. Localization of impacted teeth utilizing inherent panoramic distortions. Ann Dent., v. 51, n. 1, p. 8-10, summer, 1992.

62. SHILLER, W.R. Positional changes in mesio-angular impacted mandibular third molars during a year. J Am Dent Assoc., v. 99, n. 3, p. 460-4, Sep, 1979.

63. STAGGERS, J.A.; GERMANE, N.; FORTSON, W.M. A comparison of the effects of first premolar extractions on third molar angulation. Angle Orthod., v. 62, n. 2, p. 135-8, 1992.

64. STANLEY, H.R.; et al. Pathological sequelae of "neglected" impacted third molars. J Oral Pathol., v. 17, n.3, p. 113-17, Mar, 1988.

65. SWERIN, I.P. Radiology in the management of impacted teeth. Int Dent J., v. 37; n. 1, p. 25-30, Mar, 1987.

66. TAIT, R.V. Further observations on lower third molar tilt. Br J Orthod., v. 11, n. 4, p. 200-4, Oct, 1984. 
67. TEN CATE, A.R.. Erupção Dentária. In: _ BHASKAR, S. N. Histologia e Embriologia Oral de Orban. 10 ed. São Paulo: Ed. Artes médicas, 1989, Cap. 11, p. 389 - 405.

68. TRONJE, G. Image distortion in rotational panoramic radiography. V. Object morphology: inner structures. Acta Radiol Diagn., v. 23, n. 1, p. 59-62, Jan. 1982.

69. UPEDEGRAVE, W.J. The role of panoramic radiography in diagnosis. Oral Surg., v.22, n. 1, p. 49-57, July, 1966.

70. VALLE, A.L. Moldagem e Modelo de Trabalho. In: PEGORARO, L.F. Prótese Fixa. São Paulo, Artes Médicas: EAP-APCD, 1998. Cap 7, p. 149-74.

71. VENTÄ, H. M.; et al. Assessing the eruption of lower third molars on the basis of radiographic features. Br J Oral Maxillofac Surg., v. 29, n. 4, p. 259-62, Aug, 1991.

72. VENTÄ, I.; TURTOLA, L.; YLIPAAVALNIEMI, P. Change in clinical status of third molars in adults during 12 years of observation. J Oral Maxillofac Surg., v. 57, n. 4, p. 386-91, Apr, 1999. 
73. VON WOWERN, N.; NIELSEN, H.O. The fate of impacted lower third molars after the age of 20: a four-year clinical follow-up. Int J Oral Maxillofac Surg., v. 18, n. 5, p. 277-80, Oct, 1989.

74. WELANDER, U.; TRONJE, G.; McDAVID, W.D. Theory of rotational panoramic radiography. In: LANGLAND, O. E. et al. Panoramic Radiology. Philadelphia, Lea \& Febiger, 2.ed., 1989, Cap. 2, p. 38-75.

75. WESTESSON, P.; CARLSSON, L. anatomy of mandibular third molars: a comparison between radiographic appearance and clinical observation. Oral Surg Oral Med Oral Pathol., v. 49, n. 1, p. 904, Jan, 1980.

76. WINTER, G.B. Impacted third molars, St. Louis, Amer. Med. Book Co., 1926. 
ABSTRACT 


\section{9 - ABSTRACT}

The quality of the radiographic image is of fundamental importance in the surgical planning of the unnerupted teeth.

The panoramic x-ray is, doubtless, the most used, because it allows the visualization of the maxillary and the jaw in a single image, exposing the patient to small radiation doses. However this technique results in images with small distortion and decrease from the inherent details to the development image process.

The objective of this study was to evaluate the distortion in the position of the inferior third molars, according to the WINTER's classification, in the panoramic x-rays produced by the Rotograph Plus ${ }^{\mathrm{TM}}$ comparing them with the plaster models measurements, obtained in the patients' trans-surgical molding.

The study was performed form the panoramic xrays of 15 patients with exodontic indication; during the surgeries it was accomplished 
moldings with addition silicon, after the surgical exposition of the crown of the tooth to be extracted. The models were made using plaster type IV, obtaining 19 plaster models. After the measurement in panoramic radiographs and in the plaster models, we obtained the following results; there is average difference between the third molar position in the panoramic $\mathrm{x}$-ray and in the plaster model of $5,37^{\circ}$ (1,46 standard deviation, maximum value $9^{\circ}$ and minimum value $4^{\circ}$ ). In the Student "T" test it was verified a $p<0,05$ that the angle formed in the x-ray is larger than the one in the plaster models.

It is concluded that there is a considerable distortion in the teeth position, results that could change the surgical planning of the third molar exodontic, since that one of the indication for the tooth sectioning in the surgery is its inclination, but it doesn't discredit the panoramic x-ray as the main diagnostic and surgical planning of the unnerupted teeth. 